PRISCILA QUEIROZ GOUVEIA

\title{
Avaliação da infusão de vesículas extracelulares e células tronco mesenquimais derivadas de tecido adiposo em modelo experimental de fibrose peritoneal
}

\author{
Tese apresentada à Faculdade de Medicina da \\ Universidade de São Paulo para a obtenção do título de \\ Mestre em Ciências
}

Programa de Nefrologia

Orientadora: Profa. Dra. Irene de Lourdes Noronha

São Paulo 


\section{Dados Internacionais de Catalogação na Publicação (CIP)}

Preparada pela Biblioteca da

Faculdade de Medicina da Universidade de São Paulo

Creprodução autorizada pelo autor

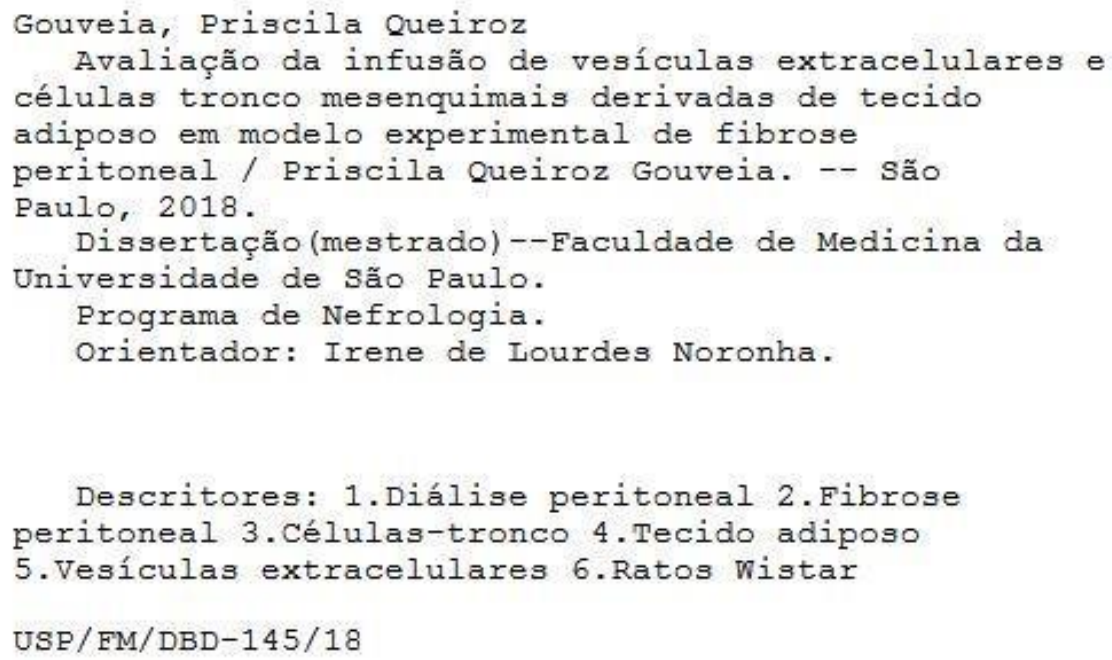

Responsável: Kátia Maria Bruno Ferreira - CRB-8/6008 
Este trabalho foi desenvolvido no Laboratório de Nefrologia Celular, Genética e Molecular - Laboratório de Investigação Médica 29, da Faculdade de Medicina da Universidade de São Paulo (FMUSP) e recebeu apoio financeiro da Coordenação de Aperfeiçoamento de Pessoal de Nível Superior (CAPES), auxílio n 1525477 


\section{AGRADECIMENTOS}

Várias pessoas contribuíram para a elaboração desse trabalho e a todos eles dedico minha gratidão.

À minha orientadora Prof. Dr- Irene Noronha, obrigada pela oportunidade oferecida, por todo apoio, tempo nas correções e dicas nas apresentações. Aprendi muito no laboratório

e no desenvolvimento deste trabalho. Admiro a sua dedicação como professora, pesquisadora e médica. Certamente, a senhora é uma influência na minha vida.

Ao meu pai Ariovaldo e minha mãe Luzia pela dedicação e apoio incondicional. Agradeço por terem me ensinado os verdadeiros valores da vida e por estarem sempre presentes. Todas as conquistas são por e para vocês.

Ao meu marido e namorado Marcelo, que deixa os meus dias mais calmos e felizes. Obrigada por fazer parte da minha vida e estar sempre presente de maneira prestativa, dedicada e paciente. Amo você!

A todos da minha família, em especial, meus irmãos Marcelo e Solange, pelo apoio e paciência.

À Cleonice, primeira pessoa que envie um email para uma vaga como biologista. Obrigada pela dedicação e carinho. Você é uma pessoa especial no laboratório, sempre disposta a ajudar e dar conselhos, além, é claro, de ser ótima companhia nos dias de happy hour. Adoro você Cleo. Muito obrigada por tudo! 
À Thalita, entramos juntas no laboratório e estamos terminando esta etapa juntas. Agradeço todas as dicas, ajuda e tudo que compartilhamos. Você é uma pessoa muito querida, obrigada pela amizade.

Ao Rafael, obrigada pela ajuda e amizade. Você é uma pessoa muito especial, fez toda diferença nestes anos de convivência. Obrigada Rafinha!

À Rita pelas risadas, ajuda na formatação e por compartilhar tudo conosco. Você é muito especial.

Aos amigos do LIM29, em especial, Margoth e Marcinha e que contribuíram muito para a elaboração deste trabalho. Camilla, Andreza, Felipe, Lucas, Marina, Mirella, José e Marcos agradeço por todos os momentos compartilhados. Aos amigos que não estão mais presentes, mas que fizeram parte dessa jornada Deise, Filipe, Alexandre, Justine, Gisele, Natália. Muito obrigada!

Aos doutores e amigos Samirah e Elerson, muito obrigada pelas risadas, discussões e apoio. Vocês são muito prestativos e gentis.

Ao Prof. Dr. Marcelo Moralles por ter me recebido em seu laboratório, onde tive o primeiro contato com as vesículas extracelulares.

À Prof. Dr ${ }^{\mathrm{a}}$ Lucia Andrade, por ter aberto as portas do seu laboratório, sem a ultracentrífuga esse trabalho não seria realizado. Muito obrigada. Camila e Talita obrigada por me acolherem tão bem no laboratório e pelas breves conversas científicas de corredor.

Ao prof. Dr. Raul Maranhão por ter me recebido em seu laboratório, permitindo o uso do aparelho para análise das vesículas extracelulares. 


\section{SUMÁRIO}

Lista de Figuras

Lista de Tabelas

Lista de Siglas

Lista de Símbolos

Resumo

Summary

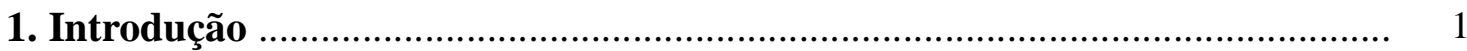

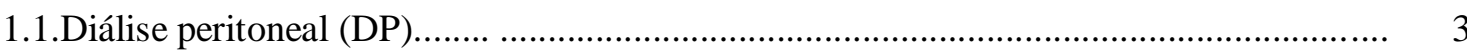

1.1.1 Inflamação e Neoangiogênese na DP),........................................................... 6

1.1.2. Fibrose Peritoneal (FP) )............................................................................... 8

1.1.3. Modelo Experimental de FibrosePeritoneal ...................................................... 9

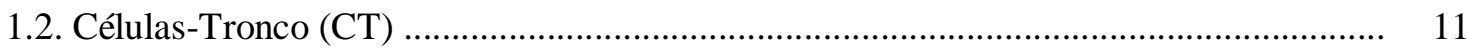

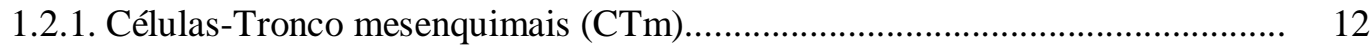

1.2.2. Células-Tronco mesenquimais de tecido adiposo (CTmTA) )........................... 13

1.3. Vesículas Extracelulares (VE) ..................................................................................... 15

1.3.1. Classificação de VE ........................................................................................ 17

1.3.2. Métodos de isolamento e caracterização de VE.................................................... 18

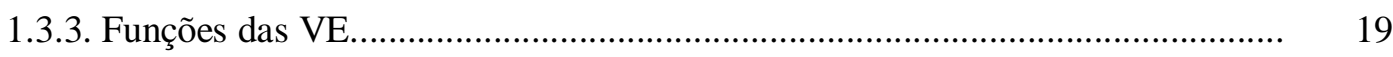

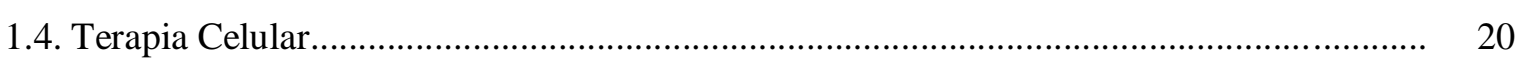

1.4.1.Potencial terapêutico das CTm .................................................................... 20

1.4.2. CTm na Fibrose Peritoneal ........................................................................... 21

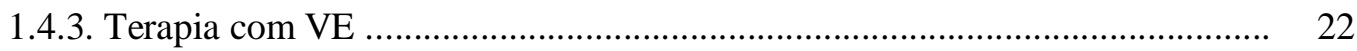

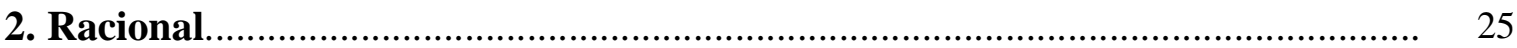

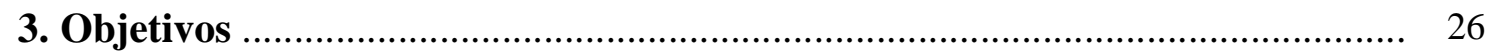

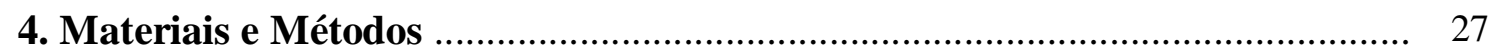

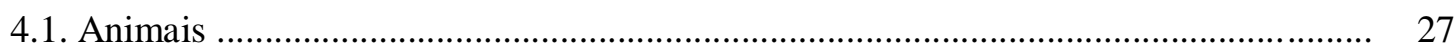

4.2. Modelo experimental de Fibrose Peritoneal …................................................................ 27

4.3. Isolamento e caracterização de CTmTA......................................................................... 27

4.3.1.Isolamento e cultivo de CTmTA .................................................................... 27

4.3.1.a). Isolamento.......................................................................... 27

4.3.1.b). Tripsinização................................................................................ 28

4.3.1.c). Cultivo e expansão...................................................................... 28

4.3.2.Caracterização de CTmTA ........................................................................... 29 
4.3.2.a). Citometria de fluxo.................................................................... 29

4.3.2.b). Diferenciação celular...................................................................... 30

4.4. Isolamento e caracterização de VE ........................................................................... 32

4.4.1. Isolamento de VE........................................................................................... 32

4.4.1. a). Cultivo e expansão das CTmTA..................................................... 32

4.4.1. b). Avaliação da viabilidade celular das CTmTA................................. 32

4.4.1. c). Isolamento por ultracentrifugação.................................................. 33

4.4.2.Caracterização e quantificação de VE................................................................... 33

4.4.2.a). Microscopia eletrônica....................................................................... 33

4.4.2.b). Análise de rastreamento das nanopartículas...................................... 34

4.4.2.c). Quantificação das proteínas totais..................................................... 34

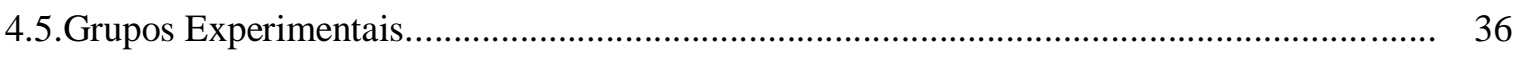

4.6. Análise da função peritoneal...................................................................................... 37

4.6.1. Ultracentrifugação (UF) ......................................................................... 37

4.6.2. Transporte de Solutos............................................................................... 37

4.7. Análise de Espessura da Membrana Peritoneal (MP) ..................................................... 38

4.7.1. Preparo do tecido .......................................................................................... 38

4.7.2. Análise histológica............................................................................................ 38

4.7.2.a). Colocaração de Tricrômio de Masson .............................................. 38

4.8. Análise do Infiltrado Celular na Membrana Peritoneal .................................................... 39

4.8.1. Imunohistoquímica...................................................................................... 39

4.8.1.a). Macrófagos, Linfócitos T e Miofibrobllastos ................................ 39

4.8.1.b). Quantificação de Macrófagos, Linfócitos T e Miofibroblastos........ 40

4.8.1.c). Densidade Vascular...................................................................... 41

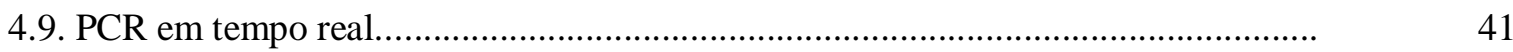

4.9.1. Extração de RNA......................................................................................... 41

4.9.2. Transcrição Reversa..........................................................................................

4.9.3. PCR em tempo real....................................................................................

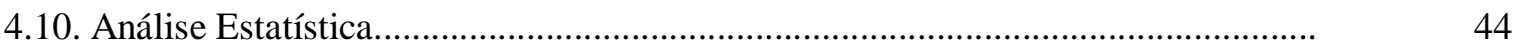

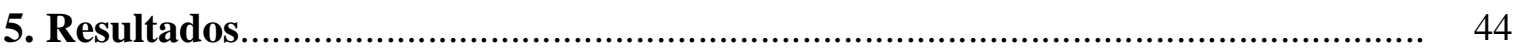

5.1. Isolamento e caracterização de CTmTA de ratos Wistar................................................. 46

5.1.1. Cultura de CTmTA........................................................................................ 46

5.1.2. Citometria de Fluxo - Imunofenótipo mesenquimal...................................... 47

5.1.3. Caracterização por Diferenciação Celular....................................................... 48

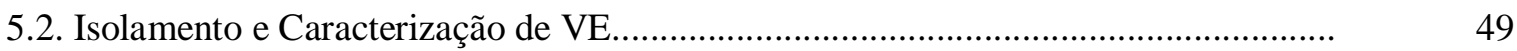


5.2.1. Isolamento de VE a partir de CTmTA..................................................... .. 49

5.2.2. Microscopia eletrônica de VE isoladas de CTmTA.............................................. 50

5.2.3. Análise da distribuição do tamanho das VE............................................... 51

5.2.4. Análise proteica das VE........................................................................ 52

5.3. Resultados dos Grupos Experimentais................................................................. 54

5.3.1. Mortalidade e evolução ponderal..............................................................

5.3.2. Fibrose Peritoneal................................................................................

5.3.3. Fibronectina.......................................................................................... 57

5.3.4. Miofibroblastos.................................................................................... 58

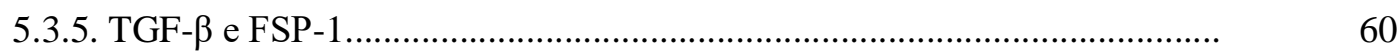

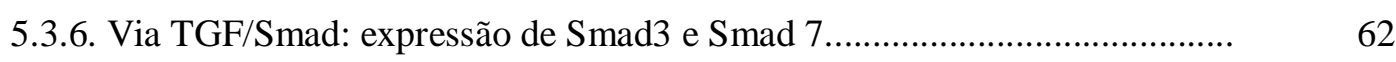

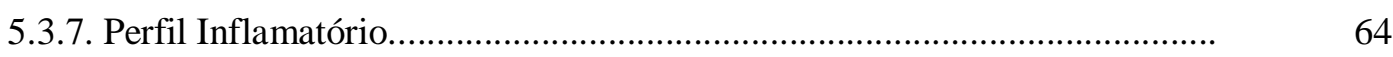

5.3.7.a).Macrófagos e linfócitos........................................................................... 64

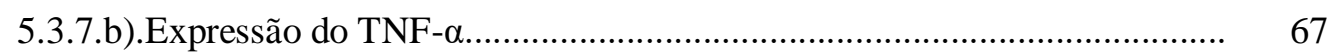

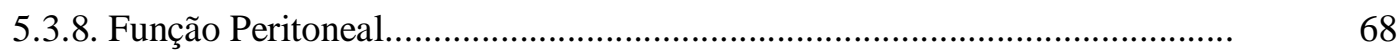

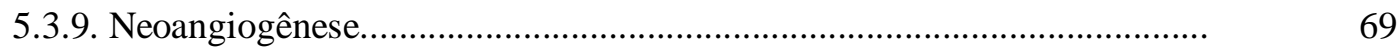

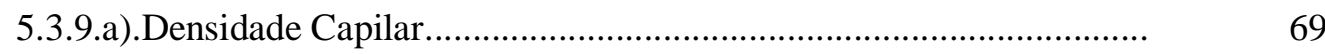

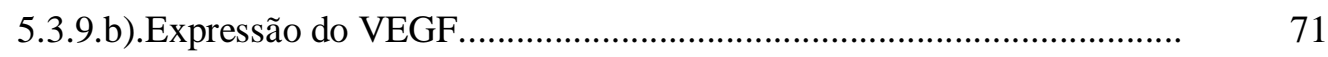

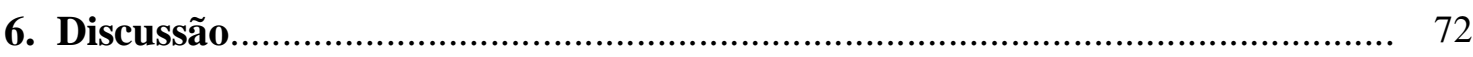

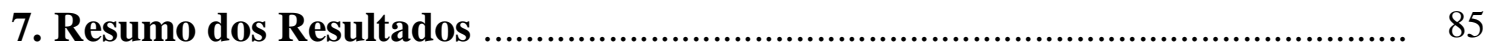

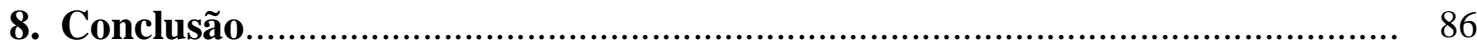

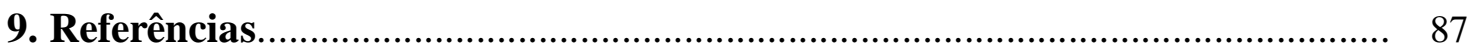




\section{Lista de figuras}

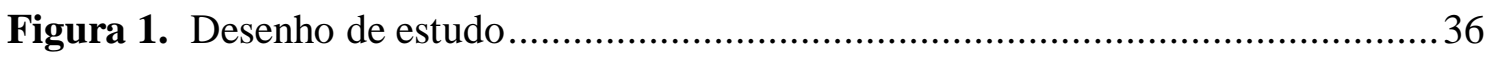

Figura 2. Imagem do cultivo celular de CTmTA de ratos Wistar............................. 46

Figura 3. Citometria de fluxo para caracterização do fenótipo mesenquimal das CTmTA em P4

Figura 4. Diferenciação in vitro das CTmTA na $4^{\mathrm{a}}$ passagem.................................. 48

Figura 5. Citometria de fluxo para detecção de células apoptóticas ..........................49

Figura 6. Análise da morfologia e tamanho das VE por microscopia eletrônica ...........50

Figura 7. Distribuição de tamanho das VE pelo método de rastreamento de nanopartículas

Figura 8. Distribuição de tamanho das VE pelo método de rastreamento de nanopartículas padronizado para tamanho e qualidade

Figura 9. Peso corpóreo médio dos animais dos grupos estudados

Figura 10. Fotomicrografias representativas de amostras de MP coradas com Tricrômio de Masson 56

Figura 11. Expressão gênica da Fibronectina na MP dos grupos estudados 57

Figura 12. Fotomicrografias representativas da imunohistoquímica para $\alpha-S M A$ na MP.

Figura 13. Expressão gênica do TGF- $\beta$ e do FSP-1 na MP

Figura 14. Expressão gênica de $\operatorname{Smad} 3$ e Smad7 na MP

Figura 15 Fotomicrografias representativas da imunohistoquímica para macrófagos (ED-1)

Figura 16. Fotomicrografias representativas da imunohistoquímica para linfócitos (CD43) .66

Figura 17. Expressão do gene pró-inflamatório TNF- $\alpha$ na MP. .67 
Figura 18. Ultrafiltração na MP dos grupos estudados.

Figura 19. Densidade Capilar na MP 70

Figura 20. Níveis da expressão gênica do VEGF na MP 71 


\section{Lista de tabelas}

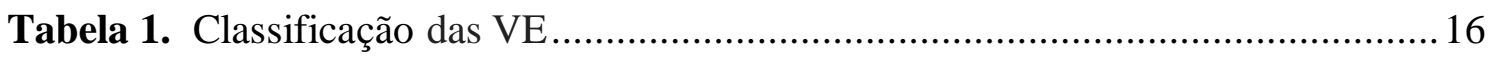

Tabela 2. Anticorpos utilizados para caracterização das CTmTA por citometria de

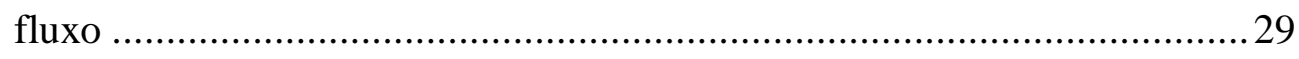

Tabela 3. Primers utilizados para os experimentos de PCR em tempo real ................ 44

Tabela 4. Análise proteica das VE obtidas das CTmTA ..........................................53

Tabela 5. Evolução ponderal dos grupos experimentais.........................................54

Tabela 6. Quantificação da espessura da MP ..................................................................55

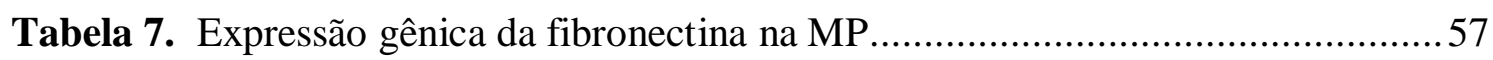

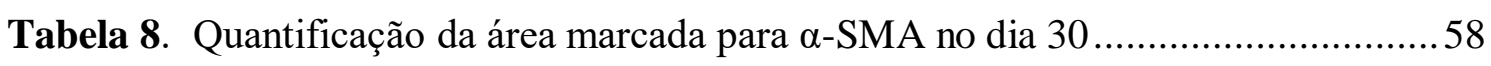

Tabela 9. Expressão gênica de TGF- $\beta$ e FSP-1 na MP ….................................................60

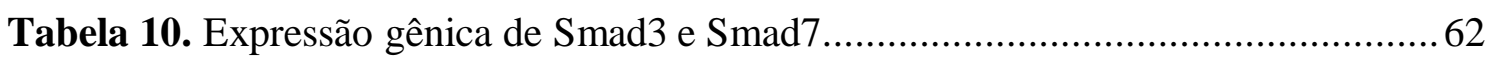

Tabela 11. Quantificação dos macrófagos e linfócitos na MP .......................................64

Tabela 12. Expressão gênica da citocina pró-inflamatória TNF- $\alpha$ na MP .......................67

Tabela 13. Função Peritoneal em todos os grupos no dia 30 ....................................6 68

Tabela 14. Quantificação da densidade capilar (Isolectina-B4) no dia 30 ..................69

Tabela 15. Expressão gênica do VEGF na MP ................................................................72 


\section{Lista de Siglas}

\begin{tabular}{|c|c|}
\hline ALIX & ALG-2-Interacting Protein $X$ \\
\hline BSA & Albumina Sérica Bovina \\
\hline BMP & Bone-MorphogenicProtein \\
\hline cDNA & DNA complementar \\
\hline CT & Célula Tronco \\
\hline $\mathbf{C t}$ & Cycle treshold \\
\hline CMVs & Corpos Multivesiculares \\
\hline CTm & Células Tronco mesenquimais \\
\hline CTmMO & Células Tronco mesenquimais de Medula Óssea \\
\hline CTmTA & Células Tronco mesenquimais de Tecido Adiposo \\
\hline dATP & Desoxiadenosina Trifosfatada \\
\hline dCTP & Desoxicitidina Trifosfatada, \\
\hline dGTP & Desoxiguanosina Trifosfatada \\
\hline dTTP & Desoxitimidina Trifosfatada \\
\hline dNTP & Desoxirribonucleotídeos Trifosfatados \\
\hline DAPI & 4,6-diamidino-2-fenilindol \\
\hline DLS & Dyinamic Ligh Scattering \\
\hline $\mathbf{D M}$ & Diabetes Mellitus \\
\hline DMEM-Low & Meio de Eagle Modificado por Dubelco-baixa concentração de glicose \\
\hline DNA & Ácido Desoxirribonucleico \\
\hline DP & Diálise Peritoneal \\
\hline DRC & Doença Renal Crônica \\
\hline EMT & Epithelial-Mesenchymal Transition \\
\hline ESCRT & Endosomal Sorting Complexes Required for Transport \\
\hline FITC & Isotiocianato de Fluoresceína \\
\hline FSP-1 & Fibroblast Specific Protein-1 \\
\hline $\mathbf{F P}$ & Fibrose Peritoneal \\
\hline GC & Gluconato de Clorexidina \\
\hline HGF & Hepatocyte Growth Factor \\
\hline IGF-1 & Insulin Growth Factor 1 \\
\hline
\end{tabular}




\begin{tabular}{|c|c|}
\hline IL-10 & Interleucina 10 \\
\hline IL-12 & Interleucina 12 \\
\hline IL-1及 & Interleucina $1 \beta$ \\
\hline IL-6 & Interleucina 6 \\
\hline INF- $\gamma$ & Interferon-gamma \\
\hline IP & Intraperitoneal \\
\hline KCL & Cloreto de Potássio \\
\hline ISEV & Internacional Society for Extracellular Vesicles \\
\hline LSAB-AP & Labeled Streptavidin-Biotin Alcaline Phosphatase \\
\hline MCP-1 & Monocyte Chemoattractant Protein-1 \\
\hline ME & Microscopia Eletrônica de Transmissão \\
\hline $\mathbf{M g C l}_{2}$ & Cloreto de Magnésio \\
\hline M-MLV & Moloney Murine Leukemia Virus \\
\hline MP & Membrana Peritoneal \\
\hline $\mathrm{NaCl}$ & Cloreto de Sódio \\
\hline NF-kB & Nuclear Factor Kappa-B \\
\hline NK & Natural killer cell \\
\hline NTA & Análise de Rastreamento de Nanopartículas \\
\hline OD & Densidade Ótica \\
\hline TRPS & Tunable Resistive Pulse Sensing \\
\hline PBS & Tampão Fosfato-NaCl \\
\hline PCR & Reação em Cadeia de Polimerase \\
\hline PDGF & Platelet-Derived Growth Factor \\
\hline PE & Ficoeritrina \\
\hline PE-Cy5.5 & Ficoeritrina Cy5.5 \\
\hline PET & Teste de Equilíbrio Peritoneal \\
\hline pH & Potencial de Hidrogênico \\
\hline RNA & Ácido Ribonucleico \\
\hline RNAm & RNA mensageiro \\
\hline rpm & rotações por minuto \\
\hline SDF-1 & Stromal Cell-Derived Factor 1 \\
\hline SF & Solução Fisiológica \\
\hline SFB & Soro Fetal Bovino \\
\hline
\end{tabular}


SMA

TBS

TGF- $\beta$

TGS101

TNF- $\alpha$

Tris

UF

VE

VEGF
Smooth Muscle Actin

Tampão Tris- $\mathrm{NaCl}$

Transforming Growth Factor beta

Tumor Susceptibility Gene 101

Tumor Necrosis Factor-alfa

Hidroximetil(amino)Metano

Ultrafiltração

Vesículas Extracelulares

Vascular Endothelial Growthf Actor 


\section{Lista de símbolos}

\begin{tabular}{ll}
$\mathbf{c e ́ l} / \mathbf{m m}^{2}$ & Células por milímetro quadrado \\
$\mathbf{c m}^{2}$ & Centímetro quadrado \\
$\mathbf{d L}$ & decilitro \\
$\boldsymbol{\Delta}$ & Delta \\
$\mathbf{X} \mathbf{g}$ & força de gravidade \\
$\mathbf{g}$ & Grama \\
${ }^{\circ} \mathbf{C}$ & Graus centígrados \\
$\mathbf{K g}$ & Kilograma \\
$\mathbf{L}$ & Litro \\
$\boldsymbol{\mu}$ & Micro \\
$\mathbf{\mu g}$ & Micrograma \\
$\boldsymbol{\mu L}$ & Microlitro \\
$\mathbf{m g}$ & Miligrama \\
$\mathbf{m L}$ & Mililitro \\
$\mathbf{m M}$ & Milimolar \\
$\mathbf{M}$ & Molar \\
$\mathbf{n M}$ & Nanomolar \\
$\mathbf{n m}$ & nanômetro \\
$\boldsymbol{\%}$ & Porcentagem \\
$\mathbf{U}$ & Unidades \\
$\boldsymbol{v} \mathbf{W}$ & Versus \\
$\mathbf{W}$ & watts \\
\hline
\end{tabular}




\section{RESUMO}

Gouveia PQ. Avaliação da infusão de vesículas extracelulares e células tronco mesenquimais derivadas de tecido adiposo em modelo experimental de fibrose peritoneal [dissertação]. São Paulo: Faculdade de Medicina, Universidade de São Paulo; 2018.

Em pacientes submetidos à diálise peritoneal (DP), alterações morfofuncionais da membrana peritoneal (MP) ocorrem de forma progressiva ao longo dos anos. Estas alterações caracterizam-se, morfologicamente, por perda da camada mesotelial, inflamação, neoangiogênese e fibrose peritoneal (FP) e, funcionalmente, pela queda na ultrafiltração. Tais alterações implicam diretamente em perda da eficiência dessa terapia renal substitutiva. Até o momento, não existe tratamento específico capaz de prevenir ou reverter esta situação. As células tronco mesenquimais (CTm) têm mostrado efeitos terapêuticos benéficos em doenças associadas à fibrose. A participação das CTm no reparo tecidual está principalmente relacionada à sua atividade parácrina, através da liberação de fatores solúveis e vesículas extracelulares (VE). As VE liberadas são importantes na intercomunicação célula-célula e possivelmente contribuem para o efeito terapêutico das CTm ao entregar seu conteúdo (mRNAs, miRNAs, proteínas) para as células alvo. Assim, o objetivo central do presente estudo foi comparar o possível efeito terapêutico das CTm de tecido adiposo (CTmTA) e de VE derivadas de CTmTA na prevenção da FP experimental em ratos. A FP foi induzida em ratos Wistar machos através de injeções intraperitoneais (IP) de gluconato de clorexidina (GC) a 0,1\%, em dias alternados, por um período de 30 dias. As CTmTA utilizadas foram obtidas de tecido adiposo gonadal de rato Wistar, cultivadas e expandidas até a $4^{\text {a }}$ passagem e caracterizadas de acordo com a sua capacidade de aderência ao plástico, presença de marcadores de superfície e pela diferenciação celular in vitro. As VE derivadas de CTmTA foram isoladas por ultracentrifugação. Os protocolos de isolamento por ultracentrifugação e caracterização por microscopia eletrônica, rastreamento de nanopartículas e quantificação das proteínas totais das VE foram padronizados e estabelecidos no laboratório. Os tratamentos com 2x10 ${ }^{6} \mathrm{CTmTA}$ ou com $30 \mu \mathrm{g}$ VE foram administrados por injeções de IP. Os animais do estudo foram divididos em 4 
grupos: Grupo Controle ( $\mathrm{n}=8$ ), animais que receberam apenas injeções IP de solução fisiológica; Grupo FP $(n=9)$, animais que receberam injeções IP de GC para indução da FP e foram tratados com solução fisiológica; Grupo FP + CTmTA $(n=8)$, animais que receberam injeções IP de GC para indução da PF e foram tratados com $2 \times 10^{6} \mathrm{CTmTA}$, no $3^{\circ}$ e $10^{\circ}$ dias, via IP, e Grupo FP + VE $(n=8)$, animais que receberam injeções IP de GC para indução da FP e foram tratados com $30 \mu \mathrm{g}$ de VE, IP no $3^{\circ}$ e $10^{\circ}$ dias, via IP. Após 30 dias da indução de FP, os animais foram submetidos ao teste de função peritoneal e, em seguida, à eutanásia para coleta de amostras de tecido do peritôneo. As amostras do peritôneo parietal foram direcionadas para análises histológicas, imunohistoquímicas, de imunofluorescência e biologia molecular. No Grupo FP, como esperado, houve um aumento significativo da espessura da MP. Os tratamentos com CTmTA e VE preveniram o espessamento da MP, mantendo a espessura similar à do Grupo Controle. Os tratamentos com CTmTA e VE bloquearam o aumento do número de miofibroblastos, da expressão de fibronectina e de fatores envolvidos na FP (TGF- $\beta$ e FSP-1), observados nos animais do Grupo FP. Além disso, a expressão gênica de Smad3, que está associada à ativação de genes pró-fibróticos, estava aumentada no Grupo FP e foi reduzida nos grupos tratados. Por outro lado, a expressão gênica de Smad7, um gene associado à contrarregulação do TGF- $\beta$, estava reduzida no Grupo FP e foi aumentada nos grupos que receberam tratamento. Os tratamentos com CTmTA e VE também apresentaram efeitos anti-inflamatórios, reduzindo o número de macrófagos e de linfócitos na MP e diminuindo a expressão do TNF- $\alpha$, uma citocina pró-inflamatória, quando comparados ao Grupo FP. Com relação a análise funcional, o grupo tratado com VE apresentou melhora na capacidade de ultrafiltração. No entanto, os tratamentos com CTmTA e VE não alteraram o transporte de glicose pela MP em relação ao Grupo FP. Outro aspecto dos efeitos dos tratamentos CTmTA e VE diz respeito à neoangiogênese na MP, importante fator relacionado a capacidade de ultrafiltração. Apesar dos grupos tratados com CTmTA e VE apresentarem diminuição significativa da expressão de VEGF na MP, não foi constatada diferença na densidade capilar na MP destes grupos, em relação ao Grupo FP. Em conclusão, no modelo experimental de FP, os tratamentos com CTmTA e VE apresentaram efeito anti-inflamatório e foram igualmente eficientes no bloqueio do processo de FP. O tratamento com VE mostrou melhor capacidade de preservação da função peritoneal, com aumento da capacidade de ultrafiltração. Portanto, os 
tratamentos com CTmTA ou com VE derivadas de CTmTA apresentam potencial terapêutico e constituem uma nova abordagem, ainda pouco explorada, na prevenção do desenvolvimento da FP associada à DP.

Descritores: diálise peritoneal; fibrose peritoneal; células-tronco; tecido adiposo; vesículas extracelulares; ratos Wistar. 


\section{SUMMARY}

Gouveia PQ. Evaluation of the infusion of extracellular vesicles and mesenchymal stem cells derived from adipose tissue in an experimental model of peritoneal fibrosis [dissertation]. São Paulo: "Faculdade de Medicina, Universidade de São Paulo"; 2018.

In patients undergoing peritoneal dialysis (PD), morphofunctional changes of the peritoneal membrane (PM) occur progressively over the years. These modifications are morphologically characterized by loss of the mesothelial layer, inflammation, neoangiogenesis and peritoneal fibrosis $(\mathrm{PF})$, and functionally, by the reduction in ultrafiltration (UF). Moreover, these changes directly imply in failure of treatment. Currently, there is no clinical alternative to prevent or reverse this situation. In this context, mesenchymal stem cells (MSC) have shown beneficial therapeutic effects in diseases associated with fibrosis. The participation of MSC in tissue repair is related to their paracrine activity, through the release of soluble factors and extracellular vesicles (EV). The EV released are important to cell-to-cell communication and the possibility to contribute to the therapeutic effect of MSC, by delivering their content (mRNAs, miRNAs, proteins) to the target cells. Therefore, the aim of this study was to compare the possible therapeutic effect of MSC versus EV derived from MSC for prevention of experimental PF fibrosis in rats. PF was induced in male Wistar rats by intraperitoneal (IP) injections of $0.1 \%$ chlorhexidine gluconate (CG) on alternate days, for a period of 30 days. The MSC used were obtained from Wistar rats gonadal adipose tissue (ASC), cultured and expanded to the $4^{\text {th }}$ passage and characterized according to their ability to adhere to plastic, presence of membranes markers and by cell differentiation in vitro. EV derived from ASC were isolated by ultracentrifugation. The protocols of ultracentrifugation and characterization by electron microscopy, nanoparticle tracking and quantification of total proteins from EV were standardized and established in the laboratory. Both treatments using ASC ( $2 \times 10^{6}$ cells) or EV $(30 \mu \mathrm{g})$ were administered via IP injections. The animals were divided into four groups: Control group $(n=8)$, animals that received only IP injections of physiological solution; PF group $(n=9)$, animals that received IP injections of CG to induce PF and were treated with physiological solution; $\mathbf{P F}+\mathbf{A S C}$ group $(\mathrm{n}=8)$, animals that received IP injections of 
CG for induction of PF and were treated with $2 \times 10^{6}$ ASC, at the $3^{\text {rd }}$ and $10^{\text {th }}$ day, by IP delivery; PF+EV group ( $\mathrm{n}=8)$, animals that received IP injections of CG for induction of PF and were treated with $30 \mu \mathrm{g}$ of EV at the $3^{\text {rd }}$ and $10^{\text {th }}$ day, by IP delivery. After 30 days of PF induction, the animals were submitted to the peritoneal function test and then, to euthanasia to collect tissue samples from the peritoneum. The samples were analyzed by histology immunohistochemistry, immunofluorescence, and also by molecular biology. In the FP group, there was a significant increase in the thickness of the PM. Both treatments with ASC or EV prevented increase in PM thickness. Importantly, ASC and EV treatments blocked the increased number of myofibroblast, fibronectin expression and the factors involved in PF (TGF- $\beta$ and FSP-1) observed in the PF group. In addition, the Smad3 gene expression, which is associated with activation of pro-fibrotic genes, was increased in the PF group and decreased in the treatments groups. Conversely, the gene expression of Smad7, a gene associated with TGF- $\beta$ against regulation, was decreased in the PF group and increased in the animals that received the treatment. ASC and EV injections also showed anti-inflammatory effects, reducing the infiltration of macrophages and lymphocytes into the PM and decreasing the expression of TNF- $\alpha$, a proinflammatory cytokine. The treatments with ASC and EV did not alter the glucose transport by the PM in relation to the PF group, but promoting an increase of the UF capacity. Only the EV treated group showed an increase in UF capacity. Another aspect of the effects of ASC and EV treatments concerns to neoangiogenesis in the PM, an important factor related to the UF capacity. Although the treated groups showed a significant decrease of the VEGF expression in the PM, no difference in the capillary density was observed in relation of PF group. In conclusion, in the experimental model of FP, treatement with ASC or EV showed anti- inflammatory effects and were equally efficient in blocking the PF process. However, the treatment with EV showed a better capacity of preservation of the peritoneal function, with increased capacity of UF. Therefore, the use of ASC and EV potentially represents a new therapeutic approach in preventing the development of PF associated with PD.

Descriptors: peritoneal dialysis; peritoneal fibrosis; stem cells; adipose tissue; extracellular vesicles; rats, Wistar. 


\section{INTRODUÇÃO}

A doença renal crônica (DRC) é um grave problema de saúde pública no Brasil e no mundo (Noronha et al., 1997; El Nahas et al., 2005; Couser et al., 2011; El Cordeiro et al., 2013). Classificada como a perda progressiva e irreversível da função renal, as causas mais comuns são hipertensão arterial sistêmica, diabetes mellitus (DM) e glomerulonefrites (K/DOQI, 2002). Com a evolução da DRC para o estágio 5, os pacientes necessitam de terapia de substituição renal, como hemodiálise, diálise peritoneal e transplante renal (Couser et al., 2011).

No Brasil, o número total estimado de pacientes em terapia dialítica vem aumentando sucessivamente. Ao longo dos anos, foram contabilizados 42.695 casos no ano de 2000, 92.091 em 2010 e 122.825 em 2016, com uma taxa de prevalência de 592 pacientes por milhão da população em 2016, de acordo com o Censo da Sociedade Brasileira de Nefrologia.

O percentual de pacientes realizando diálise peritoneal (DP) é menor quando comparado à hemodiálise. De acordo com os dados do censo da Sociedade Brasileira de Nefrologia em 2016, 92,1\% dos pacientes com DRC faziam hemodiálise e 7,9\% DP. O baixo número de pacientes em DP tem causas multifatoriais, como encaminhamento tardio ao nefrologista, desconhecimento do método, falta de condições sociais para receber o tratamento e motivos socioeconômicos (Finkelstein et al., 2006).

A DP é uma excelente alternativa de tratamento, pois permite maior autonomia e independência ao paciente, devido à possibilidade de fazer a terapia no domicílio. Além disso, evidências apontam para uma maior sobrevida dos pacientes submetidos à DP nos dois primeiros anos, além de menores taxas de hospitalizações e infecções (Ghaffari et al., 2013; Lukowsky et al., 2013; Kumar et al., 2014). Outro aspecto relevante é a 
preservação da função renal residual nesses pacientes, um determinante importante da sobrevida, com consequente melhor qualidade de vida (Termorshuizen et al., 2003; Lamiere et al., 2005).

Um dos problemas no tratamento da DP é a falha da técnica, seja por peritonite, por dificuldade na adequação ou por falência da membrana peritoneal (MP) (Finkelstein et al., 2006). Essas complicações caracterizam-se histologicamente por inflamação e fibrose MP levando à perda da capacidade de ultrafiltração (UF) (Devuyst et al 2010). Em casos mais graves e raros, ocorre uma resposta fibrogênica exacerbada da MP chamada peritonite esclerosante encapsulante, que está associada a altos índices de mortalidade (Cestari et al., 2013).

O tratamento desta condição clínica é limitado, levando na maioria dos casos à conversão para hemodiálise. Estratégias terapêuticas que previnam ou bloqueiem a progressão dessas complicações no tratamento da DP são importantes. O tratamento com corticoide tem sido empregado, porém com pouco sucesso. Mais recentemente, o tamoxifeno foi utilizado no tratamento de casos de peritonite esclerosante encapsulante e na regressão da fibrose retroperitoneal idiopática (Clarck et al., 1991; Allaria et al., 1999; Guest et al., 2009). O desenvolvimento de novas terapias anti-fibróticas pode trazer grandes benefícios na qualidade de vida dos pacientes dialíticos, atenuando a progressão da fibrose e os subsequentes danos ao longo do tratamento (Yu et al., 2014).

A terapia com CT mesenquimais (CTm) está entre as possíveis alternativas de tratamento. Sua utilização tem um duplo potencial terapêutico: de um lado, as CTm possuem propriedades tróficas promissoras no reparo dos tecidos, com resultados positivos na modulação de vias inflamatórias, reparadoras, fibróticas e angiogênicas (Makridakis et al., 2013); de outro, produtos secretados pelas CTm conhecidos como vesículas extracelulares (VE) - podem exercer propriedades regenerativas importantes 
no reparo tecidual, pela a sua capacidade de intercomunicação célula-célula e seus efeitos terapêuticos na regeneração dos tecidos (Miyahara et al., 2006; Yu et al., 2014).

Nesse sentido, objetivo central do presente estudo foi comparar o possível efeito terapêutico da administração da CTmTA ou de VE derivadas de CTmTA na prevenção da fibrose peritoneal (FP) experimental em ratos.

\subsection{Diálise Peritoneal (DP)}

O termo diálise implica no transporte de água e solutos através de uma membrana semipermeável. Esta pode ser de dois tipos: artificial ou biológica. No primeiro caso temos, por exemplo, membranas utilizadas na hemodiálise. No segundo caso temos o peritôneo utilizado na DP (Abensur et al., 2005). Na DP é o próprio peritôneo que estabelece a interface entre o sangue do paciente e o dialisato, permitindo a troca de solutos (Schilte et al., 2009).

O peritôneo é uma membrana serosa que reveste as cavidades abdominal e pélvica (peritôneo parietal) e os órgãos viscerais (peritôneo visceral). Considera-se que a área de superficial total da MP aproxima-se da superfície corporal. A MP é composta pelo mesotélio, pela lâmina basal e pela camada submesotelial. O mesotélio consiste de uma monocamada de células epiteliais anexada à lâmina basal. A camada submesotelial é uma estrutura de apoio das camadas anteriores e contém fibras de colágeno, fibronectina, proteoglicanos, raros fibroblastos, adipócitos, vasos linfáticos e sanguíneos e matriz extracelular (Devuyst et al., 2010; van Baal et al., 2017).

O transporte peritoneal de solutos compreende três diferentes processos: difusão, UF e absorção de fluídos (Rippe et al., 1991; Abensur et al., 2005; Barros et al., 2006; Abensur et al., 2008). 
A difusão é definida como a troca de solutos que ocorre naturalmente de acordo com o gradiente de concentração. Neste processo, os solutos em alta concentração no sangue (como a uréia, creatinina e potássio) passam através da MP para a solução de diálise a favor do seu gradiente de concentração. O lactato e o bicarbonato presentes na solução de diálise migram para a corrente sanguínea, corrigindo distúrbios ácido-base.

Na UF, o transporte de líquido ocorre por meio de um gradiente de pressão osmótica gerado pela glicose na solução de diálise. Neste processo, a água e os solutos passam do sangue para a cavidade abdominal através da MP. Ao atravessar a MP, a água carrega pequenas moléculas, uréia e creatinina. Finalmente, o processo de absorção de fluídos ocorre pela drenagem de solutos contidos na solução de diálise e em ritmo constante pelo sistema linfático.

Uma melhor compreensão do transporte peritoneal ocorreu com o desenvolvimento do "Modelo de Três Poros", elaborado para reproduzir matematicamente o comportamento da MP em relação à passagem de fluídos e solutos. Segundo este modelo, 3 poros de diferentes tamanhos regulam a passagem de moléculas pela MP:

- Os ultraporos (raio $<0,8 \mathrm{~nm}$ ) das células endoteliais dos capilares peritoneais, que são responsáveis pela permeabilidade e pelo transporte de água. Estes poros contêm proteínas da membrana celular endotelial, chamadas aquaporinas, que também estão presentes nos túbulos renais e hemácias.

- Os poros pequenos (raio de 4-6nm) estão presentes em grande quantidade. Em associação com a água são transportados por fendas intercelulares do endotélio, regulando a passagem dos pequenos solutos como ureia, creatinina, potássio e sódio.

- Os poros grandes (raio de 20-40nm), em menor número e distribuídos esparsamente, são responsáveis pelo transporte de macromoléculas como proteínas. 
Diversos parâmetros influenciam o transporte de solutos e água através da MP durante a DP, dentre eles está o número reduzido de todos os tipos de poros, com diminuição acentuada na permeabilidade para pequenos solutos, o aumento da absorção linfática e a redução seletiva do transporte de água transcelular (Devuyst et al., 2006; Krediet et al., 2016).

Na DP, os parâmetros de transporte da MP devem ser rotineiramente avaliados utilizando-se o teste de equilíbrio peritoneal (Peritoneal Equilibration Test - PET). Este método de avaliação funcional consiste na mensuração da taxa de transporte de pequenos solutos na DP. O transporte de solutos é classificado em quatro categorias: alto transportador, médio-alto transportador, médio-baixo transportador e baixo transportador. O PET orienta a prescrição da DP (Devuyst et al., 2010; Sampimon et al., 2014).

Alterações funcionais na MP estão associadas principalmente ao aumento da taxa de transporte peritoneal e à diminuição da UF. Qualquer aumento no transporte de pequenos solutos através da membrana causa uma rápida dissipação do gradiente osmótico (devido ao aumento da reabsorção de glicose) e uma perda de UF (Devuyst et al., 2006).

Pesquisas demonstram que pacientes submetidos à DP por tempo superior a dois anos tendem a evoluir com perda da capacidade de UF e, após cinco anos de tratamento, podem ter formação de FP que leva à uma redução da área efetiva da MP (Williams et al., 2002; Devuyst et al., 2006). 


\subsubsection{Inflamacão e Neoangiogênese na DP}

A permanência dos pacientes em DP é limitada por diversos fatores que causam alterações na MP levando ao espessamento, perda da camada mesotelial, inflamação, neoangiogênse e FP (Devuyst et al., 2010).

O processo inflamatório é desencadeado e modulado principalmente pelas soluções de diálise peritoneal bioincompatíveis. As soluções de DP são consideradas biocompatíveis pela sua hipertonicidade, baixo $\mathrm{pH}$, elevada concentração de glicose e produtos de degradação. Este último elemento merece destaque, uma vez que a exposição a produtos de degradação da glicose e a formação de produtos de glicação avançada (AGEs) que levam ao aumento do dano citotóxico e a respostas proinflamatórias nas células mesoteliais, estimulando a produção do fator de crescimento endotelial vascular (VEGF) (Witowski et al., 2001; Lai et al., 2010).

Outros fatores extrínsecos contribuem para a inflamação como uremia e peritonite. A uremia também é considerada uma causa extrínseca de FP e um fator agressor. Aumento da espessura da MP em pacientes com DRC, quando comparado à de indivíduos saudáveis, foi detectado mesmo antes do início da diálise, indicando que a uremia induz inflamação no peritôneo. Episódios de peritonite induzem a infiltração de células inflamatórias, inicialmente por neutrófilos e, subsequentemente, por macrófagos. Estas alterações inflamatórias podem causar aumento na permeabilidade da MP e consequente intensificação do processo de transporte peritoneal, progredindo para a falência da UF (Topley et al., 1996; Williams et al., 2002; Lai et al., 2010).

Os fatores intrínsecos ao processo inflamatório estão relacionados a alterações na própria MP em diferentes níveis. No mesotélio, a inflamação local e o estresse oxidativo resultam na lesão peritoneal contínua, acelerando a transição epitéliomesenquimal (EMT) das células mesoteliais (Yáñez-Mó et al., 2003). Além disso, pode 
haver um desprendimento e perda da superfície mesotelial, iniciando o processo de FP (Yáñez-Mó et al., 2003; Zhou et al., 2016). Na membrana basal ocorre o espessamento da membrana basal submesotelial com um aumento desproporcional da matriz extracelular e de fibroblastos. Neste caso, a MP sofre os efeitos das soluções de glicose utilizadas na DP, resultando em neoangiogênse, que é mediada pela indução de citocinas inflamatórias, fatores de crescimento como interleucina-6, fator de transformação do crescimento beta (TGF- $\beta$ ) e VEGF, que causam aumento da permeabilidade da membrana. No sistema vascular, ocorre a vasculopatia hializante com a reduplicação da membrana basal subendotelial. Este processo leva ao aumento no número de vasos proporcionando aumento na superfície de troca do peritôneo, à rápida absorção do agente osmótico e à dissipação precoce do gradiente osmolar, levando ao declínio funcional da MP (Abensur et al., 2005; Lai et al., 2010).

Neoangiogênese, inflamação e FP parecem estar intimamente relacionados, a análise de biópsias peritoneais de pacientes em DP tem demonstrado um aumento do número de vasos associado às alterações fibróticas (Mateijsen et al., 1999; Witowski et al., 2001).

\subsubsection{Fibrose Peritoneal}

Definido como um acúmulo anormal de componentes da matriz extracelular, a fibrose é o ponto final de muitas doenças inflamatórias crônicas (Krediet et al., 1997).

Apesar de sua progressão lenta, o processo de FP é capaz de afetar vários tecidos levando à perda funcional. Como exposto anteriormente, fatores envolvidos no processo inflamatório - intrínsecos e extrínsecos - estão relacionados ao desenvolvimento da FP.

O espessamento da matriz extracelular submesotelial tem sido interpretado na última década como consequência da transformação das células mesoteliais em células 
fibroblastóides (miofibroblastos), que são reguladas pelo TGF- $\beta$. A transdiferenciação das células mesoteliais ocorre quando elas passam a se comportar como células mesenquimais ativadas e migram para a camada submesotelial, num processo de EMT (Yáñez-mó et al., 2003). Tantos as células mesoteliais quanto os miofibroblastos sintetizam citocinas pró-inflamatórias (TNF- $\alpha$, IL-1 $\beta$ e MCP-1) e fatores angiogênicos como o VEGF (Moinuddin et al., 2014). A longo prazo, a expressão aumentada do VEGF pode ser detectada no dialisato de pacientes em DP e está associado a permeabilidade de pequenos solutos e perda da UF (Pecoits- filho et al 2002; Pletinck et al., 2012). Os miofibroblastos que migram se estabelecem na MP e devido à expressão de citocinas e fatores de crescimento produzem colágeno e fibronectina, dessa forma induzem a FP (Pecoits-Filho et al., 2002; Zhou et al., 2016).

Agentes presentes nas soluções de DP - produtos da glicose e degradação da glicose - estimulam a produção de TGF- $\beta$ e VEGF. Estes dois mediadores pertencem às principais vias que podem levar à FP (Abensur et al., 2005).

O TGF- $\beta$ é classicamente conhecido por sua contribuição à progressão da lesão pela expansão da matriz extracelular e fibrose tecidual. Pertencem à superfamília TGF$\beta$ composta por três isoformas homólogas, TGF $\beta 1$, TGF- $\beta 2$ e TGF- $\beta 3$, além de outras proteínas de sinalização como Bone Morphogenic Protein (BMP) e ativinas. O TGF- $\beta 1$ é a isoformas predominantemente expressa nos mamíferos (Akhurst et al., 2012). A ação do TGF- $\beta$ se inicia com a ligação de um receptor de membrana que leva a ativação da sinalização intracelular, o qual é propagada pela ativação das proteínas citoplasmáticas da família Smads (Massagué et al 2012). As Smads2/3 fosforiladas formam um heterodímero com a Smad 4 e esse complexo modula a transcrição de genes indutores da FP, como a fibronectina, o colágeno e a FSP-1 (Massagué et al., 2005; Mitu et al., 2008). 
Dentre as Smads identificadas, as Smads 1,5 e 8 atuam como substrato para receptores das BMPs e a Smad 7 apresenta papel inibitório, ou seja, a fosforilação da Smad 2/3 pode ser inibida pela Smad 7, um contrarregulador da via TGF- $\beta /$ Smad (Mitu et al., 2008).

Dados da literatura indicam uma importante participação da via TGF- $\beta /$ Smad na FP. Animais knockout para Smad 3, por exemplo, não desenvolvem FP induzida por soluções de diálise (Duan et al., 2014). É interessante notar também que em ratos transfectados e hiperexpressando o gene da Smad 7 houve proteção da estrutura da MP. Estes resultados indicam que a manipulação da expressão das Smads pode se tornar uma estratégia terapêutica para FP (Guo et al., 2007).

\subsubsection{Modelo Experimental de FP}

O estudo dos mecanismos envolvidos no desenvolvimento da FP são extremamente relevantes, para a identificação de potenciais alvos terapêuticos. A dificuldade de obtenção de amostras de peritôneo de pacientes constitui uma limitação para o estudo desta situação em pacientes. Com o objetivo de superar tais dificuldades, foram desenvolvidos modelos experimentais de FP, embasados principalmente pela constatação que o peritôneo humano é estruturalmente igual ao dos roedores o que facilita mimetizar a situação clínica (Ni et al., 2005).

Um dos modelos experimentais de FP desenvolvidos foi induzido com a utilização de solução de DP, através de cateter peritoneal. A solução de diálise é infundida na cavidade peritoneal e após um determinado tempo de permanência, o dialisato é drenado da cavidade peritoenal. No entanto, esses modelos requerem anestesia, procedimento cirúrgico, geralmente apresentam problemas relacionados ao 
cateter, como infecção e mau funcionamento do cateter, levando à limitação da técnica (Zareie et al., 2005; Wang et al., 2015).

Outro modelo experimental, utilizado não cirúrgico, é o que induz a FP por meio da exposição crônica do peritôneo ao gluconato de clorexidina (GC). Em 1995, Suga e colaboradores foram os primeiros a descrever o desenvolvimento de FP em ratos por meio da administração intermitente de GC (Suga et al., 1995). O modelo é essencialmente baseado na irritação química e peritonite asséptica, a partir da injeção intraperitoneal (IP) intermitente de solução salina contendo $0,1 \%$ de gluconato de clorexidina em $15 \%$ etanol. Em teoria, o GC induz a lesão da MP devido ao rompimento das junções entre as células mesoteliais, com dano subsequente ao tecido subseroso. Esse processo causa uma resposta inflamatória que, quando perpetuada, leva à fibrose tecidual.

Do ponto de vista histológico, animais submetidos a este tipo de processo evoluem com infiltrado inflamatório e progressivo espessamento da zona compacta submesotelial, alterações estas que começam a se manifestar aproximadamente 16 dias após o início da lesão. (Hoff et al., 2005, Suga et al 1995, Yoshio et al., 2004). Essas alterações se assemelham bastante àquelas demonstradas em biópsias de pacientes em DP de longo prazo. Outra vantagem da utilização deste modelo decorre do curto período de tempo necessário para a indução da FP, além da baixa mortalidade.

\subsection{Células-Tronco (CT)}

As CT são células capazes de se autorreplicar, gerando cópias idênticas à célula original e se diferenciar em diversas linhagens celulares (Verfaillie et al., 2002; Rippon et al., 2004; Dominici et al., 2006; Parekkadan \& Milwid et al., 2010). A classificação das CT está baseada em dois critérios. Em primeiro lugar, leva-se em conta a 
plasticidade ou capacidade de diferenciação das células. Neste caso, são classificadas em: totipotentes (podem originar um organismo completo), pluripotentes (podem originar células da ectoderma, endoderma e mesoderma), multipotentes (podem gerar células de um único folheto embrionário) e unipotentes ou progenitoras (podem originar um único tipo celular mantendo sua capacidade de autorreplicação) (Young \& Black et al., 2004; Schena \& Abbattista et al., 2003; Rippon et al., 2004; Fortier et al., 2005).

Em segundo lugar, a classificação é feita de acordo com a origem das células. Neste caso são classificadas em CT embrionárias, adultas ou pluripotentes induzidas. As CT embrionárias são derivadas do embrião em estágio de blastocisto, possuem um grande potencial de diferenciação e autorrenovação. As CT adultas podem ser obtidas de diversos órgãos após o período neonatal, possuem menor potencial de diferenciação e constituem um grupo amplo de células denominadas CT hematopoiéticas e CT mesenquimais. As CT hematopoiéticas são originam todas as linhagens hematológicas e as CT mesenquimais são originadas de vários tecidos e tem capacidade de se diferenciar em diversas linhagens celulares. CT pluripotentes induzidas constituem um grupo de CT provenientes de reprogramação genética de células já diferenciadas, adquirindo, assim, a propriedade de pluripotência (Young et al., 2004, Schena et al., 2003).

\subsubsection{Células Tronco mesenquimais (CTm)}

Nas décadas de 1960 e 1970, Alexander Friedenstein e colaboradores descreveu o primeiro isolamento a partir da medula óssea de rato e observou que as células em cultura com aspecto fusiforme eram capazes de crescerem em colônias (Friedenstein et al., 1970).

Nos anos 90, Caplan e colaboradores propuseram a definição atual de "Células Tronco Mesenquimais" (Mesenchymal Stem Cells - MSC), sendo demonstrado que as 
CTm isoladas de medula óssea foram diferenciadas em linhagem mesodérmica e, posteriormente em linhagens endodérmica e ectodérmica, associando a uma possível capacidade de regeneração tecidual (Caplan et al., 1991; Preston et al., 2003).

Morfologicamente, as CTm são células fibroblastóides, com formato fusiforme e que apresentam unidades formadoras de colônia. Em cultura, as CTm têm a capacidade de se expandir numerosas vezes, mantendo seu potencial de crescimento. O tempo de duplicação depende da origem das células e da densidade de plaqueamento inicial (Castro-Malaspina et al., 1980).

Em 2005 a International Society for Cellular Therapy (ICSCT) determinou critérios mínimos para a caracterização das CTm. De acordo com estes critérios, independentemente da sua fonte de isolamento, as células devem apresentar aderência à superfícies de plástico, devem ainda ter um potencial para diferenciação osteogênica, condrogênica e adipogênica e, por fim, devem expressar moléculas de superfície celular positivas para CD105, CD73 e CD90 e negativas para CD45, CD34, CD14, CD11b, CD19 e HLA-DR (Dominici et al., 2006).

As CTm são fáceis de isolar e cultivar in vitro. Outro aspecto importante é que as CTm são consideradas células imunoprivilegiadas, ou seja, dificilmente são rejeitadas. Estas células modulam o sistema imune, bloqueando a ação dos linfócitos T CD4+, CD8+, células NK e linfócitos B (Shi et al., 2011). Devido à baixa expressão de MHC classe I e ausência da expressão de MHC classe II e de moléculas coestimulatórias, as células não induzem a ativação de uma resposta imune (Feng et al., 2013).

As CTm possuem um maior potencial para o desenvolvimento de pesquisas quando comparado a CT embrionárias, pois são aceitas do ponto de vista ético e religioso e não possuem risco de formar teratoma. Por esses motivos, as CTm 
apresentam um grande potencial para o tratamento de várias doenças (Guan et al., 1999; Odorico et al., 2001; Navarro-Alvarez et al., 2008; Bassi et al., 2012, Ma et al., 2014).

A eficácia e a segurança na administração das CT dependem de alguns critérios, os quais estão a fonte de obtenção das células, a idade do doador, o tipo de célula que será aplicada, as doses e volumes mínimo e máximo (milhares ou milhões) administrados, as vias de inoculação, estágio da doença do receptor comparado ao momento da administração das células (Caplan et al., 1991; Zachar et al., 2016).

\subsubsection{Células Tronco mesenquimais de Tecido Adiposo (CTmTA)}

As CTm podem ser isoladas a partir de diversas fontes, como o tecido adiposo, o fluido sinovial, o periósteo, o sangue do cordão umbilical, a placenta e o líquido amniótico (Murphy et al., 2013).

O tecido adiposo é de origem mesodérmica e contém uma população celular estromal heterogênea. Em adultos, o tecido adiposo predominante é o tecido adiposo branco, o qual se distribui como tecido adiposo branco subcutâneo e tecido adiposo branco visceral, contendo adipócitos maduros, pré-adipócitos, fibroblastos, células vasculares do músculo liso, células endoteliais, monócitos, macrófagos residentes e linfócitos (Zuttion et al., 2013).

Quando comparado com CTm provenientes de outras fontes o tecido adiposo possui vantagens, como o baixo risco para os doadores e obtenção de grande quantidade de tecido (100mL até 1litro de tecido adiposo) por meio da lipoaspiração. Com o aumento da incidência de obesidade, o tecido adiposo subcutâneo torna-se abundante e acessível, além disso, o tecido lipoaspirado é rotineiramente descartado (Bunnell et al., 2008; Hakan et al., 2012). 
Pesquisas demonstraram que pequenas quantidades de tecido adiposo proporcionam um grande rendimento de CT: um grama de tecido adiposo, por exemplo, é capaz de produzir aproximadamente $5 \times 10^{3} \mathrm{CTm}$. Este rendimento é muito maior que o obtido das CTm extraídas a partir da medula óssea (CTmMO), aproximadamente 100 a $1 \times 10^{3}$ células $/ \mathrm{mL}$. Além disso, as facilidades da extração das CTm a partir do tecido adiposo contrastam quando comparadas ao procedimento invasivo de aspiração da medula óssea (Bunnell et al., 2008; Hakan et al., 2012).

Quanto ao seu potencial de diferenciação, as CTmTA apresentam um potencial adipogênico superior e as CTmMO um potencial osteogênico superior, com uma produção de colágeno mais efetiva nas CTmTA. As CTmTA tendem a ser geneticamente e morfologicamente mais estáveis em culturas de longo prazo, com baixa senescência e maior capacidade de proliferação. Portanto, o tecido adiposo é considerado de fácil cultivo, com taxa de sucesso de isolamento de $100 \%$, é um método mais barato, menos invasivo e doloroso quando comparado às CTmMO (Yarak et al., 2010; Zuttion et al., 2013; Laura et al., 2016;).

A capacidade das CTmTA de secretar grandes quantidades de fatores de crescimento específicos, citocinas ou outros fatores parácrinos em seu ambiente alvo pode ser utilizada para aplicações regenerativas terapêuticas.

\subsection{Vesículas Extracelulares (VE)}

Uma característica essencial nos organismos é a comunicação intercelular, e esta pode ser mediada por contato direto célula-célula ou pela transferência de moléculas secretadas. As VE podem ser liberadas pela maioria das células e são classificadas com base na sua origem celular ou biogênese (Raposo et al., 1996). 
As VE foram primeiramente descritas por Pan e Johnstone em 1983, com estudos detalhados de ultraestrutura das VE. Inicialmente, a liberação das VE foi descrita como um mecanismo pelo qual as células eliminavam proteínas indesejadas e outras moléculas, as quais durante muito tempo foram consideradas fragmentos ou restos celulares sem função específica. Entre 2006-2007, foi demonstrado que as VE contêm RNA, incluindo o microRNA, e são mediadoras da comunicação célula a célula ampliando o campo de interesse. Avançando nesses estudos pioneiros, VE foram isoladas da maioria dos tipos de células e fluidos biológicos. Depois de anos de investigação, as VE vêm ganhando cada vez mais importância na biologia celular, devido a sua capacidade de mediar a comunicação célula-a-célula e ao seu potencial como uso terapêutico (Rani et al., 2015; Yáñez-mó et al., 2015).

Estudos relatam que o conteúdo, tamanho e composição da membrana das VE são altamente heterogêneos, dinâmicos e dependem da fonte celular e do estado e condições ambientais. Atualmente, pelo menos três subgrupos principais de VE foram definidos: exossomos, microvesículas e corpos apoptóticos. Todos os quais são envoltos por uma camada bilipídica e contêm proteínas, RNAm e microRNA. No entanto, no caso específico dos corpos apoptóticos há também DNA fragmentado (György et al., 2011; Yáñez-mó et al., 2015).

As principais características e os tipos de VE são apresentados na tabela 1. As microvesículas apresentam diâmetro de 100-1.000nm e são secretadas para o espaço extracelular por brotamento a partir da membrana celular. Os exossomos possuem

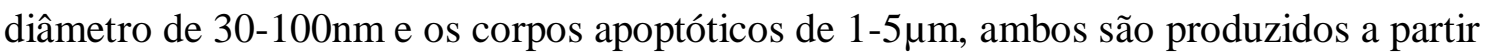
da invaginação da membrana plasmática (Mathivanan et al., 2010). 
Tabela 1. Classificação das VE (modificado de Andaloussi et al.,2013)

\begin{tabular}{|l|l|l|l|}
\hline \multicolumn{2}{|c|}{ Exossomo } & \multicolumn{1}{c|}{ Microvesículas } & \multicolumn{1}{c|}{ Corpos apoptóticos } \\
\hline Origem & $\begin{array}{l}\text { Invaginação da membrana } \\
\text { plasmática }\end{array}$ & $\begin{array}{l}\text { Superfície celular, por } \\
\text { brotamento da membrana } \\
\text { celular }\end{array}$ & $\begin{array}{l}\text { Invaginação da } \\
\text { membrana plasmática }\end{array}$ \\
\hline Tamanho & $40-100 \mathrm{~nm}$ & $1000-1000 \mathrm{~nm}$ & $\mathrm{~nm}$ \\
\hline Marcadores & $\begin{array}{l}\text { CD3, CD9, Alix, TSG 101, } \\
\text { HSP70 }\end{array}$ & $\begin{array}{l}\text { anexina V, Fiotilina-2, CD40 } \\
\text { selectina, integrina, } \\
\text { metaloproteinases }\end{array}$ & $\begin{array}{l}\text { anexina V, DNA, } \\
\text { histonas }\end{array}$ \\
\hline & $\begin{array}{l}\text { proteínas citoplasmáticas de } \\
\text { transporte, apresentadoras de } \\
\text { antígeno e adesivas } \\
\text { (tetraspaninos, integrinas); } \\
\text { lipídios, ácidos nucléicos } \\
\text { (RNAm, microRNA) }\end{array}$ & $\begin{array}{l}\text { proteínas citoplasmáticas de } \\
\text { transporte, apresentadoras de } \\
\text { antígeno e adesivas } \\
\text { (tetraspaninos, integrinas); } \\
\text { lipídios, ácidos nucléicos } \\
\text { (RNAm, microRNA) }\end{array}$ & $\begin{array}{l}\text { proteínas citoplasmáticas } \\
\text { de transporte, } \\
\text { apresentadoras de antígeno } \\
\text { e adesivas (tetraspaninos, } \\
\text { integrinas); lipídios, ácidos } \\
\text { nucléicos (RNAm, } \\
\text { microRNA) e DNA } \\
\text { fragmentado }\end{array}$ \\
\hline
\end{tabular}

As VE podem ser isoladas a partir de vários tipos celulares e a partir do sobrenadante de cultura de diversos tipos de linfócitos, incluindo células T e B, células dendríticas, plaquetas, mastócitos, células epiteliais, células endoteliais, células neurais, células cancerosas e das CTm (Rani et al., 2015).

Apesar dos avanços recentes, estudos publicados alternam os termos exosoma e microveículas, devido às inconsistências nos protocolos de purificação e à falta de caracterização completa das VE. Para determinar o tipo de VE é necessário a utilização de protocolos de purificação seguindo características que estão apresentadas na tabela 2 (Andaloussi et al., 2013).

Um aspecto importante é que os exossomas e as microvesículas estão envolvidos na comunicação celular, possivelmente através da transferência horizontal de material genético e proteínas, estimulando diretamente a célula alvo (György et al., 2011; Yáñez-Mó et al., 2015). 


\subsubsection{Classificacão das VE}

As principais diferenças entre os exossomos e as microveículas são o tamanho, formação, e o processo de secreção.

As microveículas são formadas por brotamento regulado a partir da membrana plasmática. A composição da membrana das microvesículas é um reflexo da célula mãe (Andaloussi et al 2013). Alguns estudos indicam que as microvesículas tendem a ter um repertório de proteínas (integrinas, glicoproteínas, p-selectinas) diferente dos exossomos. Além disso, as microvesículas carregam mais glicoproteínas e fosfoproteínas quando comparadas aos exossomos (Heijnen et al., 1999).

Os exossomas são formados a partir de corpos multivesiculares, organelas intracelulares originadas dos endossomas. A membrana plasmática sofre invaginação e forma os endossomas primários, que podem interagir com o aparelho de Golgi e com o retículo endoplasmático, dando origem aos endossomas secundários chamados CMVs. Os CMVs estão envolvidos em inúmeras funções endocíticas e de tráfico, incluindo reciclagem, transporte, armazenamento e liberação de proteínas (Borges et al., 2013). Alguns estudos indicam que os exossomos são enriquecidos em proteínas transmembranares e glicoproteínas.

Muitas proteínas como tetraspaninas, proteínas ESCRT, Alix, TGS101 e chaperonas de choque térmico são comumente encontradas em todos os tipos de VE, independente da célula de origem e podem ser utilizados como marcadores gerais (Théry et al., 2011, Zaborowski et al., 2015). 


\subsubsection{Métodos de isolamento e caracterizacão de VE}

Uma grande variedade de métodos é empregada com o objetivo de isolar as VE. No entanto, o método mais amplamente descrito é o da ultracentrifugação (Théry et al., 2006). A ultracentrifugação é um procedimento rotineiramente utilizado para a separação de organelas celulares, baseado na diferença de sedimentação de partículas de acordo com o seu tamanho. As VE precipitam a partir de 20.000 x g, chegando até $100.000 \mathrm{xg}$, para o seu isolamento.

A posterior caracterização das VE isoladas requer o uso de técnicas de detecção e quantificação, sendo elas: microscopia eletrônica de transmissão, citometria de fluxo, rastreamento de nanopartículas, análise de proteínas totais, Western blot e ExoElisa. Considerando-se que existem variações nos métodos de obtenção, identificação e caracterização das VE, em 2014 a Sociedade Internacional de Vesículas Extracelulares (Internacional Society for Extracellular Vesicles - ISEV) definiu critérios mínimos para a caracterização destas estruturas. Atualmente, tais critérios incluem a análise semiquantitativa da composição proteica das VE, comumente por Western Blot, para os marcadores CD9, CD63, CD81, Alix ou TGS101; análise do tamanho das VE por NTA, por Ligh Scattering dinâmico (DLS) ou Resistive Pulse Sensing (TRPS) e análise da morfologia por microscopia eletrônica de transmissão (Lötvall et al., 2014).

A morfologia das VE isoladas é analisada, na maioria dos casos, por microscopia eletrônica, que também é um método utilizado para confirmar o tamanho das VE. A citometria de fluxo é uma técnica conveniente na caracterização das VE apenas no tocante às dimensões médias das partículas da população isolada. Mesmo assim, deve-se considerar que as microvesículas, e principalmente os exossomos, estão no limiar inferior de detecção $(500 \mathrm{~nm})$, o que torna muitas vezes difícil separá-las do ruído de fundo do aparelho. Mais recentemente, o tamanho das VE tem sido 
determinado pela análise de rastreamento de nanopartículas (NTA), que usa o espalhamento de luz de partículas em suspensão para calcular o tamanho e a distribuição populacional de amostras na faixa de 10 a 2000 nm (Franquesa et al., 2014).

Para a quantificação das VE isoladas, o método mais utilizado é a determinação da concentração proteica do material ao final do processo de ultracentrifugação. Entretanto, o que se obtém é uma estimativa indireta do volume de VE, já que o que se mede são as proteínas presentes no material, que acredita-se serem as da superfície das VE.

A caracterização do pool de proteínas e peptídeos carreados pelas VE é feita basicamente por Western blot. Esta técnica, porém, não é adequada para a determinação da quantidade de VE presentes nas amostras. Entre os métodos utilizados para a quantificação das proteínas está a quantificação das proteínas totais pelo kit de ensaio de proteína ExoElisa (Franquesa et al., 2013). A quantificação das VE pode ser feita por ELISA para medir a concentração de proteína específica das VE. Essa técnica é baseada nas reações antígeno-anticorpo detectáveis através de reações enzimáticas. Na literatura, alguns trabalhos consideram que as microvesículas têm mais integrinas e os exossomos mais tetraspaninas (Heijnen et al., 1999; Borges et al., 2013). A variabilidade nas formas de isolamento e na expressão de proteínas específicas para microvesículas e exossomos causa confusão para determinar marcadores específicos, portanto, esses marcadores são comumente encontrados como marcadores gerais.

\subsubsection{Funcões das VE}

A principal função das VE é pleiotrópica, exercendo efeitos fundamentais nos processos biológicos. Sua ação ocorre diretamente sobre receptores de superfície 
celular, proteínas e ligantes de lipídios bioativos, qua após se fundirem à membrana plasmática da célula receptora, entregam o seu conteúdo para as células receptoras (Andaloussi et al., 2013).

A célula receptora pode interagir com as VE através de mecanismos diferentes. Proteínas de membrana podem se ligar a receptores específicos na membrana plasmática celular ou na matriz extracelular, tais como receptor de transferrina, receptores do fator de necrose tumoral (TNF), integrinas e tetraspaninas (como CD9 ou CD81), ancorando-se na célula alvo para entrega do conteúdo celular. Outro mecanismo é o de absorção, que envolve a fusão com a membrana da célula receptora, resultando na transferência do conteúdo intravesicular (RNAms, microRNAs, proteínas e moléculas de sinalização ou endocitose) (Borges et al., 2013).

As VE podem mediar a comunicação intracelular por mecanismos parácrinos e, provavelmente também por mecanismo endócrino, agindo através da circulação sistêmica, semelhante aos hormônios (Andaloussi et al., 2013).

Outra importante função na comunicação celular é que as VE possuem a capacidade de transportar e proteger seu conteúdo de enzimas degradativas como RNases, tripsinas e outras substâncias químicas. Isso ocorre desde que se mantenha íntegra a membrana bilipídica (Yáñez-mó et al., 2015).

\subsection{Terapia Celular}

\subsubsection{Potencial terapêutico das CTm}

As CTm estão envolvidas em muitos processos fisiológicos e patológicos, incluindo a manutenção da homeostase tecidual, senescência, danos nos tecidos e doenças inflamatórias. O efeito terapêutico mais proeminente das CTm é exercido pela 
capacidade de reparar o tecido, modulando o ambiente em que residem e influenciando a resposta imune (Ma et al., 2014; Ramaswamy et al., 2016).

As CTm possuem essa capacidade reparadora por apresentarem propriedades tróficas que ocorrem através da secreção de fatores de crescimento (Murphy et al., 2013).

A lesão tecidual está sempre associada à ativação de células imunes/inflamatórias, não só macrófagos e neutrófilos, mas também células imunes adaptativas, incluindo linfócitos T CD4+, linfócitos T CD8+ e linfócitos B. Em resposta a essas células e aos mediadores inflamatórios tais como IL-1, IL-12, TNF- $\alpha$ e INF- $\gamma$, as CTm secretam uma gama de proteínas anti-inflamatórias, particularmente as citocinas imunomoduladoras que incluem TGF- $\beta$, HGF, FGF, PDGF, IGF-1, SDF-1 e angiopoietina, muitos desses regulados pela ativação do fator de transcrição NF-kB. Além disso, também liberam as VE - que contém proteínas reparadoras, RNAm e microRNAs, que agem modulando o microambiente por mecanismos anti-inflamatórios e, dessa forma, impedem a proliferação e a função efetora de muitas células imunes inflamatórias, incluindo linfócitos $\mathrm{T}$, células NK (Natural killer), linfócitos $\mathrm{B}$, monócitos, macrófagos e células dendríticas. (Caplan et al 1991; Gao et al., 2016). Essa forma de ação, é possivelmente, o mecanismo que as CTm agem para participar do processo de regeneração e reparo tecidual (Spees et al., 2016).

\subsubsection{CTm na Fibrose Peritoneal}

Inicialmente, as CTm foram descritas como mediadoras da reparação tecidual. Acreditava-se que elas agiam por substituição das células danificadas em virtude do seu potencial de diferenciação em múltiplas linhagens (Mahmood et al., 2003, Murphy et al., 2003). No entanto, resultados posteriores sugerem que este mecanismo é pouco 
provável. Em resposta à lesão de tecido, as CTm contribuem de maneira parácrina. As CTm possuem também ação anti-apoptótica, anti-inflamatória e pró-angiogênica (Caplan et al., 1991; Prockop et al., 2009; Muñoz-Espín et al., 2014).

Estudos em modelos experimentais de FP sugerem que CTm são benéficas reduzindo a inflamação e a fibrose. Ueno e colaboradores (Ueno et al., 2013) utilizaram um modelo de FP induzido por injeções intraperitoneais de 0,1\% de GC, administrado por 21 dias. $\mathrm{O}$ tratamento foi realizado por via intraperitoneal com administração de $1 \times 10^{7}$ de CTmMO no $21^{\circ}$ dia. Foi relatada redução significativa do espessamento peritoneal e da deposição de colágeno. Resultados semelhantes foram obtidos em um modelo de lesão peritoneal induzido por raspagem peritoneal (Wang et al., 2012).

Devido às propriedades imunomoduladoras e tróficas das CTm, essas se tornaram candidatas atraentes para o tratamento da fibrose. Estudos pré-clínicos sugerem um efeito promissor em uma variedade de modelos. Analisando estes modelos, Usunier e colaboradores em um estudo de revisão sugerem que os mecanismos de ação das CTm ocorrem por modulação imunológica, inibição da diferenciação mediada por TGF- $\beta$ pela transição epitelial mesenquimal, inibição do estresse oxidativo e remodelação da matriz (Usunier et al., 2014; Spees et al., 2016).

\subsubsection{Terapia com VE}

Estudos relatam que a administração de microvesículas derivadas de CTm tem capacidade de recuperar a lesão renal em diversos modelos animais (induzido por glicerol, cisplatina e isquemia/reperfusão) (Bruno et al., 2009; Gatti et al., 2011; Bruno et al., 2012). Reis e colaboradores relataram que os exossomos extraídos de CTm possuem efeitos renoprotetores em modelo de lesão renal aguda induzida por gentamicina (Reis et al., 2012). 
Em modelo de infarto agudo do miocárdio, foi observada redução da inflamação, redução da fibrose e melhora na função cardíaca (Murphy et al., 2003; Zuttion et al., 2013; Muñoz-Espín et al., 2014; Börger et al., 2017). Na injúria hepática por isquemia/ reperfusão houve diminuição da injúria no fígado, redução da apoptose e induziu a proliferação de hepatócitos (Wakabayashi et al., 2014; Börger et al., 2017).

O local de administração, o número de injeções e a dose de VE usadas nos trabalhos publicados são muito variáveis. Entretanto, na maioria dos modelos, os efeitos positivos das VE são relatados a partir de uma concentração proteica de $50 \mu \mathrm{g}$, chegando a $400 \mu \mathrm{g}$ de VE por aplicação (Börger et al., 2017).

Atualmente, há pelo menos dois estudos clínicos publicados utilizando VE. O primeiro estudo foi realizado para o tratamento da doença do enxerto contra o hospedeiro. Neste estudo, foram feitas 4 aplicações de VE obtidas do meio condicionado de $4 \times 10^{7} \mathrm{CTmMO}$. As aplicações foram realizadas durante um período de 3 dias e de forma crescente. Após cada aplicação, houve melhora dos sintomas clínicos da doença do enxerto contra o hospedeiro e foi relatado diminuição na dosagem dos medicamentos. Embora o paciente tenha morrido devido a pneumonia 7 meses após a aplicação das VE, houve melhora relatada até um período de 4 meses após tratamento (Kordelas et al., 2014).

O outro trabalho foi realizado por um grupo do Egito que propôs a administração de duas doses de VE derivadas de CT do cordão umbilical para DRC nos estágios 3 e 4. Neste estudo, foram selecionados 40 pacientes divididos em dois grupos, metade dos pacientes foram tratados com placebo (soro fisiológico) e a outra metade com duas doses de $100 \mu \mathrm{g} / \mathrm{kg} /$ dose de VE derivadas de CT do cordão umbilical congeladas. A primeira dose de VE foi endovenosa e a segunda dose, após uma semana, na artéria renal. Os pacientes foram acompanhados durante um período de 1 ano. As análises 
foram feitas em vários períodos (antes do início do tratamento, com 4 semanas, 8 semanas, 12 semanas, 6 meses, 9 meses e 12 meses). Após 4 semanas de tratamento, os pacientes apresentaram melhora significativa na função renal com aumento da taxa de filtração glomerular, diminuição no nível de ureia e creatinina sérica. Além disso, apresentaram aumento significativo nos níveis plasmáticos de TGF- $\beta$ e IL-10 e diminuição significativa dos níveis plasmáticos de TNF- $\alpha$, quando comparado ao grupo tratado com placebo. Não foi observado nenhum efeito colateral causado pelas VE (Nassar et al., 2016).

Os dados apresentados demonstram que as VE derivadas de CTm representam uma possível opção de terapia celular. 


\section{RACIONAL}

Ao longo dos anos, a DP promove modificações na MP caracterizadas por graus variáveis de inflamação e principalmente $\mathrm{FP}$, que podem refletir na eficácia desse método dialítico e na sobrevida do paciente. Um dos maiores desafios é interromper esse processo de progressão da FP. Atualmente, não existe tratamento para esta complicação da DP. Desse modo, estratégias terapêuticas que previnam a progressão dessa complicação são de suma importância. Neste contexto, as CTm apresentam potencial efeito benéfico reduzindo a inflamação e a fibrose, através de mecanismos predominantemente parácrinos.

Dado que as CTm apresentam efeitos benéficos através de mecanismos parácrinos, ou seja, por mediadores secretados pelas CTm, foi formulada a hipótese de que a administração de VE, ao entregar seu conteúdo (mRNAs, miRNAs, proteínas) para as células alvo, poderia ter efeitos semelhantes à administração de CTm. Assim, o presente estudo teve como objetivo comparar o possível efeito terapêutico da administração de CTmTA ou de VE derivadas de CTmTA na prevenção da FP experimental, em ratos. Para tanto, foi utilizado um modelo experimental de FP que induz a FP por meio da exposição do peritôneo ao GC. 


\section{OBJETIVOS}

O objetivo central do presente estudo foi comparar o possível efeito terapêutico da administração da CTmTA ou de VE derivadas de CTmTA na prevenção da fibrose peritoneal experimental em ratos.

Os seguintes objetivos secundários foram delineados:

1. Estabelecimento do protocolo de isolamento e quantificação de VE derivadas de CTmTA;

2. Análise comparativa da administração de CTmTA ou de VE no modelo experimental de FP induzido por CG;

3. Avaliação histológica do peritôneo, para análise do grau de espessamento da MP, através da coloração com Tricrômio de Masson;

4. Análise de miofibroblastos ( $\alpha$-SMA) no peritôneo, por imunohistoquímica;

5. Análise da expressão de fibronectina e fatores envolvidos na fibrogênese (TGF- $\beta$ e FSP-1) no peritôneo, por PCR em tempo real;

6. Análise da via TGF- $\beta /$ Smad através da expressão do Smad3 e Smad7 no peritôneo, por PCR em tempo real;

7. Análise do peritôneo para identificar e quantificar macrófagos (ED1) e linfócitos T (CD43), por imunohistoquímica.

8. Análise da expressão da citocina pró-inflamatória TNF- $\alpha$ no peritôneo por PCR em tempo real;

9. Análise da função peritoneal medida pelo transporte de glicose e ultrafiltração peritoneal;

10. Análise da densidade capilar e da expressão do VEGF no peritôneo, por imunofluorescência e por PCR em tempo real; 


\section{MATERIAIS E MÉTODOS}

\subsection{Animais}

Foram utilizados ratos Wistar machos, com peso entre $280 \mathrm{~g}$ e $320 \mathrm{~g}$, que foram obtidos no Biotério Central da Faculdade de Medicina da Universidade de São Paulo (FMUSP). Os animais foram mantidos em gaiolas para roedores, a uma temperatura de $22^{\circ} \mathrm{C}$, com fotoperíodos de luz e escuridão de $12 / 12 \mathrm{~h}$ e com livre acesso a água e ração padrão. A metodologia aplicada durante o protocolo experimental foi aprovada pela Comissão de Ética em Pesquisa da FMUSP (protocolo nº 165/15).

\subsection{Modelo Experimental de FP}

Para a indução da FP foi utilizado um modelo clássico com GC a $0,1 \%$ em etanol a 15\% (1 ml/100 g) dissolvido em solução salina. Os ratos receberam injeções de GC na dose de $1 \mathrm{~mL} / 100 \mathrm{~g}$ de peso em dias alternados durante 30 dias. Os animais receberam o analgésico Cloridrato de Tramadol na dose de $5 \mathrm{mg} / \mathrm{Kg}$, por via subcutânea, antes das injeções IP de GC e posteriormente a cada 8 horas durante todo protocolo de 30 dias.

\subsection{Isolamento e caracterização de CTmTA}

\subsubsection{Isolamento e cultivo de CTmTA}

4.3.1.a) Isolamento: As CTmTA foram isoladas de ratos Wistar adultos. Após a eutanásia, o tecido adiposo subcutâneo gonadal foi removido, picado e digerido com colagenase a $0,075 \%$ (Sigma-Aldrich, St. Louis, EUA) por 40 minutos e $37^{\circ} \mathrm{C}$, em 
agitação constante. Após a completa digestão, foi adicionado soro fetal bovino (SFB), e o homogenato foi centrifugado por 5 minutos a $1600 \mathrm{rpm}$. O sobrenadante foi removido e o pellet foi ressuspendido em 10,0 mL de de meio de cultura completo (DMEM-Low Glucose contendo SFB a $10 \%$ e antibióticos) e plaqueado em um fraco para cultura de $75 \mathrm{~cm}^{3}$ e mantido em estufa úmida a $37^{\circ} \mathrm{C}$.

4.3.1.b) Tripsinização: Com as células na confluência de $80 \%$, e com crescimento em colônia e formato fibroblastóide, o meio de cultura foi retirado e as células lavadas com PBS estéril por 3 vezes. Em seguida à lavagem, foram adicionados 3,0 $\mathrm{mL}$ de solução de tripsina $0,25 \%$ (Gibco-Invitrogen, Rockville, EUA) a $37^{\circ} \mathrm{C}$ por 1 minuto. $\mathrm{O}$ frasco para cultura com as CTmTA foi agitado levemente para o desprendimento total das células e em seguida, para inibir a ação da tripsina, foi utilizado meio de cultura suplementado com SFB 10\%. As células foram transferidas para tubos cônicos de 15,0 mL (Becton Dickinson, San Jose, EUA) e centrifugados à 1600 rpm por 5 minutos, (centrífuga Eppendorf 5810R, Hamburgo, Alemanha). O sobrenadante foi desprezado e o pellet foi ressuspenso com 1,0 $\mathrm{mL}$ de meio de cultura completo. Em seguida foi realizada a contagem de células viáveis, utilizando a coloração de azul de trypan, e a partir dessa contagem as CTmTA foram novamente plaqueadas. A tripsinização e o replaqueamento das células são determinados como passagem celular.

4.3.1.c) Cultivo e expansão: Após a contagem, as células foram cultivadas em frascos de cultura de $75 \mathrm{~cm}^{2}$ (Corning Life Science, Lowell, EUA), contendo meio de cultura completo e incubadas em estufa úmida a $37^{\circ} \mathrm{C}$ a $5 \%$ de $\mathrm{CO}^{2}$ (Thermo Fisher Scientific, Marietta, EUA). O cultivo celular foi monitorado por microscopia invertida, e o meio de cultura foi trocado três vezes por semana. As células foram tripsinizadas e replaqueadas 
sempre que atingiram uma confluência de $80 \%$. As células utilizadas neste estudo foram mantidas em cultura até a $4^{\mathrm{a}}$ passagem celular.

\subsubsection{Caracterizacão de CTmTA}

4.3.2.a) Citometria de fluxo: A caracterização das populações celulares presentes nas amostras de Tecido Adiposo foi determinada pelo método de citometria de fluxo. A presença dos marcadores celulares foi analisada por diferentes anticorpos monoclonais (Tabela 1) conjugados com diferentes fluorocromos: isotiocianato de fluoresceína (FITC, do inglês fluorescein isothiocyanate), e ficoeritina (PE, do inglês phycoeritin). Controles de marcações inespecíficas foram utilizados para a adequada calibração do aparelho, análise dos resultados e definição da positividade da amostra. Todos os anticorpos foram adquiridos da empresa eBioscience, San Diego, EUA.

Tabela 2. Anticorpos utilizados para caracterização das CTmTA por citometria de fluxo.

\begin{tabular}{|c|c|c|c|c|}
\hline Anticorpo & Especificidade & $\begin{array}{c}\text { Fluorocromo } \\
\text { Conjugado }\end{array}$ & Isotipo & Concentração \\
\hline Anti-CD29 & CTm & FITC & $\begin{array}{c}\text { Armenian } \\
\text { Hamster } \\
\text { lgG }\end{array}$ & $0,5 \mathrm{mg} / \mathrm{mL}$ \\
\hline Anti-CD44 & CTm & PE & $\begin{array}{l}\text { Mouse } \\
\text { IgG2a, } \\
\text { Kappa }\end{array}$ & $0,2 \mathrm{mg} / \mathrm{mL}$ \\
\hline Anti-CD45 & $\begin{array}{c}\text { Pan- } \\
\text { leucocitário }\end{array}$ & APC & $\begin{array}{l}\text { Mouse } \\
\text { lgG1, } \\
\text { Kappa }\end{array}$ & $0,2 \mathrm{mg} / \mathrm{mL}$ \\
\hline Anti-CD90-1 & CTm & FITC & $\begin{array}{l}\text { Mouse } \\
\text { IgG2a, } \\
\text { Kappa }\end{array}$ & $0,5 \mathrm{mg} / \mathrm{mL}$ \\
\hline Anti-CD-105 & CTm & PE & $\begin{array}{l}\text { IgG2a, } \\
\text { Kappa }\end{array}$ & $0,2 \mathrm{mg} / \mathrm{mL}$ \\
\hline
\end{tabular}

As CTmTA obtidas e quantificadas como descrito anteriormente foram ajustadas à concentração de $2,5 \times 10^{5} \mathrm{em} 100,0 \mu \mathrm{L}$. Em seguida, $100,0 \mu \mathrm{L}$ foram transferidos para um tubo específico para citometria (Becton Dickinson, San Jose, EUA) e incubados 
com os anticorpos conjugados aos fluorocromos por um período de 30 minutos, em campo escuro, à $4^{\circ} \mathrm{C}$. Em seguida, foi acrescentado $1,0 \mathrm{~mL}$ de PBS gelado e a solução foi vortexada. Posteriormente, os tubos foram centrifugados a $2000 \mathrm{rpm}$ por 6 minutos a temperatura ambiente (Eppendorf 5810R, Hamburgo, Alemanha). O sobrenadante foi descartado e o precipitado celular foi homogeneizado e ressuspenso em 500,0 $\mu \mathrm{L}$ de solução de formaldeído diluído a $1 \%$ em PBS (Formaldeído PA, Vetec, Brasil) e estocado em geladeira ao abrigo da luz por um período máximo de 24 horas, até o momento da leitura no citômetro de fluxo. As células foram adquiridas e a intensidade de fluorescência foi captada pelo citômetro de fluxo no aparelho FacsCanto (Becton Dickinson, San Jose, EUA). Os dados foram analisados no CellQuestTM (Becton Dickinson, San Jose, EUA). Para cada amostra foi realizada uma aquisição de 20.000 eventos. Os resultados foram fornecidos e analisados na forma de histogramas e em percentual da população celular com reação positiva para cada anticorpo.

\subsection{2.b) Diferenciação celular}

Osteogênica: A técnica para diferenciação adipogênica de cultura de CTm de rato foi padronizada a partir de diferentes protocolos testados em nosso laboratório. As células aderentes foram cultivadas em placas de 6 poços na densidade celular de $5 \times 10^{3}$ céls $/ \mathrm{mL}$, com meio DMEM-Low glicose mais SFB a 10\%, acrescido de GlutaMax-I (0,2 M) e Gentamicina $(10,0 \mathrm{mg} / \mathrm{mL})$ por 4 dias. A seguir foi realizada a substituição do meio de cultura por um meio condicionado, próprio para diferenciação osteogênica STEMPRO® Osteocyte Differentiation Basal Medium, STEMPRO® Osteogenesis Supplement e Gentamicina $(10,0 \mathrm{mg} / \mathrm{mL})$. A troca de meio de diferenciação foi realizada a cada 3 dias pelo período de 21 dias. A placa foi mantida em estufa úmida a $37^{\circ} \mathrm{C}$ a $5 \%$ de $\mathrm{CO}_{2}$. Depois de completar o período de incubação, as células foram lavadas com PBS por 5 
minutos e, em seguida, fixadas em paraformaldeído a 4\% durante 30 minutos, lavadas com água destilada, e coradas com vermelho de alizarina $(2,0 \mathrm{~g}$ em 100,0 mL de água destilada) em pH 4,2 (Sigma-Aldrich, Saint Louis, EUA), durante 5 a 10 minutos e cuidadosamente lavadas com PBS.

Adipogênica: A técnica para diferenciação adipogênica de cultura de CTm de rato foi padronizada a partir de diferentes protocolos testados em nosso laboratório. As células foram extraídas do Tecido adiposo como descrito anteriormente, colocadas em placas de 6 poços na concentração de $5 \times 10^{3}$ células por poço e mantidas em meio de crescimento DMEM-low glicose mais SFB a 10\%, acrescido de GlutaMax-I (200mM) e Gentamicina $(10 \mathrm{mg} / \mathrm{mL})$, por 4 dias até atingirem a confluência de $80 \%$. A partir daí adicionou-se o meio de diferenciação STEMPRO® Adipocyte Differentiation Basal Medium e STEMPRO® Adipogenesis Supplement a uma concentração final de 1x, além de 5,0 $\mu \mathrm{g} / \mathrm{mL}$ de Gentamicina. As trocas do meio foram realizadas a cada três dias, pelo período de 14 dias. Depois de completado o período de incubação, as células foram fixadas com formalina $4 \%$ por 30 minutos e lavadas com PBS. Posteriormente as células foram incubadas por 10 minutos com Oil Red 0,5\% (Sigma-Aldrich, Saint Louis, EUA) para coloração. Após lavagem com PBS foram observados ao microscópio a presença de vacúolos lipídicos corados em vermelho.

Condrogênica: A diferenciação condrogênica das CTmTA ocorreu de forma semelhante a adipogênica. Uma concentração de $5 \times 10^{3}$ de células colocadas em placas de 6 poços e mantidas em meio de crescimento DMEM-low glicose mais SFB a 10\%, acrescido de GlutaMax-I $(2 \mathrm{mM})$ e Gentamicina $(10 \mathrm{mg} / \mathrm{mL})$, por 4 dias. Ao atingirem a confluência de $80 \%$, o meio de cultura foi substituído por um meio de diferenciação STEMPRO® Condrocyte Differentiation Basal Medium (1X), STEMPRO® Chondrogenesis 
Supplement $(1 \mathrm{X})$ e gentamicina $(10 \mathrm{mg} / \mathrm{mL})$. As trocas do meio foram feitas a cada 3 dias, pelo período de 14 dias. Após o período de incubação, as células foram fixadas com formalina $4 \%$ por 30 minutos e lavadas com PBS. Posteriormente as células foram incubadas por 10 minutos com Alcian Blue (Sigma-Aldrich, Saint Louis, EUA) para coloração. Após lavagem com PBS foram observados, ao microscópio, a presença de vacúolos lipídicos corados em vermelho.

\subsection{Isolamento e caracterização de VE}

\subsubsection{Isolamento de VE}

4.4.1.a) Cultivo e expansão das CTmTA: As CTmTA foram isoladas e cultivadas até a $4^{\mathrm{a}}$ passagem. Ao atingirem $80 \%$ de confluência $\left(\sim 2 \times 10^{6}\right.$ células $)$, o meio de cultura completo foi substituído por meio de cultura puro (DMEM-Low Glucose) contendo antibióticos, mas sem SFB, para minimizar possíveis contaminações de proteínas contidas no soro.

4.4.1.b) Avaliação da viabilidade celular das CTmTA: Após 24 horas de cultivo na ausência do soro fetal bovino, as células foram tripsinizadas e a viabilidade celular foi determinada pela coloração de Tripan Blue, como descrito anteriormente. Para análise por Iodeto de Propídio, $2,5 \times 10^{5}$ de células foram ressuspensas, às quais adicionadas 5,0 $\mu \mathrm{L}$ na concentração de $0,05 \mu \mathrm{g} / \mu \mathrm{L}$ de Iodeto de Propídio (BD Pharmingem, Santiago, EUA), incubadas por 15 minutos à $4^{\circ} \mathrm{C}$ protegidas da luz. Em seguida, foi acrescentado 1,0 mL de PBS gelado e a solução foi vortexada. Posteriormente os tubos foram centrifugados a $2000 \mathrm{rpm}$ por 6 minutos a temperatura ambiente (Eppendorf 5810R, Hamburgo, Alemanha), o sobrenadante foi descartado e o precipitado celular foi 
homogeneizado e ressuspenso em $500,0 \mu \mathrm{L}$ de solução de formaldeído diluído a $1 \% \mathrm{em}$ PBS (Formaldeído PA, Vetec, Brasil) e estocado em geladeira ao abrigo da luz até o momento da leitura no citômetro de fluxo. As células foram adquiridas e a intensidade de fluorescência foi captada pelo citômetro de fluxo no aparelho FacsCanto (Becton Dickinson, San Jose, EUA). Os dados foram analisados no CELLQuestTM (Becton Dickinson, San Jose, EUA). Para cada amostra foi realizada uma aquisição de 20.000 eventos. Os resultados foram fornecidos e analisados na forma de histogramas e em percentual da população celular com reação positiva para cada anticorpo.

4.4.1.c) Isolamento por ultracentrifugação: Um volume de $20,0 \mathrm{~mL}$ de meio de cultura referente ao cultivo de $2 \times 10^{6}$ células foi coletado e submetido à centrifugação por 30 minutos a $300 \times$ g para remoção de células em suspensão. O meio de cultura foi ultracentrifugado à $100.000 \times$ g por 3 horas em ultracentrífuga Himac CP80NX e rotor de ângulo fixo P50AT2 (Hitachi Koki Co, Tóquio, Japão) para sedimentação das VE. O sobrenadante foi descartado e os pellets cuidadosamente lavados com PBS e novamente sedimentados por ultracentrifugação à $100.000 \times \mathrm{g}$ por 20 minutos. As VE isoladas foram ressuspendidas em 2,0 mL de solução fisiológica e usadas para caracterização ou inoculação nos animais.

\subsubsection{Caracterizacão e quantificacão de VE}

4.4.2.a) Microscopia eletrônica: As características morfológicas e tamanho das VE foram analisadas por microscopia eletrônica, de acordo com o procedimento descrito previamente por Franquesa e colaboradores em 2014. As VE foram fixadas com 2,5\% de glutaraldeído e em seguida foram lavadas com PBS, ultracentrifugadas a 100.000×g por 20 minutos e incubadas com solução de acetato de uranila 2,0 \% para contraste. As 
amostras de VE foram dispostas em tela de cobre para análise no microscópio eletrônico de transmissão JEOL 1010 (Carl Zeiss NTS, Jena, Alemanha). As imagens foram capturadas no aumento de $15.000 \mathrm{X}$ e mensuradas com o software Image J (U.S. National Institutes of Health, Bethsda, EUA).

4.4.2.b) Análise de rastreamento das nanopartículas: A distribuição de tamanhos absolutos das VE foi determinada em aparelho Zetasizer Nano (Malvern Instruments, Malvern Worcertershire, UK), por análise de rastreamento de nanopartículas (Nanoparticle Tracking Analysis - NTA). Após o isolamento, o pellet das VE foi diluído em 2,0 mL de solução fisiológica filtrada e colocado em uma câmara de amostra para leitura do laser de $640 \mathrm{~nm}$. As amostras foram medidas em temperatura 23,0 $\pm 0,5^{\circ}$ C; viscosidade $0,91 \pm 0,03 \mathrm{cP}$, por 60 segundos a 25 quadros por segundo. Neste intervalo de tempo, foram capturadas 6 medidas para a análise do tamanho médio, que foi plotado em um histograma. O software utilizado para capturar e analisar os dados foi o NTA 2.0 Build 127. O tamanho e o desvio médio obtidos correspondem aos valores aritméticos calculados a partir dos tamanhos de todas as partículas analisadas pelo software.

4.4.2.c) Quantificação de proteínas totais: A quantidade de VE isolada é inferida indiretamente pela determinação da concentração proteica recuperada após processo de ultracentrifugação. A dosagem proteica das amostras foi realizada com o Kit Pierce 660nm (Thermo Fisher Scientific, Rockford, EUA), uma modificação do método de Bradford (Bradforf M, 1976). Para determinação da concentração proteica das amostras de VE, o pellet recuperado foi ressuspenso em 500,0 $\mu \mathrm{L}$ de $\mathrm{NaCl} 0,9 \%$, aos quais foram adicionados 7,5 mL da Solução de Pierce. Após homogeneização, as amostras foram incubadas por 5 minutos à temperatura ambiente e protegidas da luz. A absorbância das 
amostras em $660 \mathrm{~nm}$ foi determinada, e plotada contra uma curva padrão de BSA (na faixa de $12,5 \mu \mathrm{g} / \mathrm{mL}$ a $2000,0 \mu \mathrm{g} / \mathrm{mL}$ )e o rendimento proteico foi expresso em $\mu \mathrm{g} / \mathrm{mL}$. 


\subsection{Grupos experimentais}

Foram formados 4 grupos experimentais, com 8 animais em cada, descritos a seguir:

Grupo Controle: animais que receberam injeções intraperitoneais de Solução Fisiológica (SF).

Grupo FP: animais que receberam, por 30 dias, em dias alternados, injeções intraperitoneais de GC e tratados com veículo (SF) no $3^{\circ}$ e $10^{\circ}$ dias.

FP+CTmTA: animais que receberam, por 30 dias, em dias alternados, injeções intraperitoneais de GC e tratados com $2 \times 10^{6}$ CTmTA no $3^{\circ}$ e $10^{\circ}$ dias.

FP+VE: animais que receberam, por 30 dias, em dias alternados, injeções intraperitoneais de GC e de $30,0 \mu \mathrm{g}$ de $\mathrm{VE}$ no $3^{\circ} \mathrm{e}$ $10^{\circ}$ dias.

Todos os animais tiveram acesso ad libitum à água e ração normal.

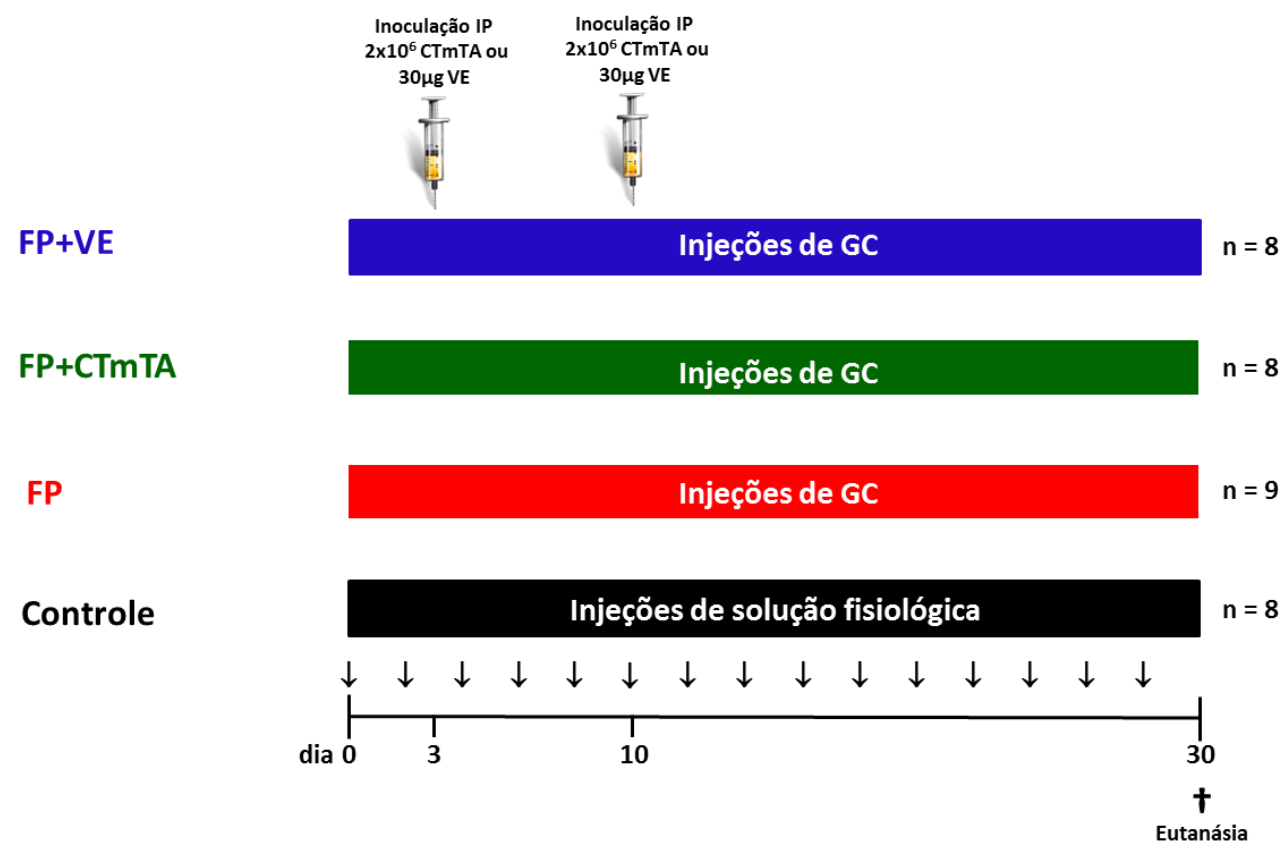

Figura 1: Desenho de estudo. Os animais foram divididos em 4 grupos: Controle, FP, $\mathrm{FP}+\mathrm{CTmTA}$ e FP+VE. No $30^{\circ}$ dia os animais foram submetidos à eutanásia para coleta de material biológico. $\mathrm{GC}=$ injeções alternadas de gluconato de clorexedina; CTmTA Células Tronco mesenquimais de Tecido Adiposo; VE = Vesículas Extracelulares; IP = intraperitoneal. 
Ao final do protocolo experimental, os animais foram anestesiados com injeção IP de solução de cloridrato de cetamina $(70,0 \mathrm{mg} / \mathrm{Kg})($ Ketamin-S, Cristália) e xilazina (11,0 mg/Kg) (Ronpun, Bayer), tiveram regiões do peritôneo parietal retirados e cuidadosamente dissecados. Parte das amostras do tecido foi imediatamente congelada em nitrogênio líquido e armazenada em freezer -80, enquanto outra parte foi fixada em formalina tamponada e destinada à análise histológica.

\subsection{Análise da função peritoneal}

\subsubsection{Ultrafiltracão (UF)}

O teste de equilíbrio peritoneal (PET), modificado, de 2 horas, foi realizado em todos os ratos no final dos experimentos. Cada rato recebeu injeção intraperitoneal de $0,09 \mathrm{ml} / \mathrm{g}$ de peso de solução de diálise peritoneal a 4,25\% de glicose (Baxter, Dianeal PD-2) e, 2 horas após da permanência da solução na cavidade peritoneal os animais foram anestesiados. A cavidade abdominal foi aberta ao longo da linha alba para coleta do líquido remanescente com seringa descartável, em condições estéreis. O volume de UF foi determinado como: (volume drenado) - (volume infundido). As amostras do efluente peritoneal foram centrifugadas a $2.000 \mathrm{rpm}$ por 10 minutos e armazenadas a $20^{\circ} \mathrm{C}$ até a dosagem da concentração de glicose.

\subsubsection{Transporte de Solutos}

A concentração de glicose no efluente drenado da cavidade peritoneal após 2 horas de permanência (D2) divida pela concentração da glicose na solução infundida (D0) - razão $\mathbf{D}_{2} / \mathbf{D}_{\mathbf{0}}$ - foi utilizada como uma medida para avaliação do transporte de solutos pela MP. 


\subsection{Análise da Espessura da Membrana Peritoneal (MP)}

\subsubsection{Preparo do tecido}

Após a retirada, os fragmentos de peritôneo foram lavados em solução fisiológica e mantidos em formalina tamponada, $\mathrm{pH}$ 7,4 por 48 horas para fixação. Em seguida, os fragmentos de tecido foram processados para desidratação e diafanização, foram inclusos em parafina e montados em blocos histológicos. Para a realização da coloração histológica cortes de $4 \mu \mathrm{m}$ de tecido foram fixados em lâminas e submetidos à desparafinização por aquecimento à $60^{\circ} \mathrm{C}$ por 30 minutos, seguido de incubação em 3 banhos sucessivos de 9 minutos em xilol (Merck, Darmstadt, Alemanha). Em seguida, o solvente foi removido do tecido por lavagem em 2 banhos de etanol absoluto e o tecido foi rehidratado por banhos sucessivos de etanol $96 \%$, etanol $70 \%$ e finalmente água destilada, até serem usadas para coloração histológica ou para imunohistoquímica.

\subsubsection{Análise histológica}

4.7.2.a) Coloração de Tricômio de Masson: Para análise da espessura e do índice de fibrose da MP dos animais dos diferentes grupos, os cortes foram submetidos à coloração de Tricrômio de Masson, que evidencia as proteínas da matriz extracelular e permite examinar a morfologia do estudo estudado. Os cortes foram preparados como descrito anteriormente, e em seguida foram incubados com Hematoxilina de Harris (Merck, Darmstadt, Alemanha) por 3 a 5 minutos, seguido por incubação em solução de Cromotrop por 25 minutos e lavagem em água destilada. O tecido foi desidratado e as lâminas foram montadas com meio permanente.

A análise histomorfométrica foi realizada a partir de imagens obtidas de toda a extensão do fragmento do peritôneo de cada animal, onde cada imagem correspondia a 
um campo microscópico em aumento de 200 X. Para cada campo, a espessura da MP foi medida em três pontos diferentes e uma média foi calculada. A espessura média da MP de cada animal foi calculada a partir das médias calculadas para cada campo analisado. Para este procedimento utilizamos imagens digitalizadas e software de análise Image Pro Plus Software 7.0, Media Cybernetics Inc, Bethesda, EUA).

\subsection{Análise do Infiltrado Celular na Membrana Peritoneal}

\subsubsection{Imunohistoquímica}

4.8.1.a) Macrófagos, Linfócitos $T$ e Miofibroblastos: Para a identificação e quantificação de macrófagos, linfócitos e miofibloblastos infiltrantes na MP dos animais dos grupos estudados, foram realizados experimentos de imunohistoquímica pelo método LSAB-AP (Labeled Streptavidin - Biotin - Alcaline Phosphatase Dako, Carpinteria, USA). Após serem desparafinizados e rehidratados como descrito no item anterior, os cortes de tecido da MP foram submetidos à recuperação antigênica por aquecimento em tampão citrato 10,0 mM, pH 6,0, em forno de micro-ondas a $2400 \mathrm{~W}$, durante15 minutos. Após o resfriamento da solução, os fragmentos de tecido foram lavados em água destilada e em seguida em solução salina tamponada com Tris (tampão TBS, Tris 50,0 mM, $\mathrm{NaCl} 0,9 \% \mathrm{pH}$ 7,6). Antes da reação com os anticorpos específicos, os fragmentos de tecido foram submetidos ao bloqueio da biotina endógena, por incubação à temperatura ambiente por 15 minutos com uma solução de avidina $\mathrm{D}$, seguido por incubação em solução de biotina (Kit Biotin Block, Spring Bioscience, Plessanton, EUA). Em seguida, os cortes foram incubados por 30 minutos em Protein Block Solution (Spring Bioscience, Plessanton, EUA) para o bloqueio de antígenos inespecíficos no tecido. 
A incubação com os anticorpos específicos foi realizada a $4^{\circ} \mathrm{C}$, por $12 \mathrm{~h}$, em diluições previamente padronizadas: macrófagos 1:200 (mouse anti-rat CD68, ED1, Serotec, Raleigh, EUA); linfócitos 1:100 (mouse anti-rat CD43, w3/13, Serotec, Raleigh, EUA) e miofibroblastos 1:800 (mouse anti-Smoth Muscle Actin, 1A4, Sigma Chemical CO, St. Louis, EUA). Ao final do período de incubação, os cortes foram lavados com TBS para retirar o excesso de anticorpo e incubados com o anticorpo secundário biotinilado (Universal Biotinilated Link Dako, Carpinteria, EUA) por 30 minutos, em temperatura ambiente. Após nova lavagem em TBS foi realizada incubação com o complexo contendo a enzima fosfatase alcalina (Streptavidin-Biotin-Alcaline Phosphatase Complex Dako, Carpinteria, EUA) por 30 minutos em temperatura ambiente. Após lavagem para remoção do complexo não ligado, os cortes foram incubados por 5 a 10 minutos com uma solução substrato da fosfatase alcalina contendo o corante Fast Red (naftol fosfato 0,54 mM, levamisole 2,0 mM, Fast Red 0,01\% em Tris $0,1 \mathrm{M} \mathrm{pH} 8,2$ ), que confere uma cor vermelha às células expressando o antígeno estudado. Ao final da revelação, os fragmentos de tecido foram contra corados em hematoxilina de Mayer (Merck, Darmstadt, Alemanha) por 2 minutos, lavados em água destilada e montados com gelatina glicerinada de Kaiser (Merck, Darmstadt, Alemanha).

\subsection{1.b) Quantificação de Macrófagos, Linfócitos $T$ e Miofibroblastos: Para} quantificação, foi considerada a área total da MP de cada fragmento analisado. Para todos os marcadores, inicialmente foram capturadas em microscópio sob aumento de 200x quantas imagens fossem necessárias para analisar toda a MP da amostra. Em seguida, com o auxílio do software ImagePro Plus 7.0 (Media Cybernetics Inc., Bethesda, EUA) a área da MP de cada imagem foi calculada em $\mathrm{mm}^{2}$. A soma das áreas 
da MP, determinada em cada imagem, correspondeu à àrea total analisada para cada animal. Para macrófagos e linfócitos o número de células marcadas foi contado em cada imagem e somado para obter o valor total, expresso como células $/ \mathrm{mm}^{2}$. Para miofibroblastos, a expressão de $\alpha$-SMA foi mensurada como área marcada no peritôneo, descontando a marcação constitutiva de vasos, e expressa como \% da área da MP analisada.

4.8.1.c) Densidade Vascular: Para a avaliação da neoangiogênese na MP foi determinado o índice de densidade vascular, definido como o número de vasos sanguíneos na camada submesotelial dividido pela área da MP. Para cada animal foi realizada imunohistoquímica para $\alpha$-SMA como descrito anteriormente e fotos de toda a extensão do peritôneo foram tiradas a partir de um microscópio sob aumento de $200 \mathrm{X}$. A quantificação, expressa em número de vasos $/ \mathrm{mm}^{2}$, foi feita a partir da contagem do número de vasos positivos para $\alpha$-SMA na zona submesotelial e o valor obtido foi ajustado pela área da MP. A média de cada animal foi calculada a partir dos índices de densidade vascular de todos os respectivos campos microscópicos. Utilizamos o software Image-Pro Plus 7.0 (Media Cybernetics Inc., Bethesda, EUA).

\subsection{PCR em tempo real}

\subsubsection{Extracão de RNA}

O RNA total foi extraído da MP com o reagente Trizol (Invitrogen, Carlsbad, EUA), seguindo-se o protocolo sugerido pelo fabricante. Cada 100,0 mg de tecido foi homogenizado com 1,0 mL de Trizol com auxílio de um dispersador de tecidos (IKA Labortechnik Ultra Turrax T25 Janke \& Kunkel, Staufen Alemanha). A cada mL de homogenato, foram adicionados 200,0 $\mu \mathrm{L}$ de clorofórmio (Merck, Darmstadt, 
Alemanha), a mistura foi novamente homogeneizada e mantida por 3 minutos a temperatura ambiente.

Após a incubação, a mistura foi centrifugada a $12.000 \times \mathrm{g}$ a $4^{\circ} \mathrm{C}$ por 20 minutos. A fase superior contendo RNA foi transferida para um microtubo de 2,0 $\mathrm{mL}$ contendo o mesmo volume de isopropanol gelado (Sigma Chemical Co, Saint Louis, EUA). As amostras foram centrifugadas a $12.000 \times \mathrm{g}$ durante 10 minutos, o sobrenadante foi descartado, o RNA foi ressuspendido em 1,0 mL de etanol 70\% (Merck, Darmstadt, Alemanha) e centrifugado novamente a $12.000 \times \mathrm{g}$ por 10 minutos. Este procedimento foi repetido e o pellet foi resuspendido com 50,0 $\mu \mathrm{L}$ de água ultrapura (Invitrogen, Life Technologies, Lowell, EUA).

A quantidade de RNA obtido foi determinada através da leitura, em espectrofotômetro (NanoDrop, Thermo Fisher Scientific, Marietta, EUA) medindo-se absorbância nos comprimentos de onda 260 e 280 nm. Foi calculada a concentração de RNA, expresso em $\mu \mathrm{g} / \mathrm{mL}$, a partir da absorbância a $260 \mathrm{~nm}$. A leitura de 1 OD corresponde a uma solução pura de RNA em fita-simples na concentração de 40,0 $\mu \mathrm{g} / \mathrm{mL}$. A leitura a $280 \mathrm{~nm}$ foi utilizada para determinar a contaminação das amostras com proteínas. A análise foi feita baseando-se na razão entre as absorbâncias a $\operatorname{Abs}_{260 \mathrm{~nm}} / \mathrm{Abs}_{280 \mathrm{~nm}}$ e o valor aceitável foi de 1,7 a 2,0. As amostras de RNA total extraídas foram utilizadas imediatamente para a produção de cDNA.

\subsubsection{Transcricão Reversa}

Todos reagentes utilizados para a reação de síntese do DNA complementar (cDNA) foram da marca Promega (Promega, San Luis Obispo, EUA). Um microlitro de oligo dT primer $(500,0 \mu \mathrm{g} / \mathrm{ml})$ foi misturado a $14,0 \mu \mathrm{l}$ da amostra de RNA previamente diluída a 50,0 ng/ $\mu$ l. A solução foi aquecida a $70^{\circ} \mathrm{C}$ por 5 minutos e resfriada em gelo 
por 5 minutos. Em seguida, foram acrescentados 5,0 $\mu$ l de tampão [5X] (Tris-HCl 250 $\mathrm{mM}$ pH 8,3, KCL $375 \mathrm{mM}, \mathrm{MgCl} 215 \mathrm{mM}), 2,75 \mu \mathrm{l}$ de água ultrapura, 1,25 $\mu 1$ de dNTP Mix (10mM de dATP, dGTP, dCTP e dTTP) e 1,0 $\mu \mathrm{l}$ (200U) da enzima transcriptase reversa M-MLV (Moloney Murine Leukemia Virus). A reação foi realizada a $42^{\circ} \mathrm{C}$ por 50 minutos, passando posteriormente por um período de 15 minutos a $70^{\circ} \mathrm{C}$ para a inativação da enzima. $\mathrm{O}$ cDNA foi mantido em freezer a $-20^{\circ} \mathrm{C}$ até a realização da reação de PCR em tempo real.

\subsubsection{PCR em tempo real}

Primers para a obtenção de amplicons com no máximo 250 pb, foram confeccionados (Tabela 3). Para a PCR em tempo real foi utilizado o kit SYBR GreenEr qPCR SuperMix Universal (Invitrogen, Carlsbad, EUA) e todas as reações foram realizadas em duplicatas, no equipamento StepOnePlus ${ }^{\mathrm{TM}}$ Real-Time PCR System (Applied Biosystems, Foster City, EUA)

Um microlitro de cDNA foi acrescentado a 7,5 $\mu \mathrm{L}$ de mix do kit, 0,6 $\mu \mathrm{L}$ de primer foward $(10 \mu \mathrm{M}), 0,6 \mu \mathrm{L}$ de primer reverse $(10 \mu \mathrm{M}), 5,75 \mu 1$ de água deionizada e $0,15 \mu \mathrm{l}$ de Rox. A mistura foi aquecida a $50^{\circ} \mathrm{C}$ por 10 minutos e depois a $95^{\circ} \mathrm{C}$ por 5 minutos, seguindo 40 ciclos de $95^{\circ} \mathrm{C}$ por 15 segundos, $60^{\circ} \mathrm{C}$ por 30 segundos e $72^{\circ} \mathrm{C}$ por 30 segundos. Todas as reações foram realizadas em duplicatas.

A expressão gênica foi determinada como a expressão relativa entre o gene alvo e o gene endógeno $18 \mathrm{~S}$, calculadas pelo software do StepOnePlus ${ }^{\mathrm{TM}}$ Real-Time PCR System (Applied Biosystems, Foster City, EUA), a partir dos cycle threshold (Ct) das reações. Para o cálculo dos resultados do PCR em tempo real foi utilizado o método $\Delta \mathrm{Ct}$, que utiliza as fórmulas:

$\Delta \mathrm{Ct}=\mathrm{Ct}$ gene alvo $-\mathrm{Ct}$ gene endógeno

$\Delta \Delta \mathrm{Ct}=\Delta \mathrm{Ct}$ do gene alvo $-\Delta \mathrm{Ct}$ do gene endógeno 
A variação na taxa da expressão gênica foi calculada como $2^{-\Delta \Delta C t}$ (Livak et al., 2001).

Tabela 3. Primers utilizados para os experimentos de PCR em tempo real

\begin{tabular}{ll}
\hline Gene alvo & \multicolumn{1}{c}{ Primers } \\
\hline $18 S$ & $\begin{array}{l}\text { Sense 5' AGGAGTACGATGAGTCCGGCCC 3' } \\
\text { Antisense 5' GCAGCTCAGTAACAGTCCGCCT3' }\end{array}$ \\
\hline TNF- $\alpha$ & $\begin{array}{l}\text { Sense 5'TGGCCCAGACCCTCACACTCA3' } \\
\text { Antisense 5'GGCTCAGCCACTCCAGCTGC3' }\end{array}$ \\
\hline Fibronectina & $\begin{array}{l}\text { Sense 5'TGACCCAGACTTACGGTGGCA3' } \\
\text { Antisense 5'GGAGTAGAAGGTCCTACCGTTGTAGTG3' }\end{array}$ \\
\hline TGF- $\beta$ & Sense 5'CAACCCGGGTGCTTCCGCAT3' \\
& Antisense 5'TGCTCCACCTTGGGCTTGCG3' \\
\hline VEGF & Sense 5'ACTGTGAGCCTTGTTCAGAGCGG3' \\
& Antisense 5'TCAAGCTGCCTCGCCTTGCA3' \\
\hline FSP-1 & Sense 5'GGCAACGAGGGTGACAAGTT3' \\
& Antisense 5'CCCTGGTCAGTAGTCCCTTGA3' \\
\hline SMAD 3 & Sense 5'TCAACGGAACTTGGGAATGAG3' \\
& Antisense 5'GTAGTGCGGAGCTCTCCTTCA3' \\
\hline Smad7 & Sense 5'CCTGGCCGGTGTAAATGTCT3' \\
& Antisense 5'GCGGATCCCTTGGAAAGG3'
\end{tabular}

\subsection{Análise Estatística}

A análise estatísica foi baseada na comparação de grupos, utilizando para os cálculos o software GraphPad Prism versão 5.01 (Graphpad Software, La Jolla, EUA). Inicialmente as diversas variáveis foram testadas para normalidade e então o teste ANOVA com pós-teste de Tukey foi aplicado. Em relação aos resultados de PCR em tempo real, após a obtenção dos valores de cicle trashold $(\mathrm{Ct})$ de cada amostra referente ao gene alvo, foi determinada a diferença de $\mathrm{Ct}$ entre o gene constitutivo e o gene de interesse e os valores foram normalizados pelo cálculo do seu logaritmo $\left(2^{-\Delta \Delta C t}\right) \mathrm{O}$ erro padrão foi calculado a partir dos valores normalizados de Ct. 
Todos os resultados foram apresentados como média \pm erro padrão. A significância estatística foi considerada uma vez que $p<0,05$. Foram utilizados símbolos distintos para designar as diferentes comparações. Sendo que o símbolo * foi utilizado para comparar com o Grupo Controle, o símbolo \# para comparar com o Grupo FP e o símbolo § para comparar com o Grupo CTmTA. 


\section{RESULTADOS}

\subsection{Isolamento e caracterização de CTmTA}

\subsubsection{Cultura de CTmTA}

O isolamento das CTmTA de ratos Wistar produziu alto rendimento. Nos primeiros dois dias de cultura, observou-se que o tecido adiposo propiciou uma cultura heterogênea, composta por células arredondadas, não aderentes e micelas lipídicas no sobrenadante da cultura. A partir do sétimo dia, a população celular estava mais homogênea, com predominância de células aderentes, de morfologia fibroblastóide e com formação de colônias. As trocas do meio de cultura propiciaram a remoção das células não aderentes e das micelas lipídicas e, mediante a visualização de $80 \%$ de confluência celular nas placas, as células foram tripsinizadas e uma nova subcultura foi estabelecida. Durante todo o período de cultivo, as células aderentes mantiveram-se fenotipicamente estáveis e com viabilidade de 97\% (Figura 2).
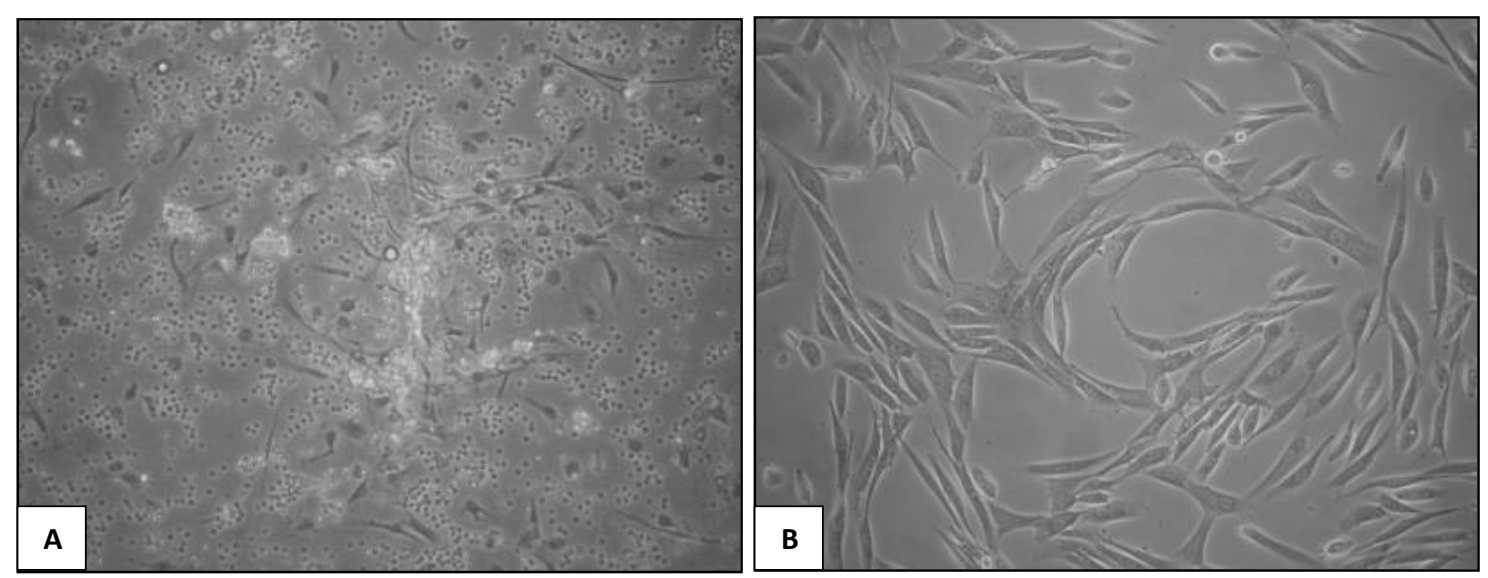

Figura 2. Imagem do cultivo celular de CTmTA de ratos Wistar nas passagens: (A) P0, (B) P4, $400 x$ 


\subsubsection{Citometria de Fluxo - Imunofenótipo mesenquimal}

As células tronco mesenquimais derivadas de tecidos adiposo (CTmTA) in vitro foram analisados por citometria de fluxo na $4^{\mathrm{a}}$ passagem. As CTmTA expressaram marcação positiva, de alta intensidade para CD29, CD44, CD90 e CD105 e marcação negativa, de baixa intensidade, para o marcador Pan-leucocitário CD45 (Figura 3).
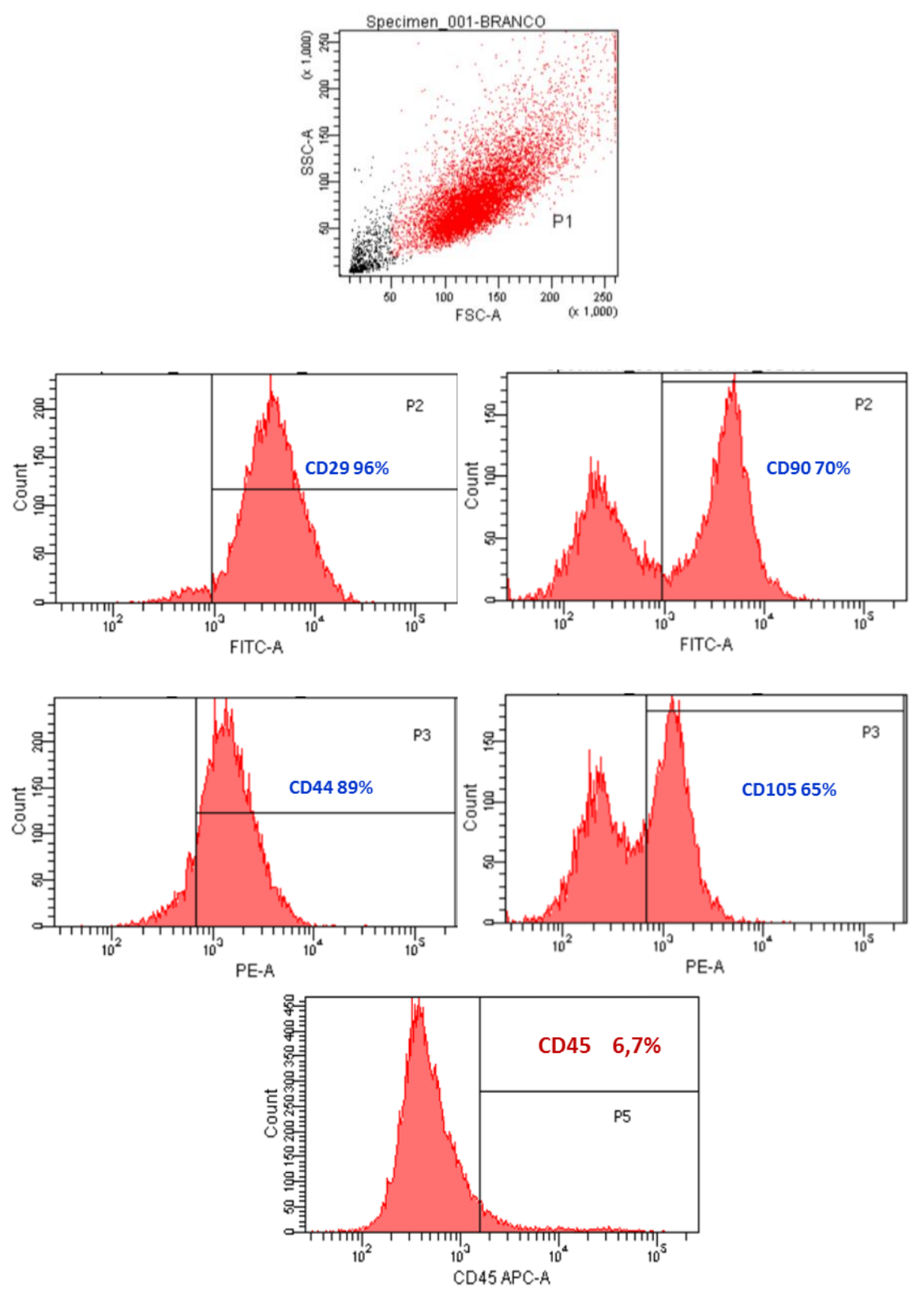

Figura 3. Citometria de fluxo para caracterização do fenótipo mesenquimal das CTmTA em P4. Porcentagem dos marcadores positivos CD29, CD105, CD90 e CD44 e marcador negativo para CD45 


\subsubsection{Caracterizacão por Diferenciação Celular}

Na Figura 4, são apresentados os resultados da diferenciação adipogênica, osteogênica e condrogênica, realizados com células na $4^{\mathrm{a}}$ passagem. Na Figura 4A, as células foram cultivadas apenas com meio de crescimento DMEM-LOW $+10 \%$ de SBF, na ausência de indutores de diferenciação. Na Figura 4B, pode ser observada a diferenciação osteogênica das células, após o cultivo em meio suplementado com dexametasona, $\beta$-glicerol fosfato e ácido ascórbico; notam-se depósitos de cálcio pela coloração com corante vermelho de Alizarina. Na Figura 4C, as células foram cultivadas com indutor adipogênico, suplementado com insulina e dexametasona, e coradas em Oil Red, corante que evidencia depósitos de lipídeos no citoplasma, acumuladas em células adiposas. Na Figura 4D, as células foram cultivadas em meio de diferenciação indutor condrogênico, observando-se a presença de matriz extracelular de condroblastos, coradas com Alien Blue.
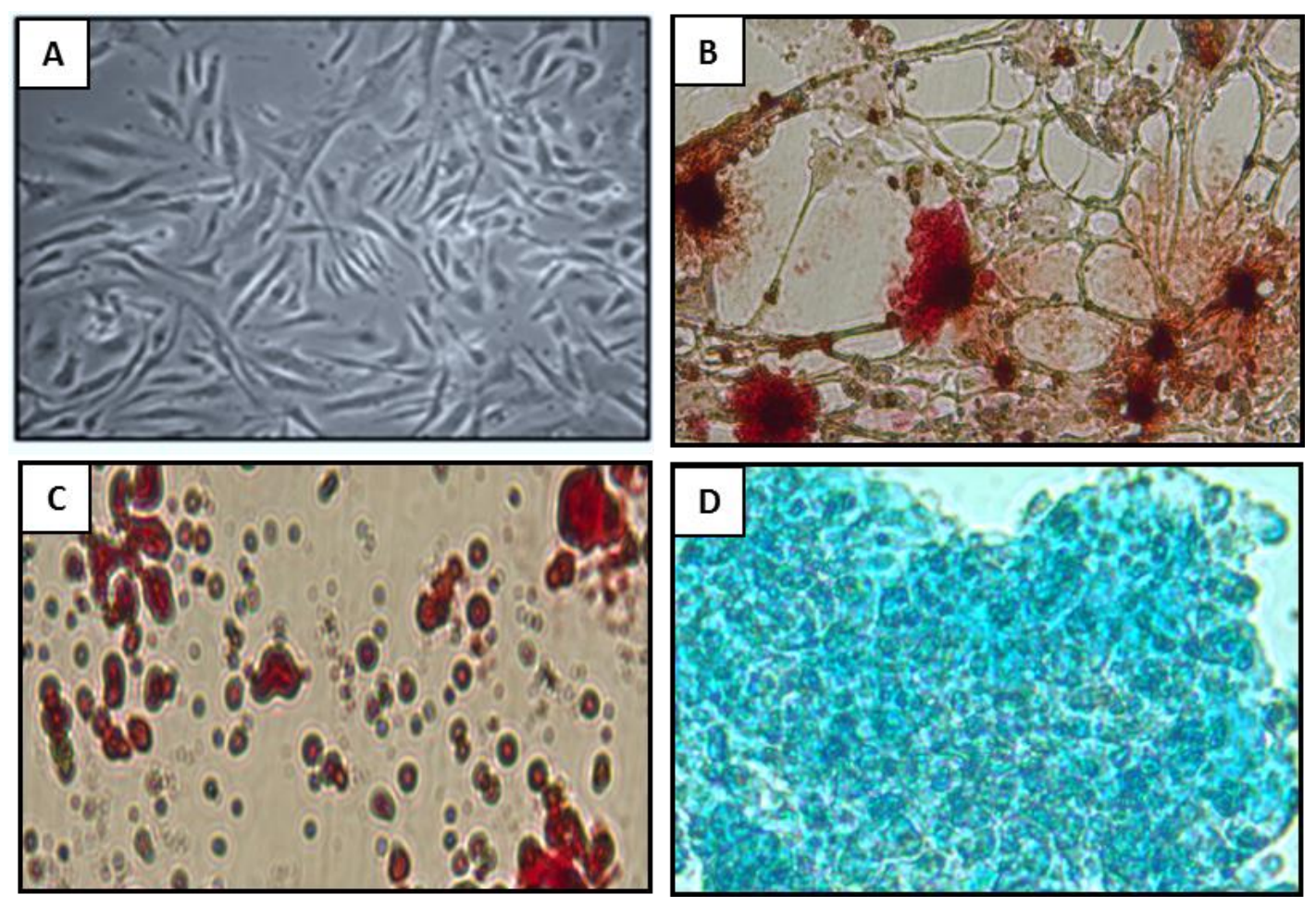

Figura 4. Diferenciação in vitro das CTmTA na $4^{\mathrm{a}}$ passagem. Aumento de $400 \mathrm{x}$ 


\subsection{Isolamento e Caracterização de VE}

O isolamento das VE foi feito por ultracentrifugação e a caracterização foi realizada por microscopia eletrônica de transmissão, rastreamento de nanopartículas e análise da concentração das proteínas totais. O conjunto das técnicas para caracterização das VE está apresentado a seguir, com resultados antes e após a padronização do isolamento.

\subsubsection{Isolamento de VE a partir de CTmTA}

O isolamento das VE foi feito a partir das CTmTA de ratos Wistar na $4^{\mathrm{a}}$ passagem. Após serem mantidas em cultura por 24 horas sem soro fetal bovino (SBF), foi realizada a análise da viabilidade celular e testes de apoptose. As CTmTA apresentaram 97;0 $\pm 0,5 \%$ de viabilidade celular analisadas pelo método de exclusão por Trypan Blue e $4,0 \pm 0,8 \%$ de células apoptóticas, analisadas por citometria de fluxo pelo método de Iodeto de Propídio (figura 5).
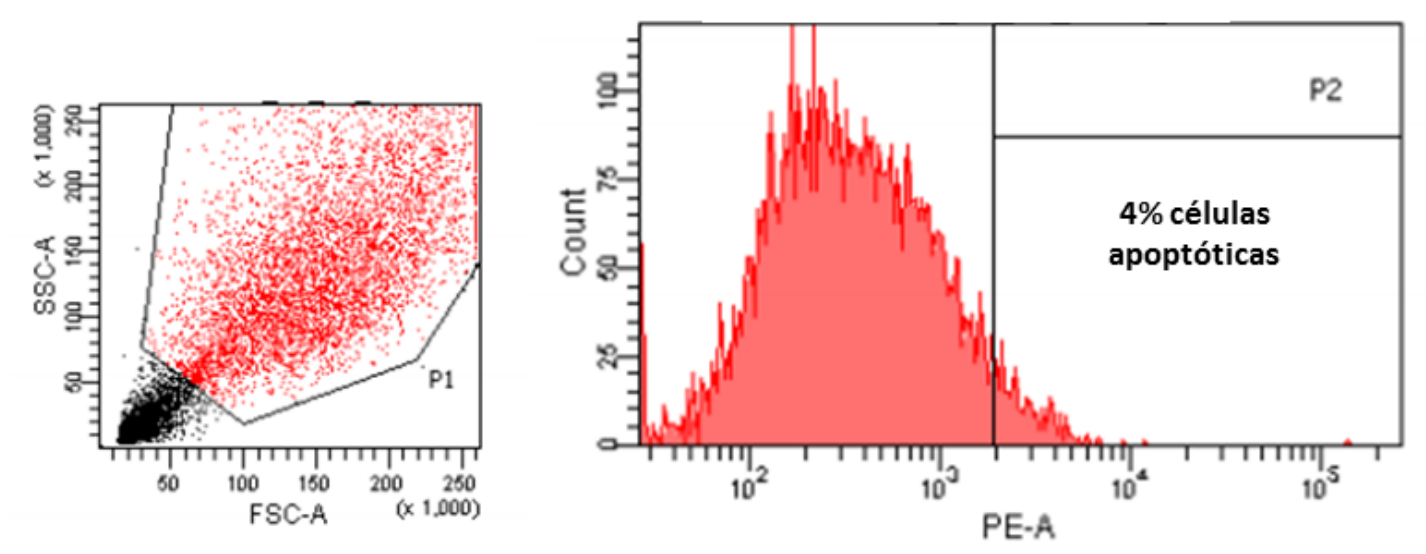

Figura 5. Citometria de fluxo para detecção de células apoptóticas. Análise da porcentagem de CTmTA apoptóticas após ausência de SFB no meio de cultura por 24h 


\subsubsection{Microscopia eletrônica de VE isoladas de CTmTA}

A análise da morfologia e do tamanho das VE foi feita por microscopia eletrônica. As imagens da Figura 6 representam as VE no processo de padronização, após isolamento.

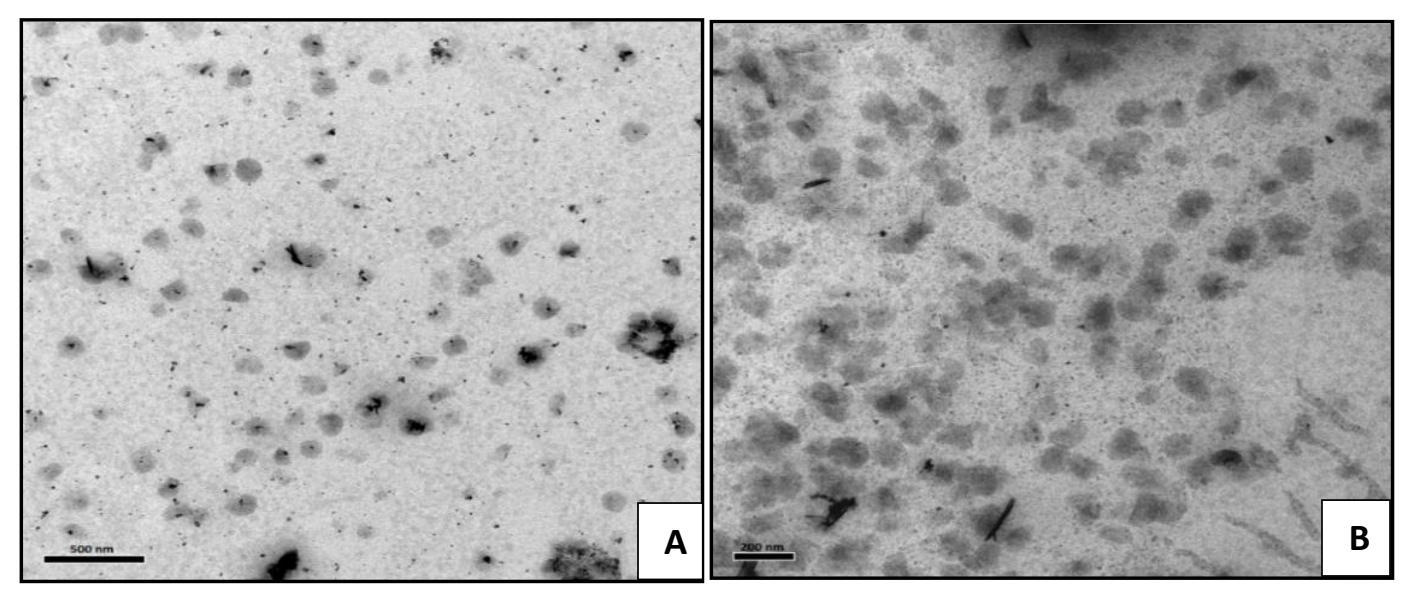

Figura 6. Análise da morfologia e tamanho das VE por microscopia eletrônica. A figura A representa uma amostra sem padronização. As VE apresentam morfologia heterogênea, com tamanho irregular de até $500 \mathrm{~nm}$ e grande quantidade de precipitado celular. A figura $\mathbf{B}$ representa uma amostra com isolamento padronizado. As VE apresentam morfologia homogênea tamanho com padrão uniforme de até $200 \mathrm{~nm}$ e pouco precipitado celular. Aumento de $15000 x$.

\subsubsection{Análise da distribuicão do tamanho das VE}

A análise da distribuição do tamanho absoluto das VE foi feita pela técnica de rastreamento das nanopartículas (NTA). A partir do resultado de seis leituras das amostras, foi calculada uma média da distribuição do tamanho das VE, representada em um gráfico de histograma. Esta análise foi essencial para padronização do protocolo de isolamento. A partir dela, foi feita alterações importantes no protocolo de isolamento, de modo a obter um padrão de pureza, que influenciava diretamente nos outros métodos de caracterização, tanto na concentração proteica como na microscopia eletrônica. Foi observado variações de tamanho das VE, como demonstrado na Figura 7, após 
acrescentar etapas de lavagens no protocolo de isolamento, concluiu-se que a variação de tamanho ocorria devido a influências das vesículas derivadas do SFB. Os resultados representados na Figura 8, indica que a após a padronização do protocolo de isolamento das VE, foram obtidas amostras homogêneas, de boa qualidade (referenciada pelo índice de polidispersibilidade, $\mathrm{Pdl}=1$ ) e com tamanho com padrão regular.

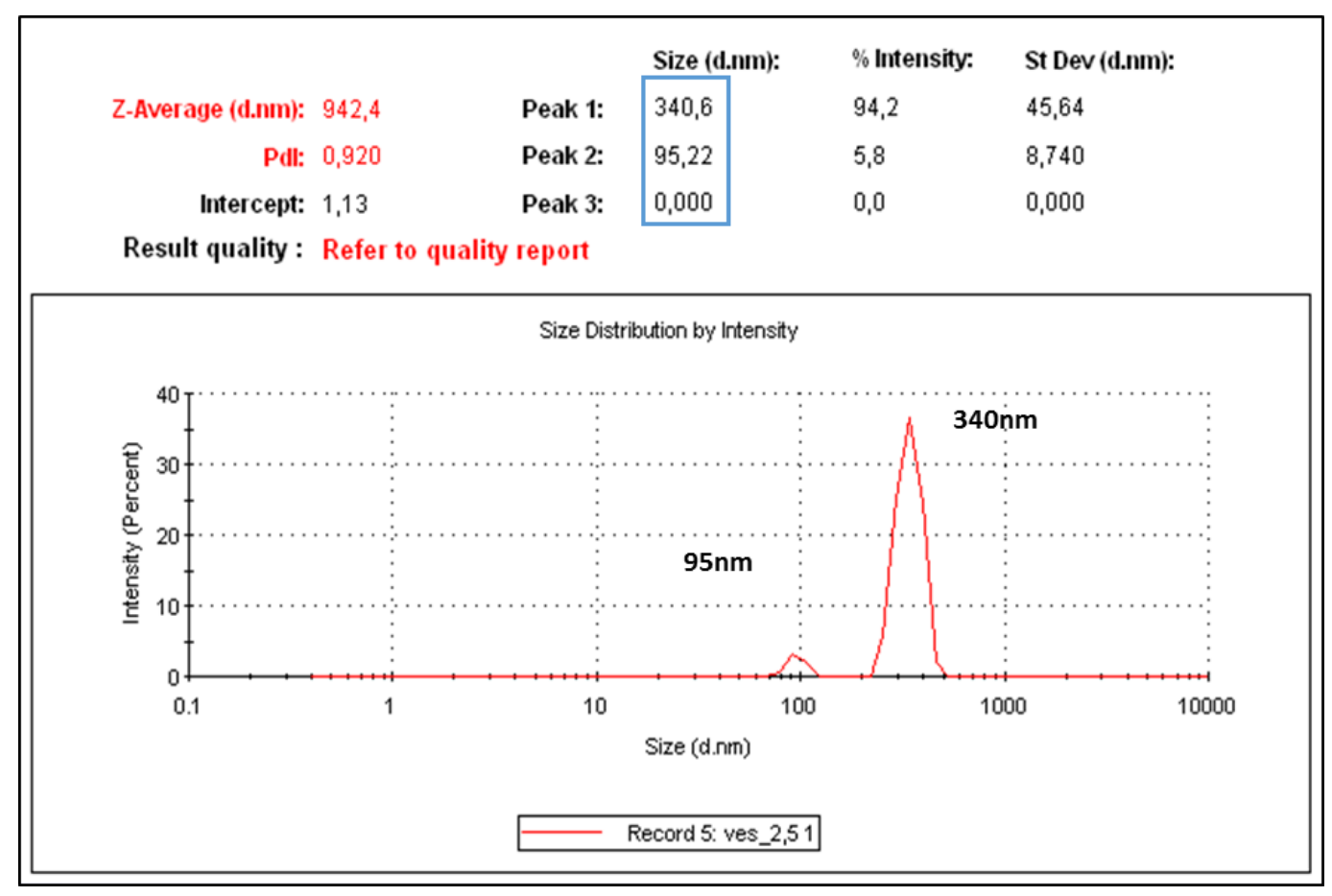

Figura 7. Distribuição de tamanho das VE pelo método de rastreamento de nanopartículas. As amostras de VE tem tamanhos irregulares e apresentam falta de qualidade $(\operatorname{PdL}<1)$ 


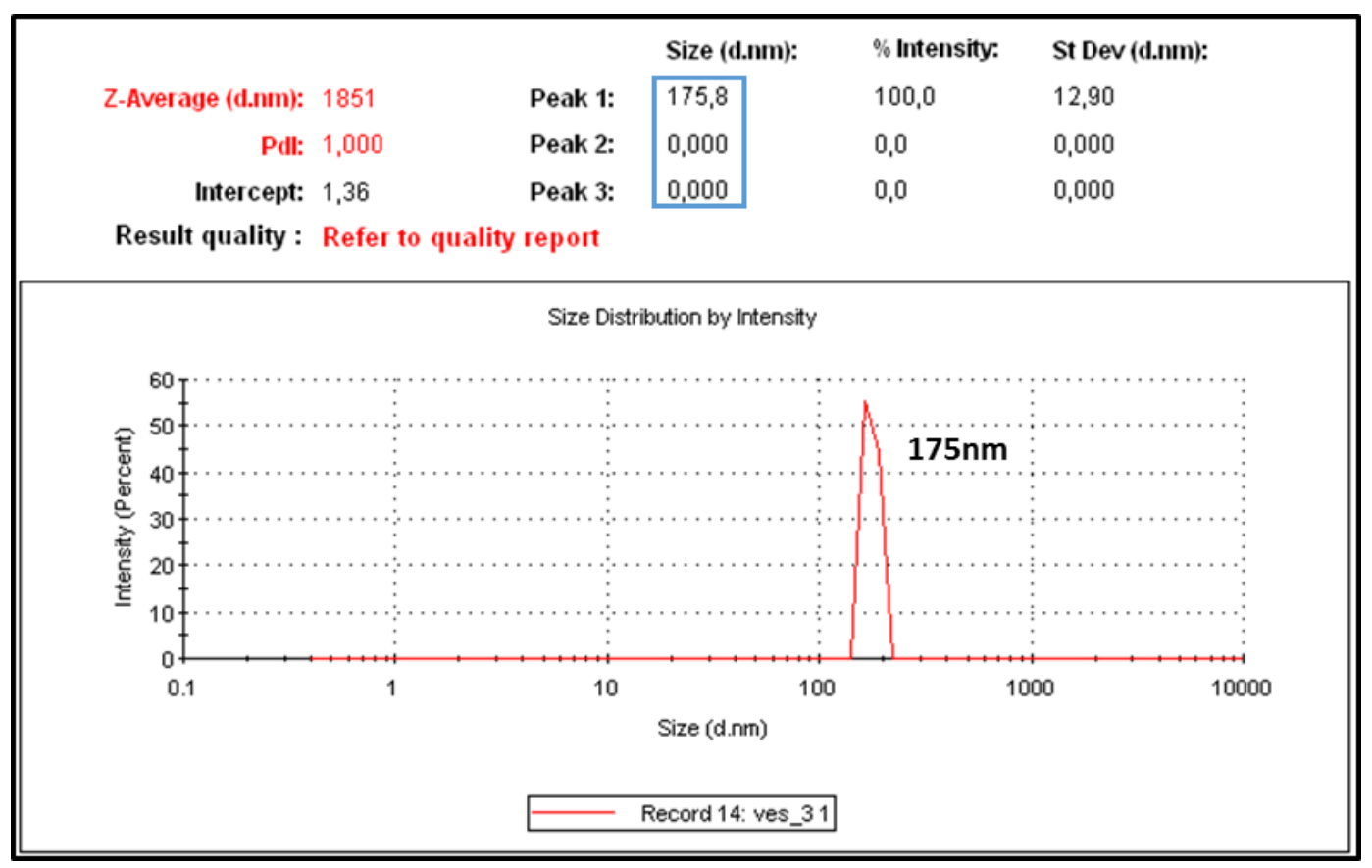

Figura 8: Distribuição de tamanho das VE pelo método de rastreamento de nanopartículas padronizado para tamanho e qualidade (referência $\mathrm{Pdl}=1$ ) da amostra

\subsubsection{Análise proteica das VE}

A quantidade de VE isoladas foi inferida indiretamente pela determinação da concentração proteica da amostra após o processo de ultracentrifugação. Estabeleceu-se utilizar amostras de VE que continham $30 \mu \mathrm{g} / \mathrm{mL}$ de proteína. Para tanto, foram analisadas amostras de VE de 20,0 mL obtidas a partir do cultivo de CTmTA plaqueadas em diferentes quantidades. Assim, foi estabelecida uma relação do número de células que deveria ser cultivada para a obtenção da concentração proteica determinada.

Os dados obtidos previamente à padronização estão representados na Tabela 4A. O volume de meio de cultura foi $20,0 \mathrm{~mL}$, com variação no número de células. Nesta etapa, foi determinado que $30 \mu \mathrm{g} / \mathrm{mL}$ de proteína seriam obtidos do cultivo de $2 \times 10^{6}$ 
CTmTA em volume de 20,0 mL de meio de cultura. Após a determinação do número de células e do volume que seriam utilizados foi analisado a reprodutibilidade do procedimento. Para isso, foram realizados isolamentos de VE de 3 amostras por dia. Cada amostra da Tabela B representa um dia de isolamento, até que o método fosse considerado padronizado.

Tabela 4. Análise proteica das VE obtidas das CTmTA. Na tabela A observa-se amostras em triplicata de concentrações proteicas proporcionais a diferentes quantidades de células. Foi padronizado o uso de $2 \times 10^{6}$ de CTmTA para obtenção de $30 \mu \mathrm{g} / \mathrm{mL}$ de VE. Na tabela B observa-se homogeneidade entre número de células estabelecido e a concentração proteica resultante. Dados apresentados como média \pm erro médio padrão

\begin{tabular}{|c|c|c|c|c|c|}
\hline \multirow{2}{*}{ Amostras } & \multirow[b]{2}{*}{ Número de células } & \multirow{2}{*}{$\begin{array}{c}\text { Concentração } \\
\text { Proteica } \\
(\mu \mathrm{g} / \mathrm{mL})\end{array}$} & \multicolumn{3}{|l|}{ B } \\
\hline & & & \multirow{2}{*}{ Amostras } & \multirow{2}{*}{ Número de células } & \multirow{2}{*}{$\begin{array}{c}\text { Concentração } \\
\text { Proteica } \\
(\mu \mathrm{g} / \mathrm{mL})\end{array}$} \\
\hline 1 & CTmTA $5 \times 10^{6}$ & 100,7 & & & \\
\hline 2 & CTmTA $5 \times 10^{6}$ & 77,3 & 11 & CTmTA $2 \times 10^{6}$ & 28,8 \\
\hline 3 & CTmTA $5 \times 10^{6}$ & 73,0 & 12 & CTmTA $2 \times 10^{6}$ & 28,4 \\
\hline 4 & CTmTA $4 \times 10^{6}$ & 60,2 & 13 & CTmTA $2 \times 10^{6}$ & 32,4 \\
\hline 5 & CTmTA $4 \times 10^{6}$ & 60,2 & 14 & CTmTA $2 \times 10^{6}$ & 27,1 \\
\hline 6 & CTmTA $3 \times 10^{6}$ & 54,3 & 15 & CTmTA $2 \times 10^{6}$ & 33,3 \\
\hline 7 & CTmTA $3 \times 10^{6}$ & 64,5 & & MÉDIA & 30,0 \\
\hline 8 & CTmTA $2 \times 10^{6}$ & 25,2 & & SEM & 1,2 \\
\hline 9 & CTmTA $2 \times 10^{6}$ & 32,4 & & & \\
\hline 10 & CTmTA $2 \times 10^{6}$ & 26,1 & & & \\
\hline
\end{tabular}




\subsection{Resultados dos Grupos Experimentais}

\subsubsection{Mortalidade e evolucão ponderal}

Não houve mortalidade em nenhum dos grupos experimentais ao longo de todo o tempo de seguimento do estudo. Todos os animais evoluíram com ganho de peso, sem diferença entre os grupos (Tabela 5, Figura 9).

Tabela 5. Evolução ponderal dos grupos experimentais

\begin{tabular}{llll}
\hline & $\begin{array}{c}\text { Peso inicial } \\
(\mathrm{g})\end{array}$ & $\begin{array}{c}\text { Peso final } \\
(\mathrm{g})\end{array}$ & $\begin{array}{c}\Delta \text { Peso } \\
(\mathrm{g})\end{array}$ \\
\hline Controle & $305 \pm 12$ & $411 \pm 2$ & $106 \pm 12$ \\
$\boldsymbol{F P}$ & $280 \pm 8$ & $394 \pm 10$ & $115 \pm 11$ \\
$\boldsymbol{C T m T A}$ & $255 \pm 2$ & $375 \pm 7$ & $120 \pm 6$ \\
$\boldsymbol{V E}$ & $266 \pm 2$ & $396 \pm 9$ & $130 \pm 7$ \\
\hline
\end{tabular}

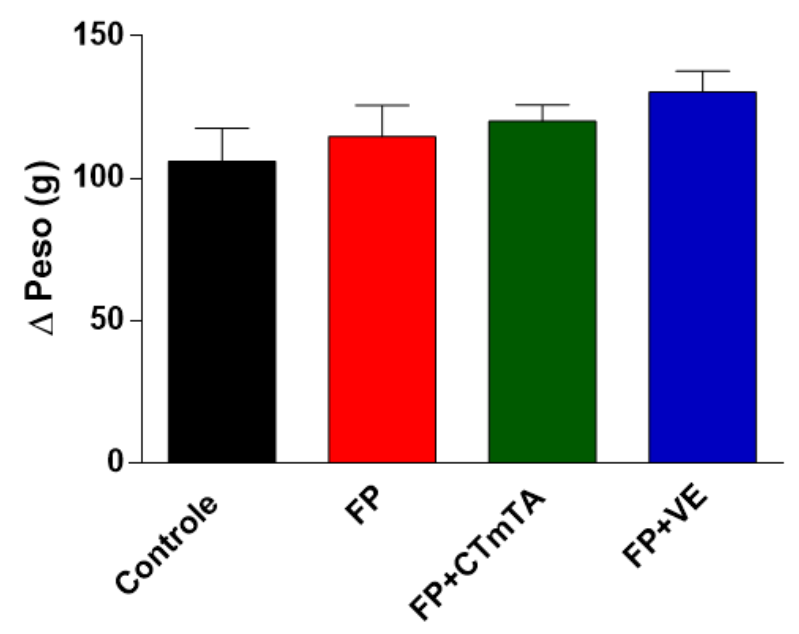

Figura 9. Peso corpóreo médio dos animais dos grupos estudados, ao final do protocolo experimental. $\mathrm{FP}=$ grupo com Fibrose Peritoneal; $\mathrm{FP}+\mathrm{CTmTA}=$ grupo com fibrose peritoneal, tratado com Células Tronco mesenquimais de Tecido Adiposo; grupo FP+VE= grupo com fibrose peritoneal, tratado com VE 


\subsubsection{Fibrose Peritoneal}

Os animais do grupo Controle apresentaram MP preservada, sem alteração significativa na espessura e na sua morfologia até o final do estudo. Os animais do grupo FP apresentaram um aumento significativo na espessura da MP, quando comparado com o grupo Controle. Os tratamentos com CTmTA e VE reduziram significantemente a espessura da MP, apresentando valores similares aos do grupo controle (Tabela 6, Figura 10).

Tabela 6. Quantificação da espessura da MP

\begin{tabular}{lc}
\hline & $\begin{array}{c}\text { Espessura } \\
(\mu \mathrm{m})\end{array}$ \\
\hline Controle & $23,0 \pm 2,1$ \\
$\boldsymbol{F P}$ & $64,8 \pm 14,1^{* *}$ \\
$\boldsymbol{F P}+\boldsymbol{C T m T A}$ & $21,4 \pm 2,4^{\# \#}$ \\
$\boldsymbol{F P}+\boldsymbol{V E}$ & $24,3 \pm 4,9^{\# \#}$ \\
\hline
\end{tabular}

$* * \mathrm{p}<0,01$ vs Controle ${ }^{\#} \mathrm{p}<0,01$ vs FP 

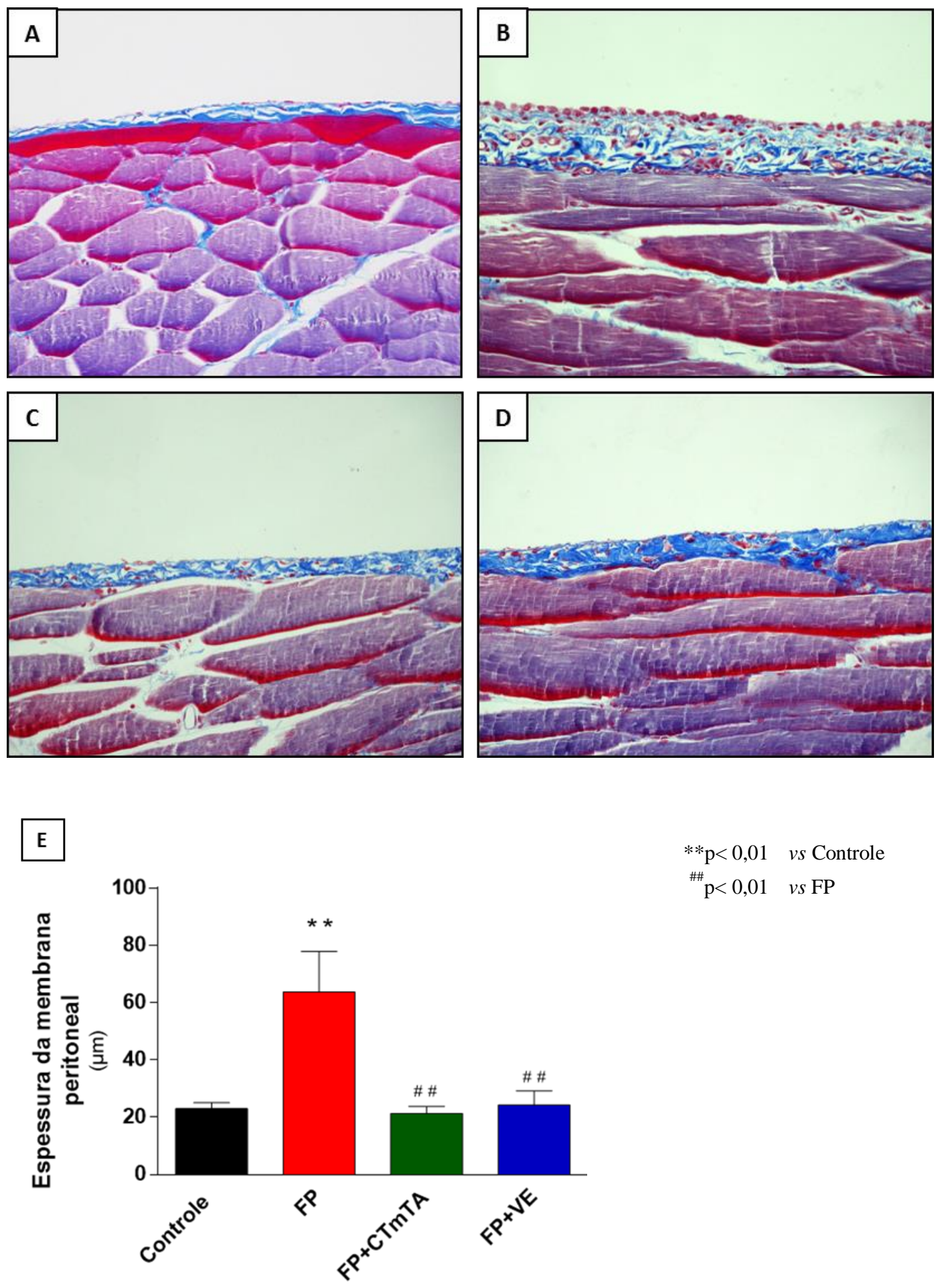

Figura 10. Fotomicrografias representativas de amostras de MP corados com Tricrômio de Masson (400x). A) grupo Controle demonstrando uma fina camada submesotelial; B) grupo FP demonstrando um espessamento da camada submesotelial; C) grupo FP+CTmTA e D) grupo $\mathrm{FP}+\mathrm{VE}$ demonstram que o espessamento da camada submesotelial foram menores que o do grupo FP. E) Análise da quantificação da espessura da membrana peritoneal $(\mathrm{p}<0,01)$ 


\subsubsection{Fibronectina}

A expressão gênica relativa da fibronectina, analisada por PCR de tempo real, foi significativamente maior no grupo FP, quando comparada com o grupo Controle. Os tratamentos com CTmTA e VE bloquearam, de maneira significativa, o aumento da expressão da fibronectina (Tabela 7 e Figura 11).

Tabela 7. Expressão gênica da fibronectina na MP

\begin{tabular}{lc}
\hline Controle & $\begin{array}{c}\text { Fibronectina } \\
\text { (expressão relativa) }\end{array}$ \\
\hline $\boldsymbol{F P}$ & $1,00 \pm 0,86$ \\
$\boldsymbol{C T} \boldsymbol{T} \boldsymbol{T A}$ & $12,81 \pm 0,95^{* * *}$ \\
$\boldsymbol{V E}$ & $0,36 \pm 1,12^{\# \#}$ \\
\hline
\end{tabular}

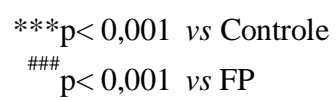

Fibronectina

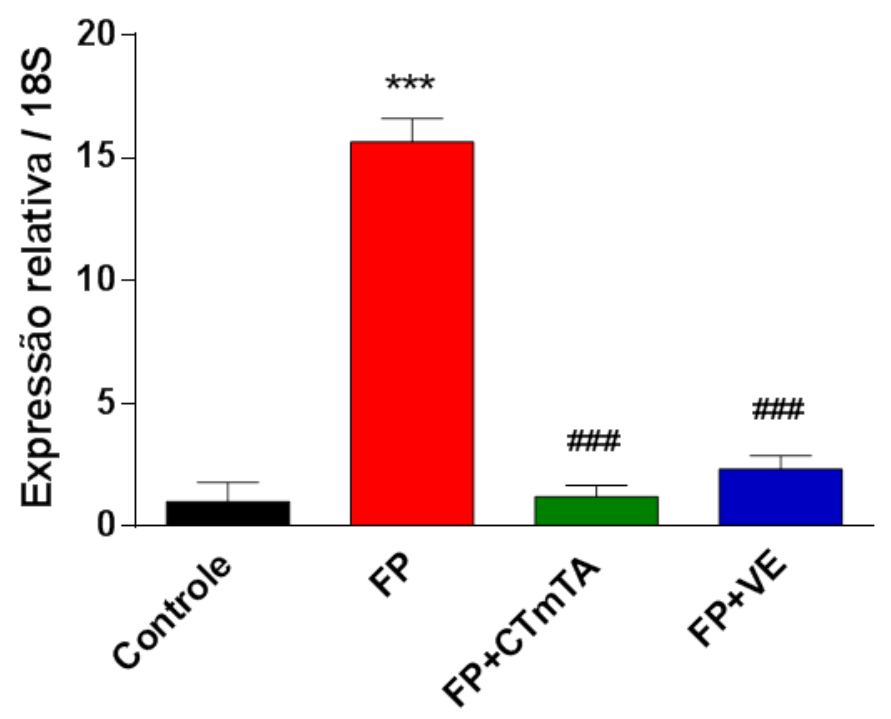

Figura 11. Expressão gênica da Fibronectina na MP dos grupos estudados 


\subsubsection{Miofibroblastos}

Os miofibroblastos foram quantificados como a porcentagem da área da MP marcada, por imunohistoquímica, para $\alpha$-SMA. No grupo FP houve um aumento significativo da área marcada, com relação ao grupo Controle. Nos grupos tratados com CTmTA e VE houve redução significativa da área marcada para $\alpha$-SMA quando comparado ao grupo FP (Tabela 8 e Figura 12).

Tabela 8. Quantificação da área marcada para $\alpha$-SMA no dia 30

\begin{tabular}{lc}
\hline & $\begin{array}{c}\boldsymbol{\alpha} \text {-SMA } \\
(\% \text { da área })\end{array}$ \\
\hline Controle & $0,09 \pm 0,13$ \\
$\boldsymbol{F P}$ & $1,69 \pm 0,60 *$ \\
$\boldsymbol{C T m T A}$ & $0,22 \pm 0,19^{\# \#}$ \\
$\boldsymbol{V E}$ & $0,20 \pm 0,06^{\#}$ \\
\hline
\end{tabular}

$\begin{aligned}{ }_{\mathrm{p}} \mathrm{p}<0,05 & \text { vs Controle } \\ \# \mathrm{p}<0,05 & \text { vs FP } \\ \# \# \text { p }<0,01 & \text { vs FP }\end{aligned}$



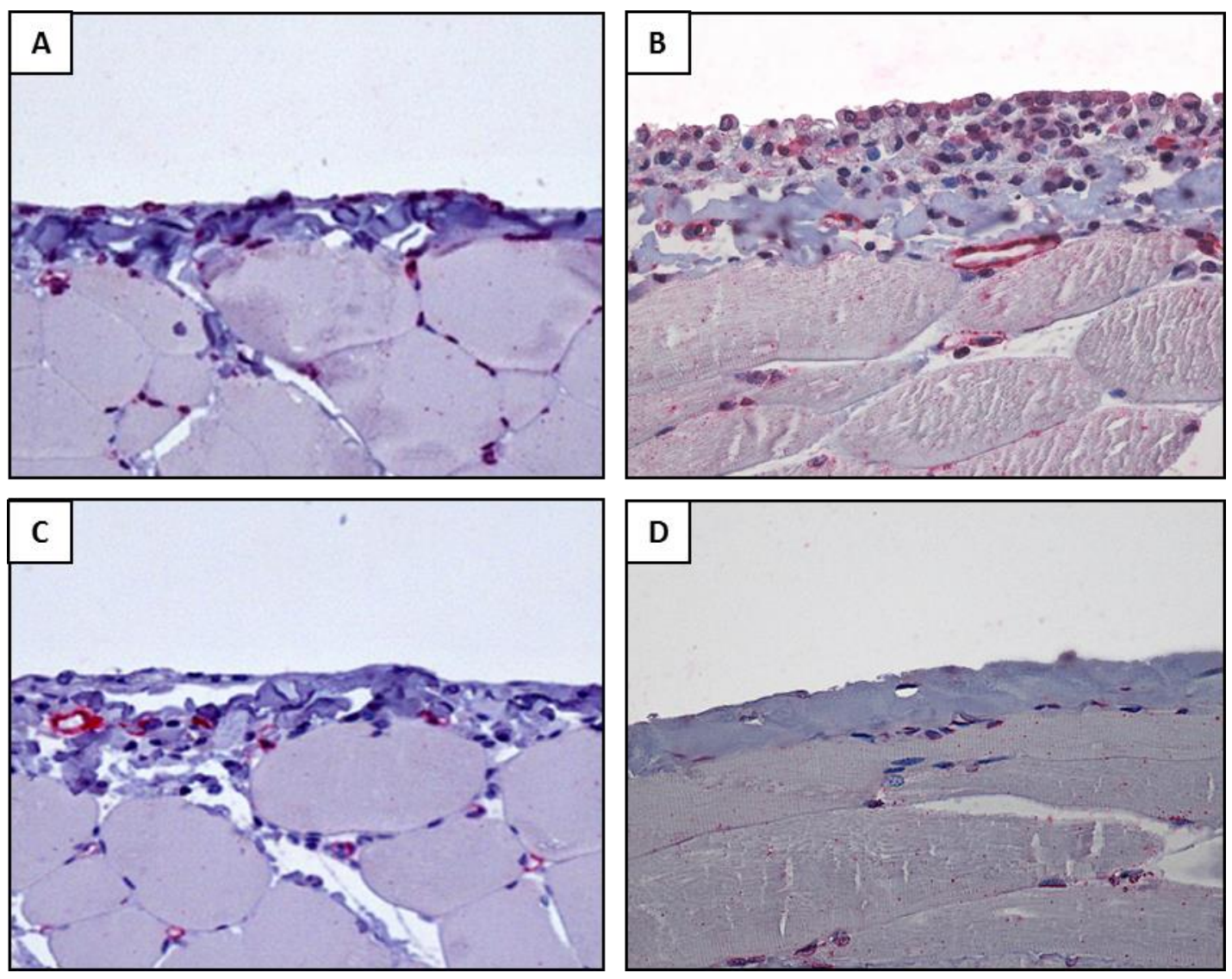

$\mathrm{E}$
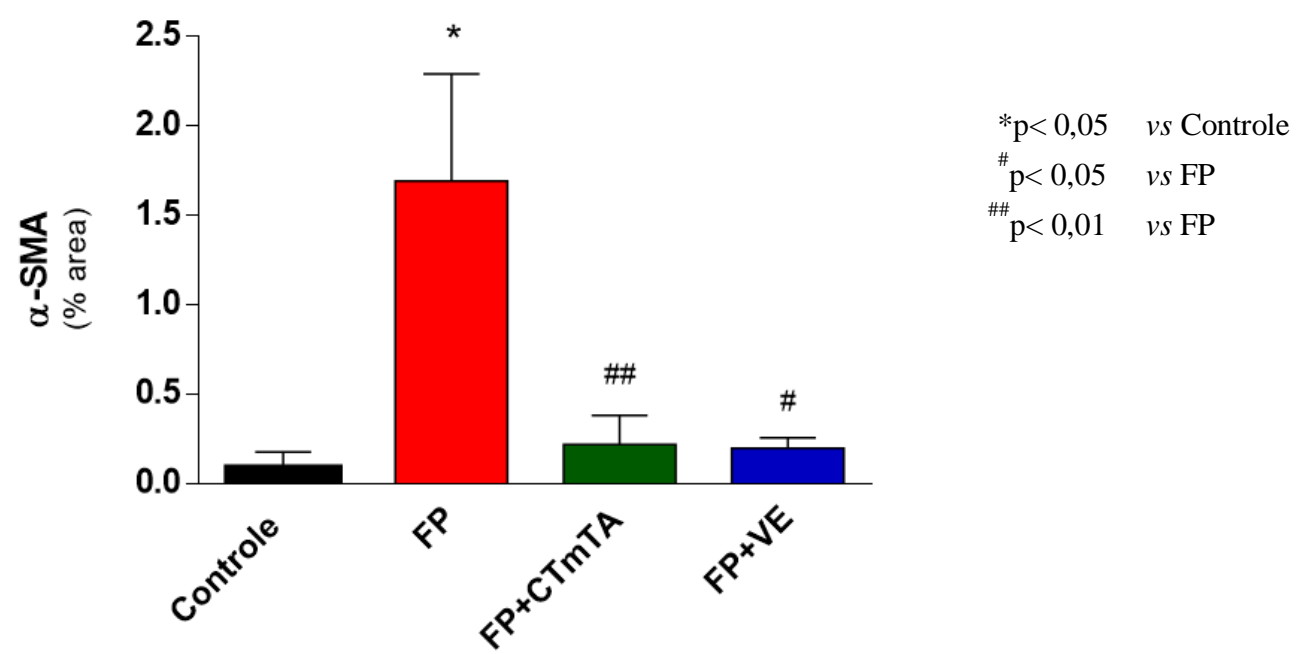

Figura12. Fotomicrografias representativas da imunohistoquímica para $\alpha$-SMA na MP (400x). (A) ratos do grupo Controle apresentando poucas células positivas; (B) ratos do grupo FP com um acúmulo de miofibroblastos (coloração em vermelho na membrana peritoneal); (C) redução da expressão de $\alpha$-SMA nos grupos tratados com CTmTA (D) e com VE; (E) Quantificação da $\alpha$-SMA (\% da área) em todos os grupos estudados 


\subsubsection{TGF- $\beta$ e FSP-1}

As expressões gênicas do TGF- $\beta$, o principal gene envolvido no processo fibrótico do peritôneo, e do FSP-1, um fator pró-fibrótico dependente do TGF- $\beta$, foram analisadas pela técnica de PCR em tempo real. No grupo FP houve um aumento significativo do TGF- $\beta$ e do FSP-1 quando comparados ao grupo controle. Os tratamentos com CTmTA e VE reduziram a expressão desses genes, quando comparados ao grupo FP, com níveis de expressão próximos ao do grupo Controle (Tabela 9 e Figura 13).

Tabela 9. Expressão gênica de TGF- $\beta$ e FSP-1 na MP

\begin{tabular}{|c|c|c|c|}
\hline & $\begin{array}{c}\text { TGF- } \boldsymbol{\beta} \\
\text { (expressão relativa) }\end{array}$ & $\begin{array}{c}\text { FSP-1 } \\
\text { (expressão relativa) }\end{array}$ & \\
\hline Controle & $1,00 \pm 1,00$ & $1,00 \pm 0,65$ & $\begin{array}{l}* * * \mathrm{p}<<0,001 \text { vs Controle } \\
\# \# \# \text { p }<0,001 \text { vs FP }\end{array}$ \\
\hline$F P$ & $13,90 \pm 1,03 * * *$ & $18,45 \pm 1,02^{* * *}$ & \\
\hline$F P+C T m T A$ & $0,82 \pm 1,27^{\# \# \#}$ & $1,34 \pm 0,45^{\# \# \#}$ & \\
\hline$F P+V E$ & $0,64 \pm 0,98^{\# \# \#}$ & $1,32 \pm 0,34^{\# \# \#}$ & \\
\hline
\end{tabular}




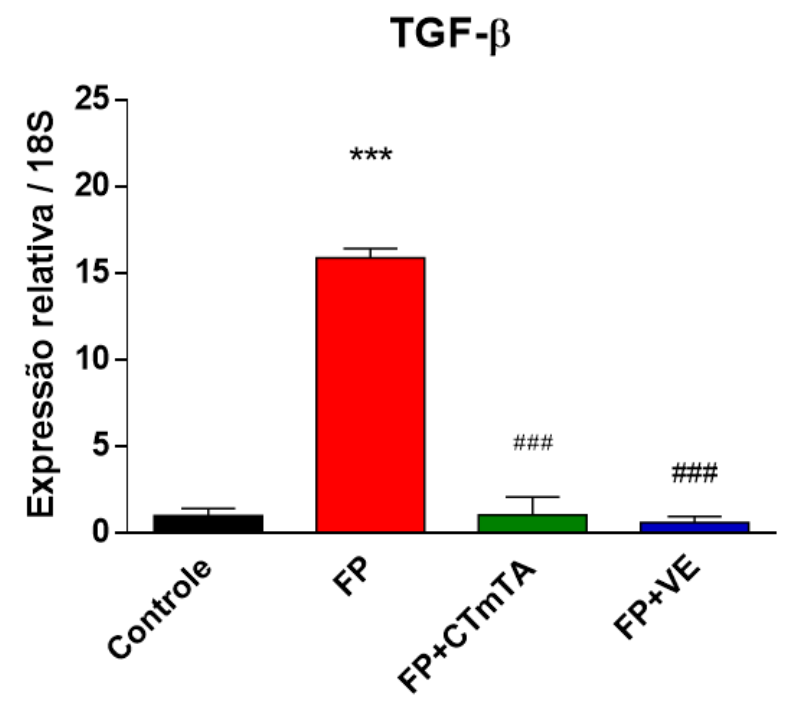

$* * * \mathrm{p}<0,001$ vs Controle

\#\#\# $\mathrm{p}<0,001$ vs FP

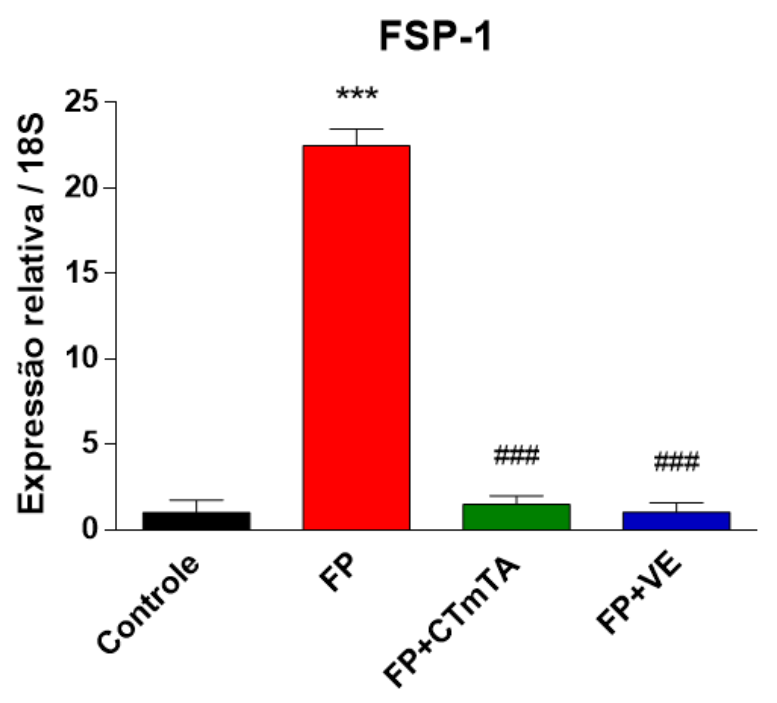

Figura 13. Expressão gênica do TGF- $\beta$ e do FSP-1 na MP em todos os grupos estudados 


\subsubsection{Via TGF/Smad: expressão de $\operatorname{Smad} 3$ e Smad 7}

As Smad3 e Smad7 são mediadores intracelulares críticos envolvidos na sinalização de TGF- $\beta$. A fosforilação intracelular da Smad3 conduz à transcrição de genes pró-fibróticos e a expressão da Smad7 bloqueia a sinalização de TGF $\beta /$ Smad.

Neste estudo, a expressão da Smad3 foi significativamente maior na MP do grupo FP, em comparação à do grupo Controle. Os tratamentos com CTmTA e VE reduziram a expressão gênica desse marcador na membrana peritoneal.

Animais tratados com CTmTA e VE tiveram a expressão aumentada da Smad7 na MP comparada ao grupo FP. No grupo tratado com VE houve aumento significativo quando comparado ao grupo tratado com CTmTA (Tabela 10 e Figura 14).

Tabela 10. Expressão gênica de $\operatorname{Smad} 3$ e $\operatorname{Smad} 7$

\begin{tabular}{lcc}
\hline & $\begin{array}{c}\text { Smad3 } \\
\text { (expressão relativa) }\end{array}$ & $\begin{array}{c}\text { Smad7 } \\
\text { (expressão relativa) }\end{array}$ \\
\hline Controle & $1,00 \pm 0,80$ & $1,00 \pm 0,90$ \\
$\boldsymbol{F P}$ & $5,34 \pm 0,57 *$ & $102,70 \pm 2,01^{* * *}$ \\
$\boldsymbol{F P + C T \boldsymbol { T T A }}$ & $2,82 \pm 1,36$ & $321,24 \pm 2,26^{\# \# \#}$ \\
$\boldsymbol{F P +} \boldsymbol{V E}$ & $3,39 \pm 0,96$ & $786,88 \pm 1,05^{\# \# \S \S \S}$ \\
\hline
\end{tabular}




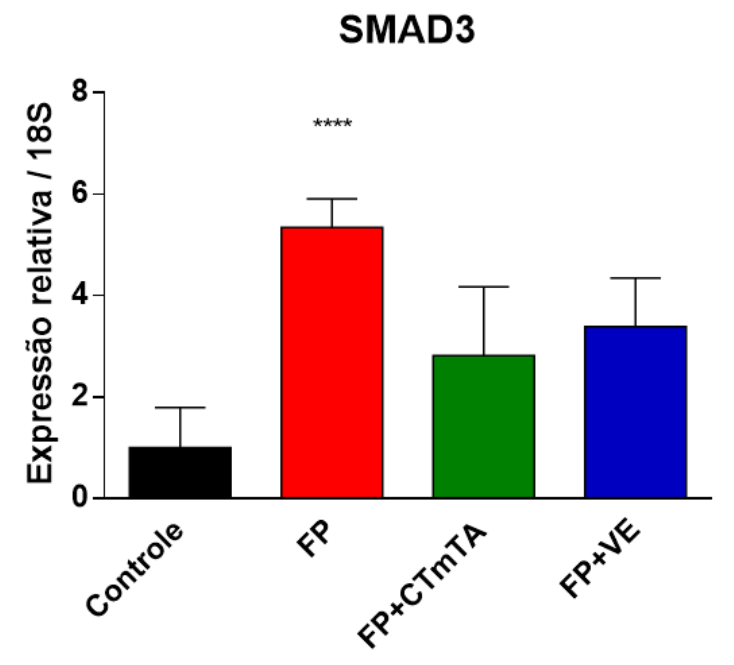

$* \mathrm{p}<0,05$ vs Controle $* * * p<0,001$ vs Controle \#\#\# $\mathrm{p}<0,001$ vs FP

$\$ s \S \mathrm{p}<0,001$ vs CTmTA

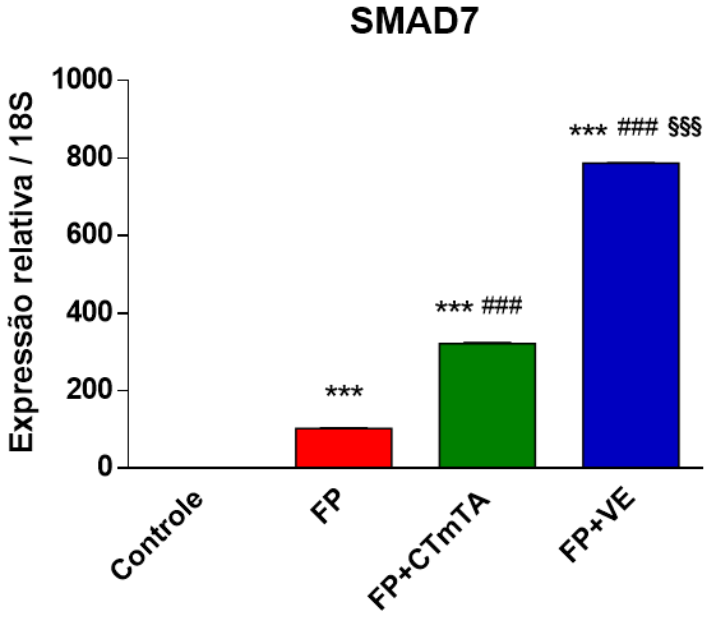

Figura14. Expressão gênica de Smad3 e Smad7 na MP 


\subsubsection{Perfil inflamatório}

Para análise do efeito das CTmTA e das VE na inflamação da MP foram analisados por imunohistoquímica os infiltrados de macrófagos (CD68) e de linfócitos (CD43) e por PCR em tempo real a expressão relativa de TNF- $\alpha$, uma citocina próinflamatória.

5.3.7.a) Macrófagos e linfócitos: Os animais do grupo FP apresentaram um aumento significativo do número de macrófagos, quando comparado ao grupo controle. Os tratamentos com CTmTA e VE, preveniram a infiltração macrofágica na MP. De forma semelhante, houve um aumento na infiltração dos linfócitos no grupo FP e diminuição significativa nos grupos tratados (Tabela 11 e Figuras 15 e 16).

Tabela 11. Quantificação dos macrófagos e linfócitos na MP

\begin{tabular}{lcc}
\hline & $\begin{array}{r}\text { CD68 (ED1+) } \\
(\text { células/mm²) }\end{array}$ & $\begin{array}{c}\text { CD43 } \\
\left(\text { células } / \mathrm{mm}^{2}\right)\end{array}$ \\
\hline Controle & $79 \pm 32$ & $3 \pm 1$ \\
$\boldsymbol{F P}$ & $404 \pm 122^{* * *}$ & $87 \pm 31 *$ \\
$\boldsymbol{F P}+\boldsymbol{C T} \boldsymbol{T} \boldsymbol{T A}$ & $263 \pm 62^{\# \# \#}$ & $8 \pm 3^{\#}$ \\
$\boldsymbol{F P}+\boldsymbol{V E}$ & $148 \pm 16^{\# \# \#}$ & $11 \pm 4^{\# \#}$ \\
\hline
\end{tabular}

$* \mathrm{p}<0,05$ vs Controle
$* * * \mathrm{p}<0,001$ vs Control
${ }_{\#} \mathrm{p}<0,05 \quad$ vs FP
${ }_{\# \#} \mathrm{p}<0,01 \quad$ vs FP
${ }_{\# \# \#} \mathrm{p}<0,001$ vs FP



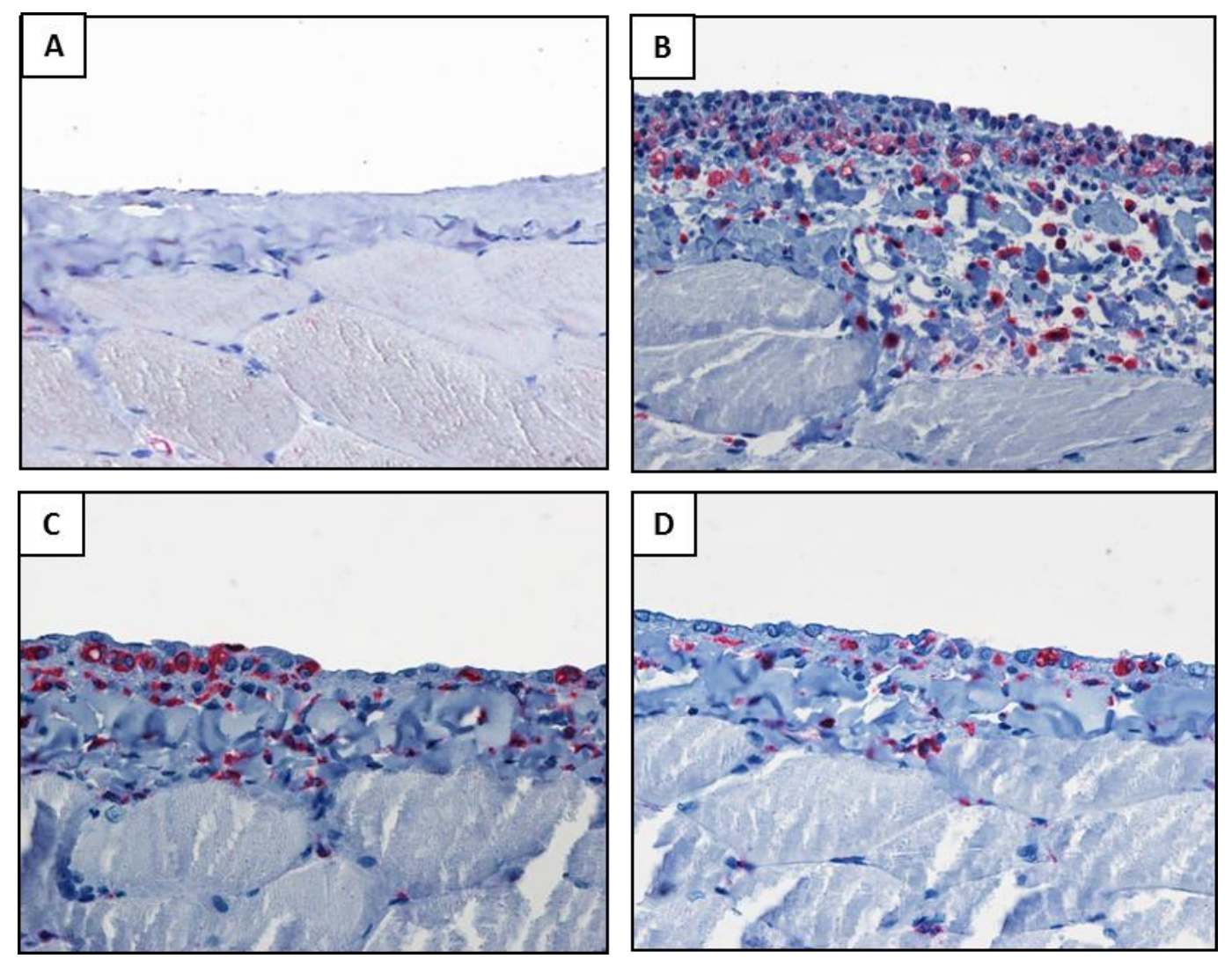

$\mathrm{E}$

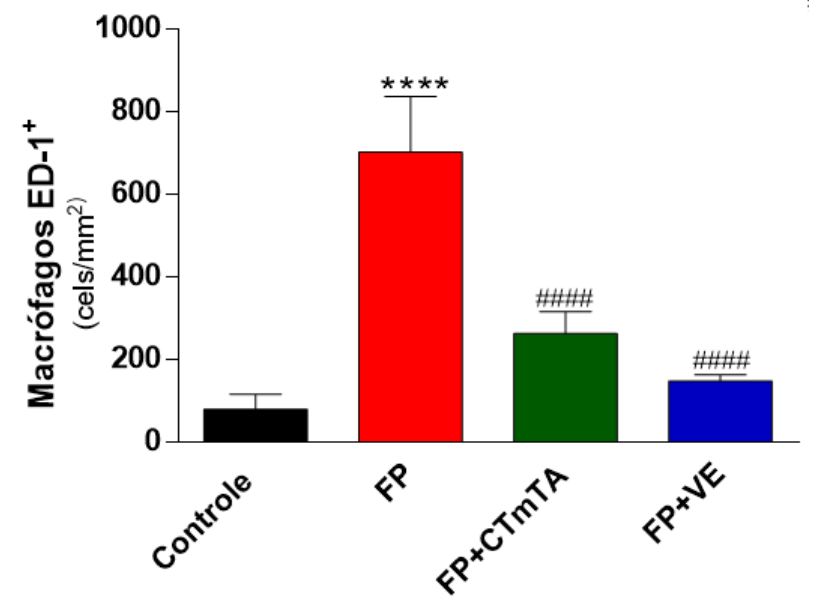

Figura 15. Fotomicrografias representativas da imunohistoquímica para macrófagos (ED1). (400x). (A) grupo Controle, com poucas células positivas; (B) grupo FP, com presença acentuada de macrófagos (vermelho) na membrana peritoneal; (C) e (D) grupos tratados com CTmTA e com VE, respectivamente; com redução do número de macrófagos; (E) Quantificação do número de macrófagos na membrana peritoneal em todos os grupos 

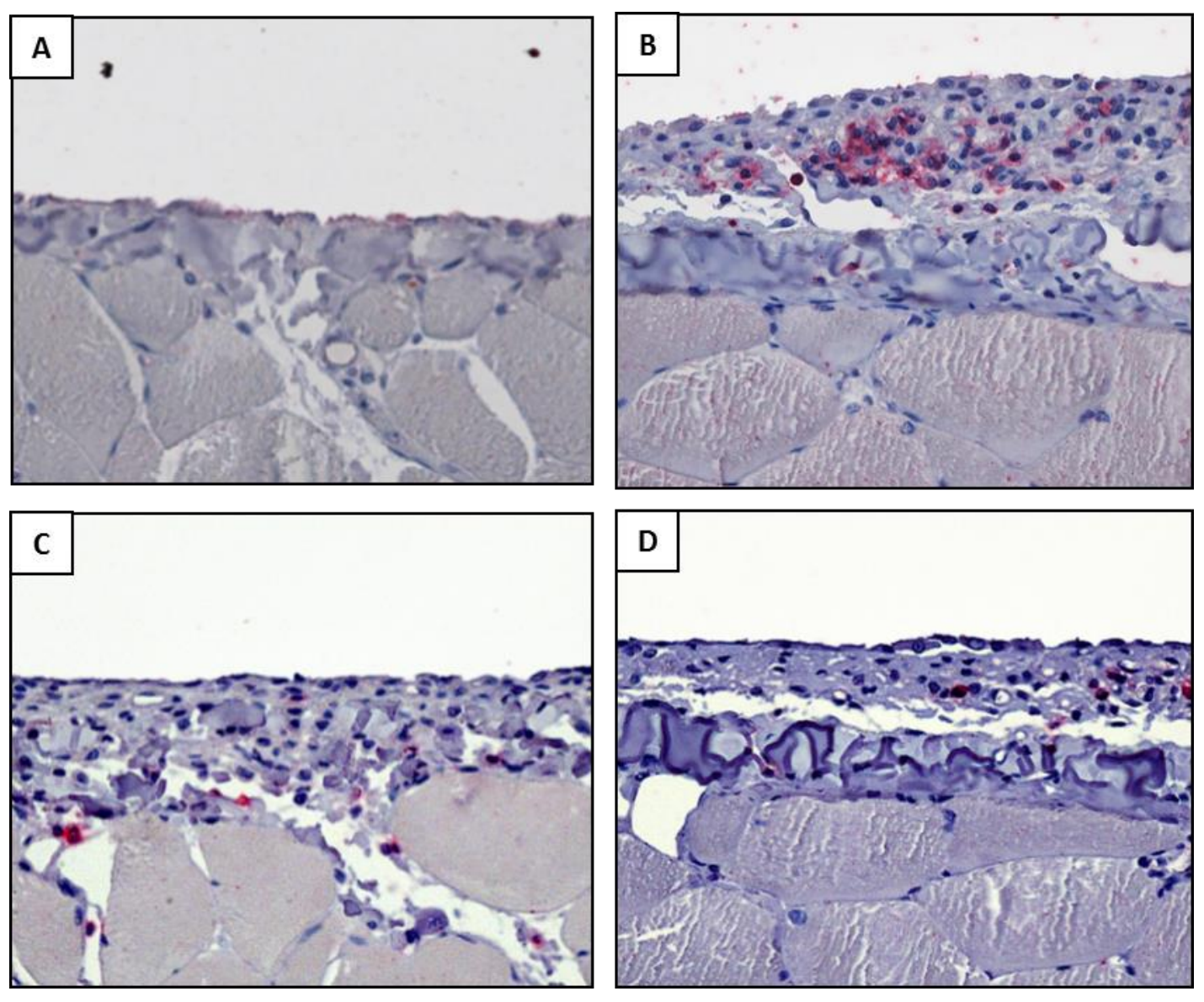

$\mathrm{E}$

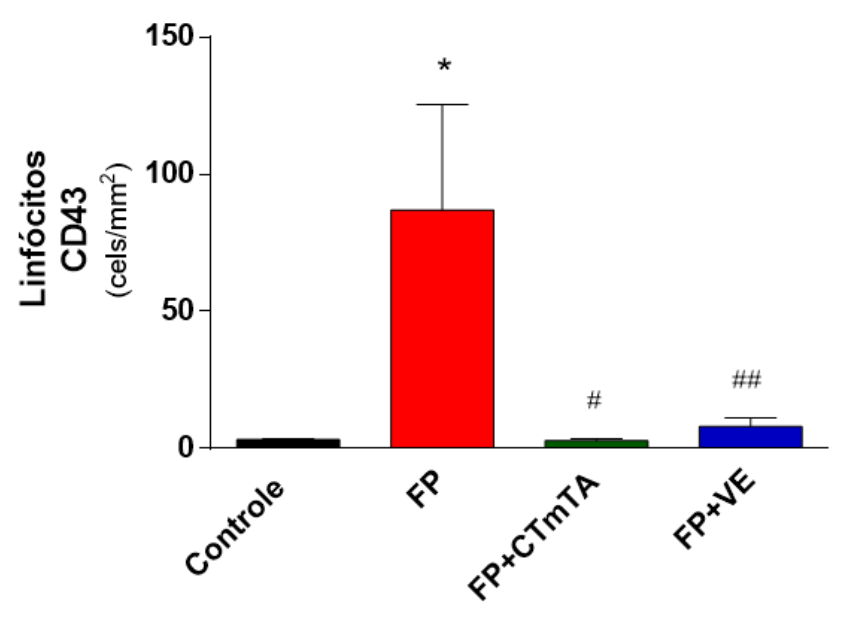

$\begin{array}{ll}{ }^{*} \mathrm{p}<0,05 & \text { vs Controle } \\ { }^{\#} \mathrm{p}<0,05 & \text { vs FP } \\ { }^{\# \#}{ }_{\mathrm{p}<0,01} & \text { vs } \mathrm{CTmTA}\end{array}$

Figura 16. Fotomicrografias representativas da imunohistoquímica para linfócitos (CD43) (400x). (A) grupo Controle, com poucas células positivas (B) grupo FP, com presença acentuada de linfócitos (vermelho) na membrana peritoneal; (C) e (D) grupos tratados com CTmTA e com VE, respectivamente; com redução do número de linfócitos; (E) Quantificação do número de linfócitos na membrana peritoneal em todos os grupos 
5.3.7.b) Expressão do TNF-a: No grupo FP houve um aumento significativo da expressão gênica da citocina pró-inflamatórias TNF- $\alpha$ quando comparado ao grupo controle. Os tratamentos com CTmTA e VE reduziram de forma significativa a expressão gênica do TNF- $\alpha$, quando comparados ao grupo FP (Tabela 12 e Figura 17).

Tabela12. Expressão gênica da citocina pró-inflamatória TNF- $\alpha$ na MP

\begin{tabular}{lc}
\hline & $\begin{array}{c}\text { TNF- } \boldsymbol{\alpha} \\
\text { (expressão relativa) }\end{array}$ \\
\hline Controle & $1,00 \pm 0,62$ \\
$\boldsymbol{F P}$ & $9,06 \pm 0,95^{* * * *}$ \\
$\boldsymbol{F P}+\boldsymbol{C T m T A}$ & $1,06 \pm 0,66^{\# \#}$ \\
$\boldsymbol{F P + V E}$ & $0,98 \pm 0,65^{\# \#}$ \\
\hline
\end{tabular}

$\begin{array}{ll}* * * \mathrm{p}<0,001 & \text { vs Controle } \\ \# \# \# \mathrm{p}<0,001 & \text { vs FP }\end{array}$

TNF- $\alpha$

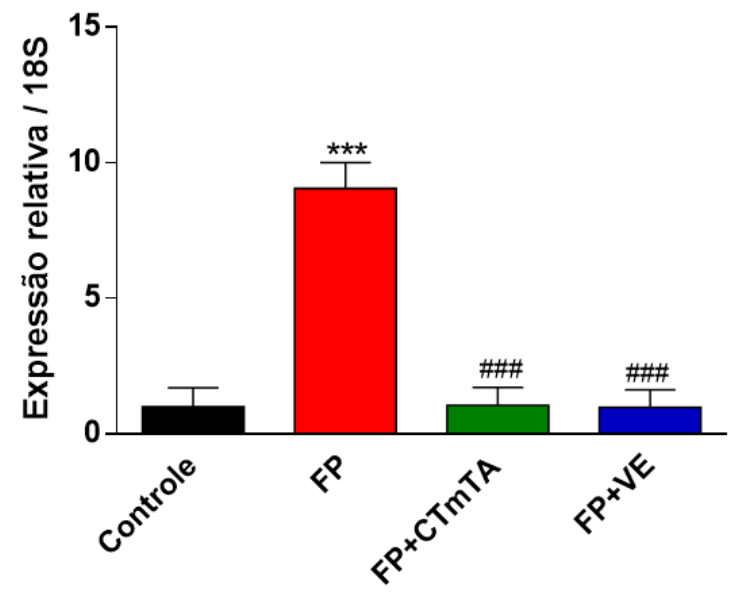

Figura 17. Expressão do gene pró-inflamatório TNF- $\alpha$ na MP 


\subsubsection{Funcão Peritoneal}

A função peritoneal foi significativamente afetada no grupo FP, uma vez que os valores do volume filtrado e a relação da glicose $\mathrm{D}_{2} / \mathrm{D}_{0}$ foram menores comparados aos dos animais do grupo Controle. No grupo que recebeu CTmTA, não foi verificada melhora na UF, comparado à do grupo FP. Porém, no grupo FP que recebeu VE, houve aumento significativo da UF com relação ao grupo FP. Os tratamentos com CTmTA e VE não interferiram no transporte de glicose, $\mathrm{D}_{2} / \mathrm{D}_{0}$, comparado ao grupo FP (Tabela 13, Figura 18).

Tabela 13. Função Peritoneal em todos os grupos no dia 30

\begin{tabular}{lcc}
\hline & $\begin{array}{c}\text { Ultrafiltração } \\
(\mathrm{mL})\end{array}$ & $\begin{array}{c}\text { Glicose } \\
\mathrm{D}_{2} / \mathrm{D}_{0}\end{array}$ \\
\hline Controle & $12,6 \pm 0,9$ & $0,16 \pm 0,004$ \\
$\boldsymbol{F P}$ & $2,8 \pm 1,1^{* * *}$ & $0,11 \pm 0,011^{*}$ \\
$\boldsymbol{C T m} \boldsymbol{T A}$ & $4,6 \pm 1,1^{* * *}$ & $0,09 \pm 0,012^{* *}$ \\
$\boldsymbol{V E}$ & $6,3 \pm 1,2 * * * \#$ & $0,11 \pm 0,016^{* *}$ \\
\hline
\end{tabular}

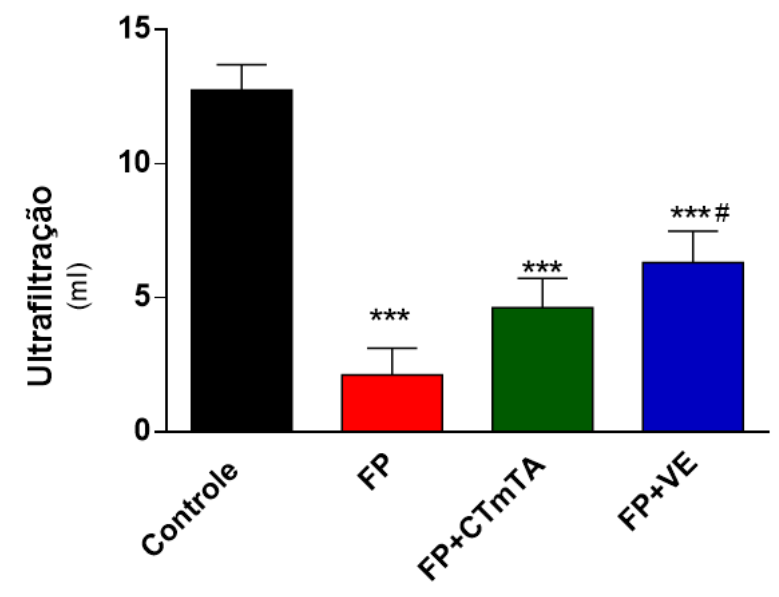

$* \mathrm{p}<0,05$ vs Controle $* * \mathrm{p}<0,01$ vs Controle $* * * \mathrm{p}<0,001$ vs Controle ${ }^{\#} \mathrm{p}<0,05$ vs FP

Figura 18. Ultrafiltração na MP dos grupos estudados, no dia 30 


\subsubsection{Neoangiogênese}

5.3.9.a) Densidade Capilar: No grupo FP foi observado um aumento da densidade capilar da MP, marcado com isolectina-B4 em relação ao grupo controle. Os tratamentos com CTmTA e VE mantiveram a densidade capilar semelhante ao grupo FP (Tabela 14, Figura 19).

Tabela 14. Quantificação da densidade capilar (Isolectina-B4) no dia 30

\begin{tabular}{lc}
\hline Controle & $\begin{array}{c}\text { Isolectina-B4 } \\
\left(\text { vasos } / \mathrm{mm}^{2}\right)\end{array}$ \\
$\boldsymbol{F P}$ & $1,16 \pm 1,00$ \\
$\boldsymbol{F P}+\boldsymbol{C T m T A}$ & $2,60 \pm 1,40$ \\
$\boldsymbol{F P}+\boldsymbol{V E}$ & $2,27 \pm 1,00$ \\
\hline
\end{tabular}



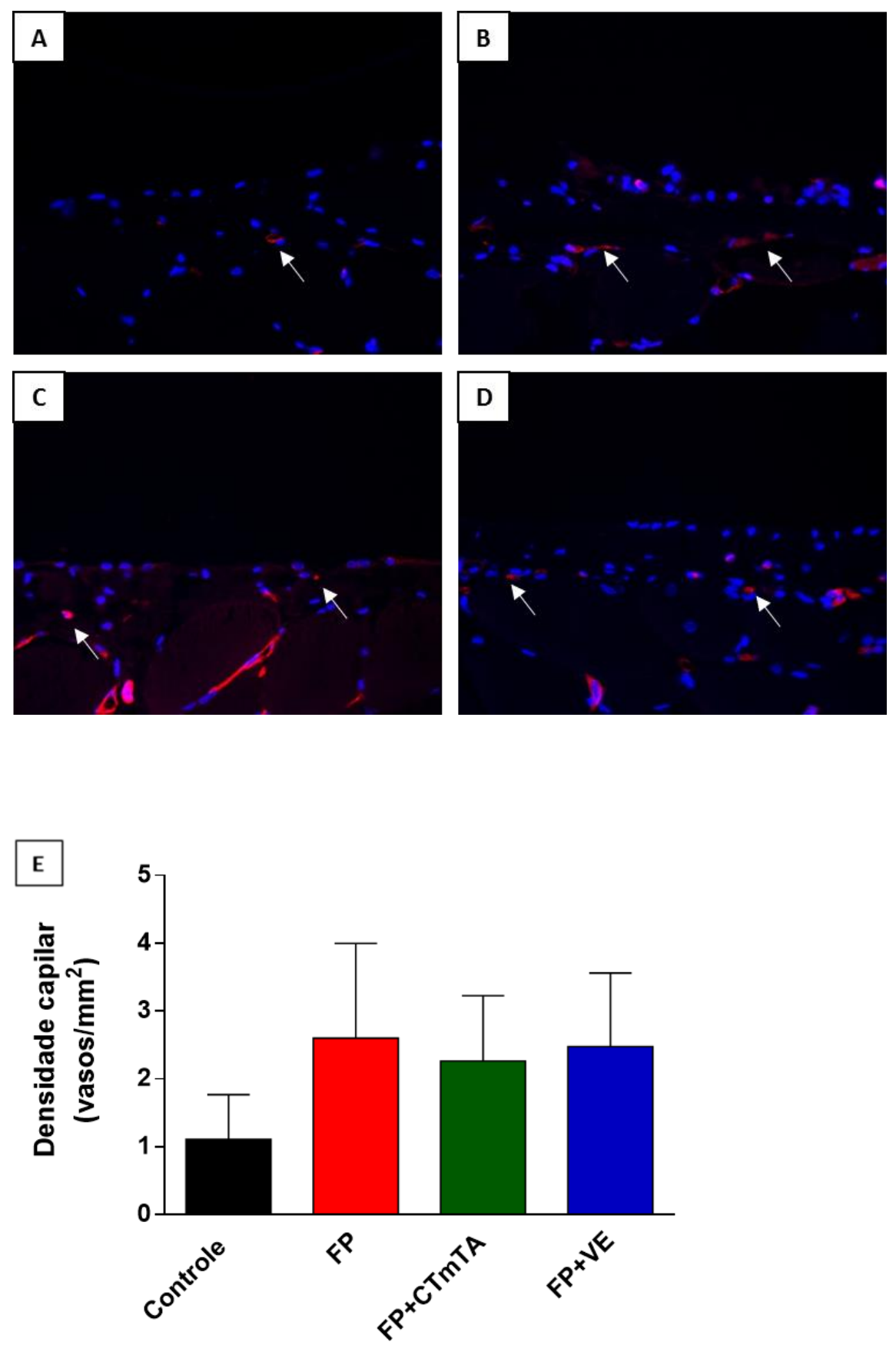

Figura19. Densidade capilar na MP. Fotomicrografias representativas da imunofluorescência para Isolectina-B4, um marcador de endotélio (corada em vermelho) e DAPI ${ }^{+}$, um marcador nuclear (corada em azul) na membrana peritoneal (400x). (A) grupo controle apresentando poucas células positivas; (B) grupo FP com pequeno aumento no número de vasos. Os tratamentos mantiveram a neoformação vascular (C) grupo CTmTA (D) grupo VE. (E) Quantificação da densidade capilar na membrana peritoneal. Dados apresentados como média \pm erro padrão 
5.3.9.b) Expressão do VEGF: A expressão gênica do VEGF foi aumentada no grupo FP, enquanto os tratamentos com CTmTA e VE diminuíram significativamente a expressão gênica do VEGF comparado ao grupo FP (Tabela 15, Figura 20).

Tabela 15. Expressão gênica do VEGF na MP

\begin{tabular}{|c|c|c|}
\hline & $\begin{array}{c}\text { VEGF } \\
\text { (expressão relativa) } \\
\end{array}$ & $\begin{array}{cc}* \mathrm{p}<0,05 & \text { vs Controle } \\
* * * \mathrm{p}<0,001 & \text { vs Controle } \\
* \# \# \mathrm{p}<0,001 & \text { vs FP }\end{array}$ \\
\hline Controle & $1,00 \pm 0,62$ & \\
\hline$F P$ & $46,72 \pm 1,62 * * *$ & \\
\hline$F P+C T m T A$ & $7,82 \pm 1,17 * \# \#$ & \\
\hline$F P+V E$ & $4,44 \pm 0,68 \# \# \#$ & \\
\hline
\end{tabular}

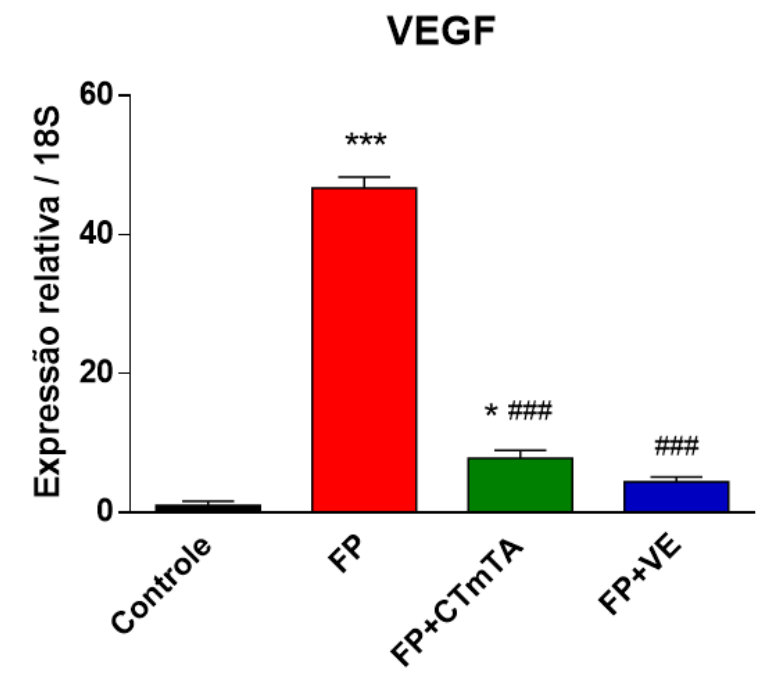

Figura 20. Níveis da expressão gênica do VEGF na MP. 


\section{DISCUSSÃO}

A eficácia da DP depende da integridade estrutural e funcional do peritôneo. Essa integridade é perdida de forma progressiva ao longo dos anos de terapia devido a alterações morfológicas, que ocorrem por perda da camada mesotelial, inflamação, neoangiogênese e FP. Além de alterações funcionais, que se expressam clinicamente por aumento do transporte de solutos e por falha na capacidade de UF (Devuyst et al., 2010).

Essa situação, encontrada nos pacientes que fazem a terapia renal substitutiva por DP, pode ser reproduzida através de modelos experimentais capazes de induzir FP em um curto período de tempo. O modelo que está padronizado em nosso laboratório é baseado na irritação química e peritonite asséptica (Suga et al., 1995) e resulta em um elevado espessamento do peritôneo, aumento da proliferação celular, infiltrado inflamatório e acúmulo da matriz extracelular na camada submesotelial do peritôneo.

A perda a integridade do peritôneo nos pacientes submetidos à DP tem tratamento limitado, levando na maioria dos casos à conversão para hemodiálise. Estratégias que previnam ou bloqueiem a progressão das complicações causadas pela DP são de grande relevância. Em pacientes, o tratamento com corticoides é o tratamento mais utilizado, mas possuem efeitos adversos graves. Mais recentemente, o tamoxifeno foi utilizado com sucesso no tratamento de casos de peritonite esclerosante encapsulante e na regressão da fibrose retroperitoneal idiopática (Clarck et al., 1991; Allaria et al., 1999; Guest et al 2009). O desenvolvimento de novas terapias anti-fibróticas pode trazer grandes benefícios na qualidade de vida dos pacientes dialíticos, atenuando a progressão da fibrose e os subsequentes danos ao longo do tratamento (Yu et al., 2014). 
As CTm apresentam um grande potencial terapêutico em doenças associadas à fibrose, motivo pelo qual foram escolhidas como forma de tratamento preventivo para FP. Várias evidências indicam que essas células modulam o microambiente da lesão, favorecendo a regeneração tecidual. O mecanismo de ação dessas células está associado, principalmente, à liberação de uma variedade de fatores e VE (Baraniak et al., 2010; Heldring et al., 2015; Börger et al., 2017).

O objetivo central do presente estudo foi comparar o possível efeito terapêutico da administração da CTmTA ou de VE derivadas de CTmTA na prevenção da FP experimental em ratos. Para tanto, os protocolos de obtenção, detecção e quantificação das VE extraídas do meio de cultura das CTmTA na 4a passagem foram padronizados e estabelecidos.

O isolamento de CTmTA de ratos é um procedimento relativamente simples e de alto rendimento. No entanto, para ter aplicabilidade confiável, requer boas práticas de cultivo e caracterização, seguindo os critérios mínimos estabelecidos pela Sociedade Internacional de Terapia Celular (Dominici et al 2006). Deve-se ressaltar que tais critérios são estabelecidos para células humanas e que, na falta de padronização para CTm de ratos, optou-se por seguir as diretrizes para células humanas.

O cultivo das CTmTA foi realizado por um período de tempo de três a quatro semanas, até a confirmação do perfil da população celular isolada. Primeiramente, foi observado que as células possuíam capacidade de aderência à superfície plástica. Após algumas passagens, foram realizados experimentos para confirmar o perfil celular da população isolada. Como essas células não possuem um marcador específico para defini-las, foi realizada análise de um conjunto de marcadores. Neste estudo, as CTmTA expressaram intensamente CD29, CD44, CD90, CD105 e não apresentaram expressão para o marcador CD45. Além disso, foram feitos ensaios de diferenciação in vitro e as 
CTmTA apresentaram o potencial de se diferenciar em linhagens osteogênicas, adipogênicas e condrogênicas. Esses resultados, corroborados por outros estudos, confirmaram o perfil das CTm em ratos (Dominici et al 2006; Bayati et al 2013; Lotfy et al 2014).

A etapa principal, ao se trabalhar com VE, é o isolamento dessas partículas. Diversas metodologias de isolamento das VE vêm sendo publicadas, desde ultracentrifugação até métodos baseados em cromatografia (Théry et al., 2006; Raposo et al., 2013, Lötvall et al., 2014; Börger et al., 2017). No entanto, o método padrão ouro para o isolamento de VE é a ultracentrifugação. Para o êxito do processo de padronização, é importante obter uma população homogênea, com métodos consistentes de caracterização e quantificação das VE para posterior administração nos animais.

Estudos que isolam as VE por ultracentrifugação geralmente têm protocolos que consistem numa primeira etapa de rotação a baixa velocidade, para eliminação de células mortas do meio de cultura, seguida de rotação a alta velocidade, em 100.000×g, onde ocorre a precipitação das VE (Théry et al., 2006; Raposo et al., 2013; Zhou et al., 2013; Zhao et al., 2015; Sun et al., 2016). Seguindo este protocolo, nos primeiros testes de isolamento, logo após a ultracentrifugação, as VE foram caracterizadas por meio da quantificação das proteínas, microscopia eletrônica de transmissão (ME) e por rastreamento de nanopartículas (NTA). Como resultado, houve variações nas concentrações proteicas, foi encontrado material precipitado e morfologia heterogênea, e foram verificados diferentes tamanhos das VE. Portanto, para eliminar proteínas contaminantes e obter amostras de VE mais puras, foram introduzidas no protocolo etapas adicionais de lavagens do sedimento e de centrifugação a 100.000×g.

O isolamento das VE a partir do sobrenadante da cultura das CTm apresenta um fator inconveniente, que é a necessidade do uso de SFB durante o cultivo celular. O 
SFB possui vesículas que podem contaminar as VE liberadas pelas CTm cultivadas. Para evitar esse tipo de contaminação, dois métodos podem ser utilizados: a depleção das vesículas do SBF por ultracentrifugação antes da adição ao meio de cultura, e a eliminação do SFB do meio de cultura. O tempo de cultivo das células em meio sem SFB varia nos estudos, entre períodos de $24 \mathrm{~h}$ e 72h (Gatti et al., 2011; Zhou et al., 2013; Arslan et al., 2013; Wang et al., 2015; Nong et al., 2016;). Deve-se ressaltar que, qualquer que seja o método utilizado, a ausência de VE no soro deve ser comprovada. No caso da depleção, para descartar a possibilidade de contaminação, o SFB deve ser analisado pelos métodos de detecção por ME e quantificação por NTA. No caso do meio não suplementado com SFB, é importante analisar a viabilidade e a ocorrência de apoptose nas CTm (Phinney et al., 2015).

No presente trabalho, optou-se pela eliminação do SFB no meio de cultivo das CTmTA, por um período de 24 horas, baseado no trabalho de Gatti e colaboradores (Gatti et al., 2011). Para tanto, antes do isolamento, foi analisado a viabilidade e a apoptose das CTmTA cultivadas sem SFB e obteve-se 97\% de células viáveis e $4 \%$ de células apoptóticas. Mesmo assim, após o isolamento das VE foi detectada influência do SFB, determinada heterogeneidade nas amostras nas análises de ME e NTA. Na dúvida entre ter duas populações de tamanhos diferentes, ou contaminação por SFB, foram acrescentadas no protocolo mais etapas de lavagens, baseadas no trabalho de Théry (Théry et al., 2006).

O segundo desafio foi padronizar os métodos de caracterização das VE, que podem ser divididos em dois principais tipos: detecção e quantificação. Quando tomados em conjunto, permitem descartar possíveis contaminantes, como as vesículas oriundas do SFB e a presença de corpos apoptóticos, decorrentes da falta de normalização do processo de isolamento das VE. 
Um método importante para a quantificação das VE é a determinação da concentração proteica total do material recuperado ao final do processo de ultracentrifugação. Utilizando o reagente Pierce660nm, uma modificação do método de Bradford (Bradford et al., 1974), que minimiza o efeito da presença de lipídio na amostra, obteve-se resultados consistentes e reprodutíveis. Após alguns testes, foi determinado que a partir de $20,0 \mathrm{~mL}$ de meio de cultura de $2 \times 10^{6}$ células, são recuperadas $30 \mu \mathrm{g} / \mathrm{mL}$ de proteína.

A quantidade de proteína total recuperada, entretanto, não permite inferir sobre a qualidade das VE na amostra, uma vez que membranas de vesículas que porventura tenham se rompido durante a centrifugação podem estar presentes no pellet final, e suas proteínas associadas serão contabilizadas no pool dosado. Para avaliar a qualidade, do material isolado é imprescindível associar esses resultados às análises de detecção das VE.

A detecção das VE é feita usualmente por ME, que permite confirmar a presença, o tamanho e a morfologia das partículas isoladas. Este método foi essencial para verificar se o grau de pureza desejado na amostra havia sido atingido. Durante as tentativas de padronização do isolamento das VE, apesar da quantidade de proteína recuperada ser considerável para cada teste, as populações encontradas eram heterogêneas quanto ao tamanho e à morfologia, o que pôde ser identificado na ME acompanhado até o estabelecimento metodológico. Após os procedimentos para padronização, a análise por ME demonstrou o isolamento de uma população de VE em uma faixa de 100-200 nm. Entretanto, o rendimento do processo de isolamento de VE é baixo para um teste que necessita de, pelo menos, $100 \mu \mathrm{g}$ por experimento, por triplicata. Além disso, as vesículas não podem ser recuperadas para os demais experimentos de caracterização, ou para posterior aplicação nos animais. 
Posteriormente, as análises de NTA foram incluídas no procedimento de caracterização, pois neste tipo de análise, além de determinar o tamanho e a distribuição populacional das partículas de uma amostra, com faixa de detecção de 10 a 2000 nm de diâmetro, permite recuperar as amostras após a análise. Durante o processo de padronização, a presença de partículas contaminantes no meio de cultura foi monitorada por NTA. Após alterações nos procedimentos de lavagem do pellet, foi minimizada a presença desta fração contaminante e foi obtida uma população de VE homogênea, com tamanho entre 100 e $200 \mathrm{~nm}$ a cada isolamento. Dessa forma, foram obtidas amostras homogêneas e o método de isolamento de VE foi considerado padronizado em nosso laboratório.

A análise por Western Blot possibilita a detecção de proteínas específica das VE. Essa análise está entre os critérios mínimos estabelecidos para a caracterização das VE (Lötvall et al., 2014). No entanto, este tipo de análise não foi realizada neste trabalho devido à falta de marcadores.

Uma observação importante é que nem todos os métodos citados são aplicados rotineiramente com êxito. Neste aspecto, deve-se considerar o que contribui para isso é o baixo rendimento das VE e a confusão que ainda existe em relação à nomenclatura e à metodologia. A otimização e a padronização dos protocolos entre os grupos de estudo incluindo este - continuam sendo, assim, uma tarefa importante.

Para a terapia celular, a dose, o local, o momento de administração e a via de inoculação são aspectos que devem ser cuidadosamente considerados para melhores efeitos. No caso das CTm, a fonte de obtenção é outro importante fator, pois alguns tecidos são mais fáceis de coletar e possuem maior número de CTm quando comparados a outras fontes de obtenção. Neste contexto, o tecido adiposo possui um rendimento muito maior do que, por exemplo, o adquirido pela medula óssea (Bunnell et al., 2008). 
Neste estudo, foram inoculadas CTmTA e VE imediatamente após o isolamento e caracterização. Com o propósito de realizar análises comparativas, foram utilizadas doses equivalentes nos dois tratamentos. Portanto, no grupo tratado com CTmTA, foram usadas $2 \times 10^{6}$ de células, e no grupo tratado com VE foram usadas $30 \mu \mathrm{g}$ de VE, obtidas de $20 \mathrm{~mL}$ do meio de cultivo de $2 \times 10^{6}$ CTmTA. Além disso, os grupos tratados receberam, por via intraperitoneal, 2 doses de tratamento nos mesmos intervalos de tempo de administração ( $3^{\circ}$ e $10^{\circ}$ dias). Em estudo recente de nosso laboratório, Cavaglieri 2017, demonstrou que a administração subcapsular de uma dose de CTm de líquido amniótico, em modelo de doença renal crônica, foi efetiva no bloqueio da progressão da doença. Uma segunda dose de células contribuiu para reduzir os níveis de fibrose intersticial (Cavaglieri et al 2017).

Quanto ao uso terapêutico das VE, há uma variação de 10 a $200 \mu$ g na dose de VE injetado nos trabalhos publicados (He et al., 2012; Bruno et al.,2012; Zhou et al., 2013; Zou et al., 2014). Gatti e colaboradores realizaram em modelo de lesão renal aguda, no qual foi inoculado $30 \mu \mathrm{g}$ de VE derivadas de CTm por via endovenosa, imediatamente após a nefrectomia unilateral. Os autores descrevem que o tratamento com VE levou à inibição da apoptose, estímulo da proliferação de células epiteliais tubulares e evitou o comprometimento da função renal (Gatti et al., 2011). Seguindo este padrão de tratamento, no presente trabalho foi injetado $30 \mu \mathrm{g}$ de VE.

A via de inoculação escolhida para o presente trabalho foi a IP, ou seja, diretamente no local da lesão, como no estudo realizado por Baştuğ e colaboradores. Os autores compararam os efeitos da inoculação de CTmMO pelas vias endovenosa e IP, em modelo de DP. O tratamento com a administração IP apresentou melhores resultados quando comparado à via endovenosa, com aumento da capacidade de UF, além de diminuição mais significativas na expressão de TGF- $\beta$ e IL-6 (Baştuğ et al., 2014). 
O desenho do presente estudo foi cuidadosamente definido quanto ao intervalo entre a administração dos tratamentos, obedecendo sempre um período de $24 \mathrm{~h}$ após as injeções de GC. Um estudo relatou que a administração por injeções intraperitoneais de 0,1\% GC tem possivelmente efeito tóxico sobre CTmMO quando administradas 30 minutos antes do GC, pois apesar de ter ocorrido diminuição na expressão do TGF- $\beta$ os autores discutem que houve efeito parácrino e melhora em alguns parâmetros analisados, mas que devido a toxicidade causado pelo GC, as células permaneceram por um curto período de tempo no local injetado (Ueno et al., 2013).

O peritôneo sofre alterações histológicas e funcionais que estão diretamente relacionadas aos longos períodos de exposição a soluções de diálise e seus componentes não fisiológicos. Há um aumento da absorção de glicose e dissipação desse gradiente osmótico coincidente com uma diminuição da UF. Esses efeitos das soluções bioincompatíveis estão associados à inflamação e neoangiogênese. Em decorrência da neoangiogênese há um aumento no número de vasos na MP com consequente aumento na superfície de troca do peritôneo e aumento do transporte de glicose (De Lima et al., 2013; Morelle et al., 2015). A função da MP pode ser monitorada pelo transporte de glicose $\left(D_{t} \mid D_{0}\right)$, uma relação que é calculada dividindo-se a concentração de glicose do efluente peritoneal pela concentração de glicose na solução de DP infundida. Uma relação $D_{2} \backslash D_{0}$ baixa indica alta permeabilidade à glicose. No grupo com FP houve uma diminuição do transporte de glicose $\left(\mathrm{D}_{2} \backslash \mathrm{D}_{0}\right)$ quando comparado ao grupo controle. Os grupos tratados com CTmTA e VE mantiveram o transporte peritoneal de glicose semelhante aos resultados do grupo FP. Os tratamentos não alteraram o transporte de glicose pela MP em relação ao grupo FP, porém o grupo tratado com VE promoveu melhora na capacidade de UF. 
A perda da capacidade de UF pode ser decorrente de qualquer aumento no transporte de pequenos solutos através da membrana, que causa uma rápida dissipação do gradiente osmótico devido ao aumento da reabsorção de glicose (Devuyst et al., 2006). No Grupo FP houve uma diminuição na capacidade de UF. O grupo tratado com CTmTA não apresentou diferença na UF em relação ao Grupo FP, mas houve uma tendência de aumento. No grupo tratado com VE verificou-se um aumento do volume drenado pela MP, indicando melhora na capacidade de UF. Bastug e colaboradores realizaram um estudo em modelo de FP induzido por solução de diálise a 3,86\% e compararam o efeito da inoculação de CTmMO pelas vias endovenosa e IP. Os autores demonstraram um aumento da capacidade de UF no grupo que recebeu CTmMO via IP (Baştuğ et al., 2014).

As CTmTA e as VE preveniram a FP. A redução do espessamento da camada submesotelial nos animais que receberam CTmTA e VE foi semelhante aos resultados de um estudo realizado em modelo experimental de FP e tratado com CTm. Neste estudo, a solução de diálise contendo glicose a 3,86\% foi usada como indutor da FP, e o tratamento foi realizado com $1,5 \times 10^{6}$ de $\mathrm{CTmMO} / \mathrm{Kg}$, via IP ou endovenosa. Foi demonstrado redução da espessura da MP no grupo tratado com CTm quando comparado ao grupo com FP (Baştuğ et al., 2014). Em outro estudo em modelo de lesão renal aguda, realizado por Zou e colaboradores, o tratamento com 1 dose de $100 \mu \mathrm{g}$ de VE derivadas de células do cordão umbilical administradas via endovenosa foi capaz de reduzir a fibrose renal e reduzir apoptose (Zou et al., 2016).

Os tratamentos com CTmTA e VE bloquearam o aumento no número de miofibroblastos, a expressão de fibronectina e a expressão de fatores envolvidos na FP (TGF- $\beta$ e FSP-1) após indução por GC. O espessamento da MP se inicia com estímulos persistentes como infecção ou inflamação que ativam os miofibroblastos, um dos 
responsáveis pela fibrose na MP (Zhou et al., 2016). Usinier e colaboradores relatam que em modelo de fibrose o tratamento com CTm reduzem o número de células positivas para $\alpha$-SMA e diminuem fatores pró-fibróticos, como o TGF- $\beta$ (Usunier et al., 2014). Um estudo realizado em modelo de FP induzido por infusão de GC a $8 \%$ por 21 dias e tratados com $3 \times 10^{7}$ CTmTA via IP, demonstrou que as CTmTA foram capazes de diminuir a marcação para $\alpha$-SMA. (Wakabayashi et al., 2014). Em um estudo em modelo experimental de DRC, o tratamento com 3 doses quinzenais de CTmMO via endovenosa, iniciadas duas semanas após a cirurgia de nefrectomia, resultou na redução da área fibrótica e diminuição da expressão de $\alpha$-SMA, fibronectina, TGF- $\beta$, FSP-1 e Smad 3 (Semedo et al., 2009). Ueno e colaboradores também demonstraram, em modelo de FP induzido por GC que o tratamento com $1 \times 10^{7} \mathrm{CTmMO}$ resultou na diminuição de fatores associados à fibrose, com diminuição da infiltração de miofibroblastos marcados por $\alpha$-SMA e diminuição de colágeno I (Ueno et al., 2013). Em outro estudo em modelo de FP provocada por raspagem do peritôneo, o tratamento com $5 \times 10^{6}$ de CTmMO, administrada via endovenosa 24 horas após raspagem, apresentou redução no nível de expressão de TGF- $\beta$ (Wang et al., 2012).

A via de sinalização do TGF- $\beta$ tem um papel central na fisiopatologia da FP. A sua ligação ao receptor da membrana, ativa uma cascata de sinalização que leva à proliferação de células pró-fibróticas, como miofibroblastos, que também participam na indução da EMT. Além disso, a fosforilação da Smad3 é importante na via de ativação intracitoplasmática desencadeada pelo TGF- $\beta$, pois ao atingir o núcleo são capazes de modular a transcrição de genes envolvidos na fibrose. Duan e colaboradores, ao investigar a via de sinalização do TGF- $\beta / \mathrm{Smad}$, demonstraram que camundongos knockout para o gene Smad3 ao serem expostos a soluções de DP não desenvolviam FP (Duan et al., 2014). No presente estudo, as CTmTA e as VE protegeram a MP contra a 
FP interferindo na via do TGF- $\beta /$ Smad. Foi evidenciado um aumento na expressão dos genes TGF- $\beta$ e Smad3 no grupo FP e os tratamentos com CTmTA e VE diminuíram significativamente a expressão desses genes. Ueno et al demonstraram que houve inibição da sinalização do TGF- $\beta$ em modelo de FP tratado com $1 \times 10^{7}$ CTmMO. Neste mesmo trabalho, a inibição do TGF- $\beta$ foi associado à diminuição da fosforilação do Smad2. O mesmo efeito foi demonstrado em modelo de fibrose cardíaca tratada com meio condicionado (Ueno et al., 2013).

A modulação da via da Smad pode bloquear a FP. A contraposição do TGF- $\beta$ e seus estímulos ocorre com o aumento da Smad7 que, por sua vez, inibe a fosforilação da Smad3, numa alça de feedback negativo (Nie et al., 2007; Guo et al., 2007). Em estudo anterior do nosso laboratório, utilizando o modelo de FP induzido por GC, os animais foram tratados com ácido valpróico, um inibidor das histonas desacetilases, enzimas que regulam a conformação da cromatina e a expressão gênica e possuem atividade antiinflamatória e antifibrótica. Houve redução significativa da expressão da Smad3, em relação ao grupo FP. Por outro lado, os animais tratados com ácido valpróico apresentaram um aumento da expressão peritoneal de fatores antifibróticos como a BMP-7 e Smad7, proteínas que contrarregulam as ações do TGF- $\beta$. (Costalonga et al 2017). Os tratamentos com CTmTA e VE induziram uma maior expressão gênica da Smad7 quando comparados ao grupo FP, com maior expressão apresentada no grupo FP+VE. Guo e colaboradores demonstraram que em ratos que hiperexpressavam Smad7 ocorria o bloqueio da FP induzida por solução de diálise e a inibição da ativação da Smad3 (Guo et al., 2007).

Uma característica dos microambientes cronicamente inflamados é a presença tecidual de macrófagos e linfócitos. No presente estudo, houve um aumento no número 
de macrófagos e linfócitos na MP do grupo FP. Os grupos que receberam as CTmTA ou as VE mostraram uma redução no número de macrófagos e de linfócitos infiltrando a MP. Além disso, os tratamentos limitaram o aumento dos níveis de TNF- $\alpha$, uma citocina pró-inflamatória, induzidos pelo GC no peritôneo.

Estudos têm demonstrado os benefícios da CTm no tratamento da fibrose devido à sua capacidade imunomodulatória. Em um estudo de revisão, Usinier e colaboradores descrevem diversos trabalhos com diferentes modelos de fibrose nos quais, após o tratamento com CTm, houve diminuição da infiltração de monócitos/macrófagos, neutrófilos e linfócitos no tecido. Os autores discutem que provavelmente as CTm induzem a transição de macrófagos para um fenótipo regulatório, limitando a inflamação crônica. Wakabayashi e colaboradores induziram FP por 21 dias com infusão contínua de $8 \%$ de GC. Neste estudo, foi realizado tratamento via IP com $3 \times 10^{7}$ de CTmTA e houve redução dos processos inflamatórios e angiogênicos (Wakabayashi et al., 2014). Em outro estudo, realizado em um modelo de lesão renal aguda, o tratamento com 1 dose de $100 \mu \mathrm{g}$ de VE derivadas de células do cordão umbilical administradas via endovenosa, foi capaz de reduzir o infiltrado de macrófagos (Zou et al., 2014). He e colaboradores, em modelo de DRC tratado com 3 doses de $30 \mu \mathrm{g}$ de VE derivadas de CTmMO, foram capazes de diminuir a infiltração de linfócitos, prevenir a fibrose e melhorar a função renal (He et al., 2012).

As injeções com GC induziram um aumento significativo da densidade capilar peritoneal e da expressão do VEGF. A produção de VEGF é estimulada pelos produtos de degradação da glicose e tem como consequência o aumento do dano citotóxico e das respostas pró-inflamatórias nas células mesoteliais. Além disso, o VEGF parece desempenhar um papel central nos processos que conduzem a neoangiogênese 
peritoneal e declínio funcional (Devoyust et al., 2010). Neste estudo, houve um aumento da expressão de VEGF no grupo com FP e os tratamentos foram capazes de diminuir significantemente a expressão desse gene. A longo prazo, a expressão aumentada do VEGF pode ser detectada no dialisato de pacientes em DP e está associada à diminuição da permeabilidade de pequenos solutos e à perda da UF (Pecoits Filho et al., 2002; Mateijsen et al., 1999). 


\section{RESUMO dos RESULTADOS}

1) As metodologias de isolamento e caracterização das VE derivadas de CTmTA foram estabelecidas com sucesso no nosso laboratório.

2) Os tratamentos com CTmTA e VE foram igualmente eficientes no bloqueio da progressão da FP experimental.

3) As administrações de CTmTA e de VE no modelo de FP bloquearam o aumento do número de miofibroblastos, da expressão de fibronectina e dos fatores envolvidos na FP (TGF- $\beta$ e FSP-1).

4) A expressão gênica de $\operatorname{Smad} 3$, um gene associado a fatores pró-fibróticos foi reduzido no tratamento com CTmTA e VE e a expressão de Smad 7, um gene contrarregulador da via do TGF- $\beta$ foi aumentada, com melhores resultados no grupo tratado com VE.

5) Os tratamentos com CTmTA e VE no modelo de FP apresentaram efeito antiinflamátorio, com a redução da infiltração de macrófagos e linfócitos, além da diminuição da expressão do TNF- $\alpha$, uma citocina pró-inflamatória.

6) As CTmTA e as VE não influenciaram o transporte de glicose pela MP. O grupo com FP tratado com VE apresentou melhora na capacidade de UF.

7) Quanto aos parâmetros relacionados à neoangiogênese, os tratamentos reduziram a expressão do VEGF na MP dos animais com FP, mas não houve diminuição da densidade capilar. 


\section{CONCLUSÃO}

No modelo experimental de fibrose peritoneal, os tratamentos com CTmTA e VE apresentaram efeito anti-inflamatório e foram igualmente eficientes no bloqueio do processo de fibrose peritoneal. O tratamento com VE mostrou melhor capacidade de preservação da função peritoneal, com aumento da capacidade de ultrafiltração. Portanto, os tratamentos com CTmTA ou com VE derivadas de CTmTA apresentam potencial terapêutico e constituem uma nova abordagem, ainda pouco explorada, na prevenção do desenvolvimento da fibrose peritoneal associada à DP. 


\section{REFERÊNCIAS BIBLIOGRÁFICAS}

ABENSUR H, CASTRO MCM. Métodos Dialíticos. Em: Nefrologia, 2 edição, 2005, p. 279.

ABENSUR H. Use of peritoneal dialysis on patients with congestive heart failure. Rev Bras Hipertens. 2008, 162-165.

AGUIRRE AR, ABENSUR H. Fisiologia do transporte de fluidos e solutos através da membrana peritoneal. J. Bras. Nefrol. 2014, 36(1): 74-79.

AKHURST RJ, HATA A. Targeting the TGF $\beta$ signalling pathway in disease. Nat reviews Drug Discov. 2012, 11(10): 790-811.

ALLARIA PM, Giangrande A, Gandini E, Pisoni IB. Continuous ambulatory peritoneal dialysis and sclerosing encapsulating peritonitis: tamoxifen as a new therapeutic agent? J Nephrol. 1999, 12(6):395-397.

ANDALOUSSI EL, MÄGER I, BREAKEFIELD XO, WOOD MJ. Extracellular vesicles: biology and emerging therapeutic opportunities. Nat Rev Drug Discov. 2013, 12(5):347-357.

ARSLAN F(1), LAI RC, SMEETS MB, AKEROYD L, CHOO A, AGUOR EN, TIMMERS L, VAN RIJEN HV, DOEVENDANS PA, PASTERKAMP G, LIM SK, DE KLEIJN DP. Mesenchymal stem cell-derived exosomes increase ATP levels, decrease oxidative stress and activate PI3K/Akt pathway to enhance myocardial viability and prevent adverse remodeling after myocardial ischemia/reperfusion injury. Stem Cell Res. 2013; 10(3):301-312

BARANIAK PR, MCDEVITT TC. Stem cell paracrine actions and tissue regeneration.

Regen Med. 2010, 5(1):121-143. 
BARROS, E, MANFRO, R. C, THOMÉ F.S, GONÇALVES, L.F.S. Diálise no paciente com insuficiência renal crônica: hemodiálise e diálise peritoneal. Em: Nefrologia: Rotinas, diagnósticos e tratamento, 3 edição, 2006, p. 424.

BASSI, EJ, AITA CAM, CÂMARA NOS. Immune regulatory properties of multipotent mesenchymal stromal cells: Where do we stand? World J Stem Cells. 2011, 26; 3(1): $1-8$.

BASSI, EJ, MORAES-VIEIRA PM, MOREIRA-SÁ CS, ALMEIDA DC, VIEIRA LM, CUNHA CS, HIYANE MI, BASSO AS, PACHECO-SILVA A, CÂMARA NO. Immune regulatory properties of allogeneic adipose-derived mesenchymal stem cells in the treatment of experimental autoimmune diabetes. Diabetes. 2012, 61(10): 2534-2545.

BAŞTUĞ F, GÜNDÜZ Z, TÜLPAR S, TORUN YA, AKGÜN H, DÖRTERLER E DÜŞÜNSEL R, POYRAZOĞLU H, BAŞTUĞ O, DURSUN İ. Compare the effects of intravenous and intraperitoneal mesenchymal stem cell transplantation on ultrafiltration failure in a rat model of chronic peritoneal dialysis. Ren Fail. 2014; 36(9): 1428-1435.

BAYATI, M HASHEMITABAR, $\mathrm{R}$ GAZOR, $\mathrm{R}$ NEJATBAKHSH, D BIJANNEJAD. Expression of surface markers and myogenic potential of rat bone marrow-and adipose-derived stem cells: a comparative study. Anat Cell Biol. 2013, 46(2): 113-121.

BÖRGER V, BREMER M, FERRER-TUR R, GOCKELN L, STAMBOULI O, BECIC A, GIEBEL B. Mesenchymal Stem/Stromal Cell-Derived Extracellular Vesicles and Their Potential as Novel Immunomodulatory Therapeutic Agents. Int J Mol Sci. 2017, 18(7): 1450

BORGES FT, REIS LA, SCHOR N. Extracellular vesicles: structure, function, and potential clinical uses in renal diseases. Braz J Med Biol Res. 2013, 46(10):824-830. 
BRADFORD MM. "A rapid and sensitive method for the quantitation of microgram quantities of protein utilizing the principle of protein-dye binding". Anal. Biochem. 1976, 7;72: 248-54.

BRUNO S, GRANGE C, COLLINO F, DEREGIBUS MC, CANTALUPPI V, BIANCONE L, ET AL. Microvesicles derived from mesenchymal stem cells enhance survival in a lethal model of acute kidney injury. PLoS One. 2012, 7(3): 1-11.

BRUNO S, GRANGE C, DEREGIBUS MC, CALOGERO RA, SAVIOZZI S, COLLINO F, ET AL. Mesenchymal stem cell-derived microvesicles protect against acute tubular injury. J Am Soc Nephrol. 2009, 20(5): 1053-1067.

BUNNELL BA, FLAAT M, GAGLIARDI C, PATEL B, RIPOLL C. Adipose-derived stem cells: isolation, expansion and differentiation. Methods. 2008, 45(2):115120.

BYDLOWSKI, SERGIO P.; DEBES, ADRIANA A.; MASELLI, LUCIANA M. F. AND JANZ, FELIPE L.. Biological characteristics of mesenchymal stem cells. Rev. Bras. Hematol. Hemoter. 2009, 1;31: 25-35.

CAPLAN AI, DENNIS JE. Mesenchymal stem cells as trophic mediators. J Cell Biochem. 2006,1;98(5):1076-1084.

CAPLAN AI. Mesenchymal stem cells. J Orthop Res. 1991,9(5):641-650.

CASTRO-MALASPINA H., GAY RE, RESNICK G, KAPOOR N, MEYERS P, CHIARIERI D, MCKENZIE S, BROXMEYER HE, MOORE MA. Characterization of human bone marrow fibroblast colony-forming cells (CFUF) and their progeny. Blood. 1980, 56:289-301 
CAVAGLIERI, R.C Terapia com células tronco derivadas do líquido amniótico humano na nefropatia crônica experimental: é possível bloquear a progressão da doença renal estabelecida? [tese] São Paulo: Faculdade de Medicina da Universidade de São Paulo; 2017.

CESTARI AT, CONTI ML, PRATS JA, SATO JUNIOR H, ABENSUR H. Sclerosing encapsulating peritonitis after peritoneal dialysis. J Bras Nefrol. 2013;35(1): 65-68.

CLARK CP, VANDERPOOL D, PRESKITT JT. The response of retroperitoneal fibrosis to tamoxifen. Surgery. 1991, 109(4):502-506.

CORDEIRO AC, CARRERO JJ, QURESHI AR, CUNHA RF, LINDHOLM B, CASTRO ID, NORONHA IL. Study of the incidence of dialysis in São Paulo, the largest Brazilian city. Clinics (Sao Paulo). 2013, 68(6): 760-765.

COSTALONGA EC, DE FREITAS LJ, ARAGONE DDSP, SILVA FMO, NORONHA IL. Anti-fibrotic effects of valproic acid in experimental peritoneal fibrosis. PLoS One. 2017, 5;12(9): 1-17.

COUSER WG, REMUZZI G, MENDIS S, TONELLI M. The contribution of chronic kidney disease to the global burden of major noncommunicable diseases. Kidney Int. 2011, 80(12): 1258-1270.

DE LIMA SM, OTONI A, SABINO ADE P, DUSSE LM, GOMES KB, PINTO SW, MARINHO MA, RIOS DR Inflammation, neoangiogenesis and fibrosis in peritoneal dialysis. Clin Chim Acta. 2013, 5;421:46-50.

DELLÊ H, ROCHA JR, CAVAGLIERI RC, VIEIRA JM JR, MALHEIROS DM, NORONHA IL. Antifibrotic effect of tamoxifen in a model of progressive renal disease. J Am Soc Nephrol. 2012, 23(1): 37-48. 
DEVUYST O, MARGETTS PJ, TOPLEY N. The pathophysiology of the peritoneal membrane. J Am Soc Nephrol. 2010; 21(7): 1077-1085.

DEVUYST O, NI J. Aquaporin-1 in the peritoneal membrane: Implications for water transport across capillaries and peritoneal dialysis.Biochim Biophys Acta. 2006, 1758(8):1078-1084.

DOMINICI M, LE BLANC K, MUELLER I, SLAPER-CORTENBACH I, MARINI F, KRAUSE D, DEANS R, KEATING A, PROCKOP DJ, HORWITZ E. Minimal criteria for defining multipotent mesenchymal stromal cells. The International Society for Cellular Therapy position statement. Cytotherapy. 2006, 8(4): 315-317.

DUAN WJ, YU X, HUANG XR, YU JW, LAN HY. Opposing roles for Smad2 and Smad3 in peritoneal fibrosis in vivo and in vitro. Am J Pathol. 2014, 184(8): 2275-2284.

EL NAHAS M. The global challenge of chronic kidney disease. Kidney Int. 2005, 68(6): 2918-2929.

FENG J, ZHAO L, DENG H, WEI M, LI J, XU K. Immune tolerance of amniotic fluid stem cell-induced rat kidney graft and influences on oxidative stress. Transplant Proc. 2013, 45(9):3394-3401.

FINKELSTEIN FO. Structural requirements for a successful chronic peritoneal dialysis program. Kidney Int Suppl. 2006, (103):S118-21.

FORTIER LA. Stem cells: classifications, controversies, and clinical applications. Vet Surg. 2005, 34(5): 415-423. 
FRANQUESA M, HOOGDUIJN MJ, RIPOLL E, LUK F, SALIH M, BETJES MG, TORRAS J, BAAN CC, GRINYÓ JM, MERINO AM. Update on controls for isolation and quantification methodology of extracellular vesicles derived from adipose tissue mesenchymal stem cells. Front Immunol. 2014, 21;5: 525 .

FRIEDENSTEIN AJ, CHAILAKHJAN RK, LALYKINA KS. The development of fibroblast colonies in monolayer cultures of guinea-pig bone marrow and spleen cells. Cell Tissue Kinet. 1970, 3(4): 393-403.

GATTI S, BRUNO S, DEREGIBUS MC, SORDI A, CANTALUPPI V, TETTA C, et al. Microvesicles derived from human adult mesenchymal stem cells protect against ischaemia-reperfusion-induced acute and chronic kidney injury. Nephrol Dial Transplant. 2011, 26 (5): 1474-1483.

GHAFFARI A, KALANTAR-ZADEH K, LEE J, MADDUX F, MORAN J, NISSENSON A. PD First: peritoneal dialysis as the default transition to dialysis therapy. Semin Dial. 2013, 26(6): 706-713

GIMBLE JM, KATZ AJ, BUNNELL BA. Adipose-derived stem cells for regenerative medicine. Circ Res. 2007, 100(9): 1249-1260.

GUAN K, ROHWEDEL J, WOBUS AM. Embryonic stem cell differentiation models: cardiogenesis, myogenesis, neurogenesis, epithelial and vascular smooth muscle cell differentiation in vitro. Cytotechnology. 1999, 30(1-3): 211-226.

GUEST S. Tamoxifen therapy for encapsulating peritoneal sclerosis: mechanism of action and update on clinical experiences. Perit Dial Int. 2009, 29(3): 252255.

GUO H, LEUNG JC, LAM MF, CHAN LY, TSANG AW, LAN HY, ET AL. Smad7 transgene attenuates peritoneal fibrosis in uremic rats treated with peritoneal dialysis. J Am Soc Nephrol. 2007, 18(10): 2689-2703. 
GYÖRGY B, SZABÓ TG, PÁSZTÓI M, PÁL Z, MISJÁK P, ARADI B, VALÉRIA LÁSZLÓ, ÉVA PÁLLINGER, ERNA PAP, ÁGNES KITTEL, GYÖRGY NAGY, ANDRÁS FALUS, EDIT I. BUZÁS. Membrane vesicles, current state-of-the-art: emerging role of extracellular vesicles. Cell Mol Life Sci. 2011, 68(16): 2667-2688.

HAKAN ORBAY, MORIKUNI TOBITA, HIROSHI MIZUNO. Mesenchymal stem cells isolated from adipose and other tissues: basic biological properties and clinical applications. Stem Cells Int. 2012, 2012: 1-9.

HEIJNEN HF, SCHIEL AE, FIJNHEER R, GEUZE HJ, SIXMA JJ. Activated platelets release two types of membrane vesicles. Blood. 1999, 1;94(11):3791-3799.

HEJ, WANG Y, SUN S, YU M, WANG C, PEI X, ZHU B, WU J, ZHAO W. Bone marrow stem cells-derived microvesicles protect against renal injury in the mouse remnant kidney model. Nephrology (Carlton). 2012, 17(5):493500.

HELDRING N, MÄGER I, WOOD MJ, LE BLANC K, ANDALOUSSI SE. Therapeutic Potential of Multipotent Mesenchymal Stromal Cells and Their Extracellular Vesicles. Hum Gene Ther. 2015, 26(8):506-517

HOFF CM. Experimental animal models of encapsulating peritoneal sclerosis. Perit Dial Int. 2005, 4:S57-66.

K/DOQI Clinical practice guidelines for chronic kidney disease: evaluation, classification, and stratification. Am J Kidney Dis. 2002, 39(2):S1-266.

KORDELAS L, REBMANN V, LUDWIG AK, RADTKE S, RUESING J, DOEPPNER TR, EPPLE M4, HORN PA, BEELEN DW, GIEBEL B. MSCderived exosomes: a novel tool to treat therapy-refractory graft-versus-host disease. Leukemia. 2014, 28(4):970-973. 
KREDIET RT, LOPES BARRETO D, STRUIJK DG. Can Free Water Transport Be Used as a Clinical Parameter for Peritoneal Fibrosis in Long-Term PD Patients? Perit Dial Int. 2016, 36(2):124-128.

KREDIET RT. Evaluation of peritoneal membrane integrity. J Nephrol. 1997, 10(5): 238-244.

KUMAR VA, SIDELL MA, JONES JP, VONESH EF. Survival of propensity matched incident peritoneal and hemodialysis patients in a United States health care system. Kidney Int. 2014, 86(5): 1016-1022.

LAI KN, Leung JC. Inflammation in peritoneal dialysis. Nephron Clin Pract. 2010, 116(1): c11-18.

LAMIERE N, VANHOLDER R, VAN BIESEN W. Acute Renal Failure. Lancet, $2005 ; 365: 417-430$.

LAURA FRESE, PETRA E. DIJKMAN, SIMON P. HOERSTRUP. Adipose tissue derived stem cells in regenerative medicine. Transfus Med Hemother. 2016, 43(4): 268-274.

LOTFY A, SALAMA M, ZAHRAN F, JONES E, BADAWY A, SOBH M. Characterization ofmesenchymal stem cells derived from rat bone marrow and adipose tissue: a comparative study. Int J Stem Cells. 2014, 7(2): $135-142$.

LÖTVALL J. Minimal experimental requirements for definition of extracellular vesicles and their functions: a position statement from the International Society for Extracellular Vesicles. J Extracell Vesicles. 2014, 22;3: 26913-26919.

LOUREIRO J, AGUILERA A, SELGAS R, SANDOVAL P, ALBAR-VIZCAINO P, PEREZ-LOZANO ML, ET AL. Blocking TGF-beta1 protects the peritoneal membrane from dialysate-induced damage. J Am Soc Nephrol. 2011, 22(9): 1682-1695. 
LOUREIRO J, SANDOVAL P, DEL PESO G, GÓNZALEZ-MATEO G, FERNÁNDEZ-MILLARA V, SANTAMARIA B, BAJO MA. Tamoxifen ameliorates peritoneal membrane damage by blocking mesothelial to mesenchymal transition in peritoneal dialysis. PLoS One. 2013, 23;8(4): 1-15

LUKOWSKY LR, MEHROTRA R, KHEIFETS L, ARAH OA, NISSENSON AR, KALANTAR-ZADEH K. Comparing mortality of peritoneal and hemodialysis patients in the first 2 years of dialysis therapy: a marginal structural model analysis. Clin J Am Soc Nephrol. 2013, 8(4):619-628

MA S, XIE N, LI W, YUAN B, SHI Y, WANG Y. Immunobiology of mesenchymal stem cells. Cell Death Differ. 2014, 21(2): 216-225.

MAHMOOD A1, LU D, LU M, CHOPP M. Treatment of traumatic brain injury in adult rats with intravenous administration of human bone marrow stromal cells. Neurosurgery. 2003, 53(3):697-702

MAKRIDAKIS M, ROUBELAKIS MG, VLAHOU A. Stem cells: insights into the secretome. Biochim Biophys Acta. 2013, 1834(11): 2380-2384.

MASSAGUÉ J, SEOANE J, WOTTON D. Smad transcriptional factors. Genes Dev. 2005, 1;19(23): 2783-2810.

MASSAGUÉ J. TGFß signaling in context. Nat Rev Mol Cell Biol. 2012, 13(10): 616630.

MATEIJSEN MA, VAN DER WAL AC, HENDRIKS PM, ZWEERS MM, MULDER J, STRUIJK DG, et al. Vascular and interstitial changes in the peritoneum of CAPD patients with peritoneal sclerosis. Perit Dial Int. 1999, 19(6): 517-525.

MATHIVANAN S, LIM JW, TAURO BJ, JI H, MORITZ RL, SIMPSON RJ. Proteomics analysis of A33 immunoaffinity-purified exosomes released from 
the human colon tumor cell line LIM1215 reveals a tissue-specific protein signature. Mol Cell Proteomics. 2010, 9(2): 197-208.

MINGUELL JJ, LORINO R, LASALA GP. Myocardial implantation of a combination stem cell product by using a transendocardial MYOSTAR injection catheter: A technical assessment. Acute Card Care. 2011, 13(1): 4042.

MITU G, HIRSCHBERG R. Bone morphogenic protein-7 in chronic kidney disease. Frontiers in Bioscience. 2008; 13: 4726-4739,

MIYAHARA Y1, NAGAYA N, KATAOKA M, YANAGAWA B, TANAKA K, HAO H, ISHINO K, ISHIDA H, SHIMIZU T, KANGAWA K, SANO S, OKANO T, KITAMURA S, MORI H. Monolayered mesenchymal stem cells repair scarred myocardium after myocardial infarction. Nat Med. 2006, 12(4): 459465.

MOINUDDIN Z, SUMMERS A, VAN DELLEN D, AUGUSTINE T, HERRICK SE. Encapsulating peritoneal sclerosis-a rare but devastating peritoneal disease. Front Physiol. 2015, 5;5:470.

MORELLE J, SOW A, HAUTEM N, BOUZIN C, CROTT R, DEVUYST O, ET AL. Interstitial Fibrosis Restricts Osmotic Water Transport in Encapsulating Peritoneal Sclerosis. J Am Soc Nephrol. 2015, 26(10): 2521-2533.

MUÑOZ-ESPÍN D, SERRANO M. Cellular senescence: from physiology to pathology. Nat Rev Mol Cell Biol. 2014, 15(7): 482-496.

MUÑOZ-ESPÍN D, SERRANO M. Cellular senescence: from physiology to pathology. Nat Rev Mol Cell Biol. 2014, 15(7): 482-496. 
MURPHY J M, FINK D J, HUNZIKER E B, BARRY F P. Stem cell therapy in a caprine model of osteoarthritis. Arthritis Rheum. 2003, 48(12): 3464-3474.

MURPHY MB, MONCIVAIS K, CAPLAN AI. Mesenchymal stem cells: environmentally responsive therapeutics for regenerative medicine. Exp Mol Med. 2013, 15;45: 54.

NASSAR W, EL-ANSARY M, SABRY D, MOSTAFA M A, FAYAD T, KOTB E, TEMRAZ M, SAAD A, ESSA W, AND ADEL H. Umbilical cord mesenchymal stem cells derived extracellular vesicles can safely ameliorate the progression of chronic kidney diseases. Biomater Res. 2016, 5;20: 21.

NAVARRO-ALVAREZ N, SOTO-GUTIERREZ A, YUASA T, YAMATSUJI T, SHIRAKAWA Y, NAGASAKA T, SUN SD, JAVED MS, TANAKA N, KOBAYASHI N. Long-term culture of Japanese human embryonic stem cells in feeder-free conditions. Cell Transplant. 2008, 17 (1-2): 27-33.

NI J, CNOPS Y, DEBAIX H, BOISDÉ I, VERBAVATZ JM, DEVUYST O. Functional and molecular characterization of a peritoneal dialysis model in the C57BL/6J mouse. Kidney Int. 2005, 67(5): 2021-2031.

NIE J, HAO W, DOU $\mathrm{X}$, WANG $\mathrm{X}$, LUO $\mathrm{N}$, LAN HY, YU X. Effects of Smad7 overexpression on peritoneal inflammation in a rat peritoneal dialysis model. Perit Dial Int. 2007, 27(5):580-588.

NONG K, WANG W, NIU X, HU B, MA C, BAI Y, HU B, AI K. Hepatoprotective effect of exosomes from human-induced pluripotent stem cell-derived mesenchymal stromal cells against hepatic ischemia-reperfusion injury in rats. Cytotherapy. 2016, 18(12): 1548-1559.

NORONHA IL, SCHOR N, COELHO SN, JORGETTI V, ROMÃO JÚNIOR JE, ZATZ R, BURDMANN EA. Nephrology, dialysis and transplantation in Brazil. Nephrol Dial Transplant. 1997, 12(11): 2234-2243. 
ODORICO JS, KAUFMAN DS, THOMSON JA. Multilineage differentiation from human embryonic stem cell lines. Stem Cells. 2001, 19(3): 193-204.

PAREKKADAN B, MILWID JM. Mesenchymal stem cells as therapeutics. Annu Rev Biomed Eng. 2010, 15;12: 87-117.

PECOITS- FILHO R, ARAUJO MRT, LINDHOLM B, STENVINKEL P, ABENSUR H, ROMÃO JR JR, MARCONDES M, OLIVEIRA AHF, NORONHA IL. Plasma and dialysate IL-6 and VEGF concentrations are associated with high peritoneal solute transport rate. Nephrol. Dial. Transplant. 2002, 17 (8): 1480-1486.

PHINNEYDG, PITTENGER MF. MSC-Derived Exosomes for Cell-Free Therapy. Stem Cells. 2017, 35(4): 851-858.

PLETINCK A, VANHOLDER R, VEYS N, VAN BIESESW. Protecting the peritoneal membrane: factors beyond peritoneal dialysis solutions. Nat Rev Nephrol. 2012, 8(9): 542-550.

PRESTON SL, ALISON MR, FORBES SJ, DIREKZE NC, POULSOM R, WRIGHT NA. The new stem cell biology: something for everyone. Mol Pathol. 2003, 56(2): 86-96.

PROCKOP DJ. Repair of tissues by adult stem/progenitor cells (MSCs): controversies, myths, and changing paradigms. Mol Ther. 2009, 17(6):939-946.

RAMASWAMY Y, LIM K S, ZREIQAT H, LU Z. Stem Cells for Bone Regeneration: Role of Trophic Factors. Advanced Techniques in Bone Regeneration 2016, cap. 15 p. $357-374$.

RANI S, RYAN A, GRIFFIN MD, RITTER T. Mesenchymal Stem Cell-derived Extracellular Vesicles: Toward Cell-free Therapeutic Applications. Molecular Therapy 2015, 23(5), 812-823. 
RAPOSO G, STOORVOGEL W. Extracellular vesicles: exosomes, microvesicles, and friends. J Cell Biol. 2013, 18;200(4):373-383.

RAPOSO G, NIJMAN HW, STOORVOGEL W, LIEJENDEKKER R, HARDING CV, MELIEF CJ, GEUZE HJ. B lymphocytes secrete antigen-presenting vesicles. J Exp Med. 1996, 1;183(3): 1161-1172.

REIS LA, BORGES FT, SIMOES MJ, BORGES AA, SINIGAGLIA-COIMBRA R, SCHOR N. Bone marrow-derived mesenchymal stem cells repaired but did not prevent gentamicin-induced acute kidney injury through paracrine effects in rats. PLoS ONE. 2012, 7(9): 1-11.

RIPPE B, SIMONSEN O, STELIN G. Clinical implications of a three-pore model of peritoneal transport. Adv Perit Dial. 1991, 7:3-9.

RIPPON HJ, BISHOP AE. Embryonic stem cells. Cell Prolif. 2004, 37(1): 23-34.

SAMPIMON DE, BARRETO DL, COESTER AM, STRUIJK DG, KREDIET RT. The value of osmotic conductance and free water transport in the prediction of encapsulating peritoneal sclerosis. Adv Perit Dial. 2014, 30:21-26.

SCHENA FP, ABBATTISTA MR. Stem cells: reparative medicine and nephrology. J Nephrol. 2003, 16;7:S1-5.

SCHILTE MN, CELIE JW, WEE PM, BEELEN RH, VAN DEN BORN J. Factors contributing to peritoneal tissue remodeling in peritoneal dialysis. Perit Dial Int. 2009, 29(6):605-617.

SEMEDO P, CORREA-COSTA M, ANTONIO CENEDEZE M, MARIA AVANCINI COSTA MALHEIROS D, ANTONIA DOS REIS M, SHIMIZU MH SEGURO AC, PACHECO-SILVA A, SARAIVA CAMARA NO. Mesenchymal stem cells attenuate renal fibrosis through immune 
modulation and remodeling properties in a rat remnant kidney model. Stem Cells. 2009, 27(12): 3063-3073.

SHI M, LIU ZW, WANG FS. Immunomodulatory properties and therapeutic application of mesenchymal stem cells. Clin Exp Immunol. 2011, 164(1): 1-8.

SOCIEDADE BRASILEIRA DE NEFROLOGIA - SBN - Disponível em https://sbn.org.br/.

SPEES JL, LEE RH, GREGORY CA. Mechanisms of mesenchymal stem/stromal cell function. Stem Cell Res Ther. 2016, 31;7(1):125.

SUGA H, TERAOKA S, OTA K, KOMEMUSHI S, FURUTANI S, YAMAUCHI S, MARGOLIN S Preventive effect of pirfenidone against experimental sclerosing peritonitis in rats. H Exp Toxicol Pathol. 1995, 47(4): 287-291.

SUN L, XU R, SUN X, DUAN Y, HAN Y, ZHAO Y, QIAN H, ZHU W, XU W. Safety evaluation of exosomesderived from human umbilical cord mesenchymal stromal cell. Cytotherapy. 2016,18(3): 413-422.

TERMORSHUIZEN F, KOREVAAR JC, DEKKER FW, VAN MANEN JG, BOESCHOTEN EW, KREDIET RT; NECOSAD Study Group. The relative importance of residual renal function compared with peritoneal clearance for patient survival and quality of life: an analysis of the Netherlands Cooperative Study on the Adequacy of Dialysis (NECOSAD)-2. Am J Kidney Dis. 2003, 41(6): 1293-1302.

THÉRY C, AMIGORENA S, RAPOSO G, CLAYTON A. Isolation and characterization of exosomes from cell culture supernatants and biological fluids. Curr Protoc Cell Biol. 2006, cap. 3; 30(1).

THÉRY C. Exosome secretion: molecular mechanisms and roles in immune responses. Traffic. 2011, 12(12): 1659-1668. 
TOPLEY N, LIBEREK T, DAVENPORT A, LI FK, FEAR H, WILLIAMS JD. Activation of inflammation and leukocyte recruitment into the peritoneal cavity. Kidney Int. Suppl. 1996, 56:S17-21.

UENO T, NAKASHIMA A, DOI S, KAWAMOTO T, HONDA K, YOKOYAMA Y, DOI T, HIGASHI Y, YORIOKA N, KATO Y, KOHNO N, MASAKI T. Mesenchymal stem cells ameliorate experimental peritoneal fibrosis by suppressing inflammation and inhibiting TGF- $\beta 1$ signaling. Kidney Int. 2013, 84(2): 297-307.

USUNIER B, BENDERITTER M, TAMARAT R, CHAPEL A. Management of fibrosis: the mesenchymal stromal cells breakthrough. Stem Cells Int. 2014, 2014:340257.

VAN BAAL JO, VAN DE VIJVER KK, NIEUWLAND R, VAN NOORDEN CJ, VAN DRIEL WJ, STURK A, et al. The histophysiology and pathophysiology of the peritoneum. Tissue Cell. 2017; 49(1): 95-105.

VERENA BÖRGER, MICHEL BREMER, RITA FERRER-TUR, LENA GOCKELN, OUMAIMA STAMBOULI, AMINA BECIC, BERND GIEBEL. Mesenchymal Stem/Stromal Cell-Derived Extracellular Vesicles and Their Potential as Novel Immunomodulatory Therapeutic Agents. Int J Mol Sci. 2017, 6;18(7): 1450-1469.

VERFAILLIE CM. Adult stem cells: assessing the case for pluripotency. Trends Cell Biol. 2002, 12(11):502-508.

WAKABAYASHI K1, HAMADA C, KANDA R, NAKANO T, IO H, HORIKOSHI S, TOMINO Y. Adipose-derived mesenchymal stem cells transplantation facilitate experimental peritoneal fibrosis repair by suppressing epithelialmesenchymal transition. J Nephrol. 2014, 27(5): 507-514 
WAKABAYASHI K1, HAMADA C, KANDA R, NAKANO T, IO H, HORIKOSHI S, TOMINO Y. Adipose-derived mesenchymal stem cells transplantation facilitate experimental peritoneal fibrosis repair by suppressing epithelialmesenchymal transition. J Nephrol. 2014, 27(5): 507-14

WANG N, LI Q, ZHANG L, LIN H, HU J, LI D, SHI S, CUI S, ZHOU J, JI J, WAN J, CAI G, CHEN X. Mesenchymal stem cells attenuate peritoneal injury through secretion of TSG-6. PLoS One. 2012, 7(8).

WANG J, LIU S, LI H, SUN J, ZHANG S, XU X, LIU Y, WANG Y, MIAO L. A reviewof rodent models of peritoneal dialysis and its complications. Send to Int Urol Nephrol. 2015, 47(1): 209-215.

WILLIAMS JD, CRAIG KJ, TOPLEY N, VON RUHLAND C, FALLON M, NEWMAN GR, et al. Morphologic changes in the peritoneal membrane of patients with renal disease. J. Am. Soc. Nephrol. 2002, 13(2): 470-479.

WITOWSKI J, WISNIEWSKA J, KORYBALSKA K, BENDER TO, BREBOROWICZ A, GAHL GM, et al. Prolonged exposure to glucose degradation products impairs viability and function of human peritoneal mesothelial cells. J. Am. Soc. Nephrol. 2001, 12(11): 2434-2441

YÁÑEZ-MÓ M, LARA-PEZZI E, SELGAS R, RAMÍREZ-HUESCA M, DOMÍNGUEZ-JIMÉNEZ C, JIMÉNEZ-HEFFERNAN JA, ET AL. Peritoneal dialysis and epithelial-to-mesenchymal transition of mesothelial cells. N Engl J Med. 2003, 348(5): 403-413.

YÁÑEZ-MÓ M, SILJANDER PR, ANDREU Z, ZAVEC AB, BORRÀS FE, BUZAS EI, BUZAS K1, CASAL E, ET AL DE WEVER O. Biological properties of extracellular vesicles and their physiological functions. J Extracell Vesicles. 2015, 14;4:27066. 
YARAK S, OKAMOTO O K. Células-tronco derivadas de tecido adiposo humano: desafios atuais e perspectivas clínicas. An. Bras. Dermatol. 2010, 85(5).

YOSHIO Y, MIYAZAKI M, ABE K, NISHINO T, FURUSU A, MIZUTA Y, HARADA T, OZONO Y, KOJI T, KOHNO S. TNP-470, an angiogenesis inhibitor, suppresses the progression of peritoneal fibrosis in mouse experimental model. Kidney Int. 2004, 66(4): 1677-1685.

YOUNG HE, BLACK AC JR. Adult stem cells. Anat Rec A Discov Mol Cell Evol Biol. 2004, 276(1): 75-102.

YU B, ZHANG X, LI X. Exosomes derived from mesenchymal stem cells. Int J Mol Sci. 2014,$7 ; 15(3):$ 4142-4157.

YU MA, SHIN KS, KIM JH, KIM YI, CHUNG SS, PARK SH, KIM YL, KANG DH. HGF and BMP-7 ameliorate high glucose-induced epithelial-to-mesenchymal transition of peritoneal mesothelium. J Am Soc Nephrol. 2009, 20(3): 567581.

ZABOROWSKI MP, BALAJ L, BREAKEFIELD XO, LAI CP. Extracellular Vesicles: Composition, Biological Relevance, and Methods of Study. Bioscience. 2015, 1;65(8): 783-797.

ZACHAR L, BAČENKOVÁ D, ROSOCHA J. Activation, homing, and role of the mesenchymal stem cells in the inflammatory environment. J Inflamm Res. 2016, 15;9: 231-240.

ZAREIE M, DE VRIESE AS, HEKKING LH, TER WEE PM, SCHALKWIJK CG, DRIESPRONG BA, SCHADEE-EESTERMANS IL, BEELEN RH, LAMEIRE N, VAN DEN BORN J. Immunopathological changes in a uraemic rat model for peritoneal dialysis. Nephrol Dial Transplant. 2005, 20(7): 13501361. 
ZHAO Y, SUN X, CAO W, MA J, SUN L, QIAN H, ZHU W, XU W. Exosomes Derived from Human Umbilical Cord Mesenchymal Stem Cells Relieve Acute Myocardial Ischemic Injury. Stem Cells Int. 2015, 2015;761643.

ZHOU Q, BAJO MA, DEL PESO G, YU X, SELGAS R. Preventing peritoneal membrane fibrosis in peritoneal dialysis patients. Kidney Int. 2016, 90(3): 515-524.

ZHOU Y, XU H, XU W, WANG B, WU H, TAO Y, ZHANG B, WANG M, MAO F, YAN Y, GAO S, GU H, ZHU W. QIAN H. Exosomes released by human umbilical cord mesenchymal stem cells protect against cisplatin-induced renal oxidative stressand apoptosis in vivo and in vitro. Stem Cell Res Ther. 2013, $25 ; 4(2): 34$.

ZOU X, ZHANG G, CHENG Z, YIN D, DU T, JU G, MIAO S, LIU G, LU M, ZHU Y. Microvesicles derived from human Wharton's Jelly mesenchymal stromal cells ameliorate renal ischemia-reperfusion injury in rats by suppressing CX3CL1. Stem Cell Res Ther. 2014, 19;5(2): 40.

ZUTTION MSSR, WENCESLAU CV, LEMOS PA, TAKIMURA C, KERKIS I. Células-tronco de tecido adiposo e a importância da padronização de um modelo animal para experimentação pré-clínica. Rev. Bras. Cardiol. Invasiva 2013, 21(3). 